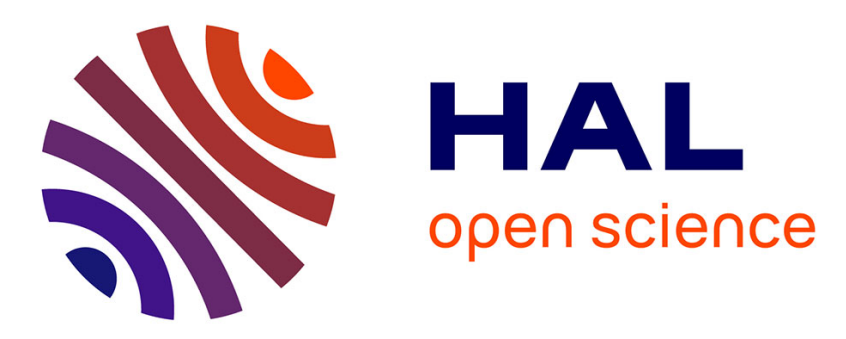

\title{
Designing functional polyoxometalate-based ionic liquid crystals and ionic liquids
}

\author{
Yohan Martinetto, Bruce Pegot, Catherine Roch-Marchal, Betty Cottyn \\ Boitte, Sébastien Floquet
}

\section{- To cite this version:}

Yohan Martinetto, Bruce Pegot, Catherine Roch-Marchal, Betty Cottyn Boitte, Sébastien Floquet. Designing functional polyoxometalate-based ionic liquid crystals and ionic liquids. European Journal of Inorganic Chemistry, 2019, 2020 (3), pp.228-247. 10.1002/ejic.201900990 · hal-02621781

\section{HAL Id: hal-02621781 \\ https://hal.inrae.fr/hal-02621781}

Submitted on 26 May 2020

HAL is a multi-disciplinary open access archive for the deposit and dissemination of scientific research documents, whether they are published or not. The documents may come from teaching and research institutions in France or abroad, or from public or private research centers.
L'archive ouverte pluridisciplinaire HAL, est destinée au dépôt et à la diffusion de documents scientifiques de niveau recherche, publiés ou non, émanant des établissements d'enseignement et de recherche français ou étrangers, des laboratoires publics ou privés. 


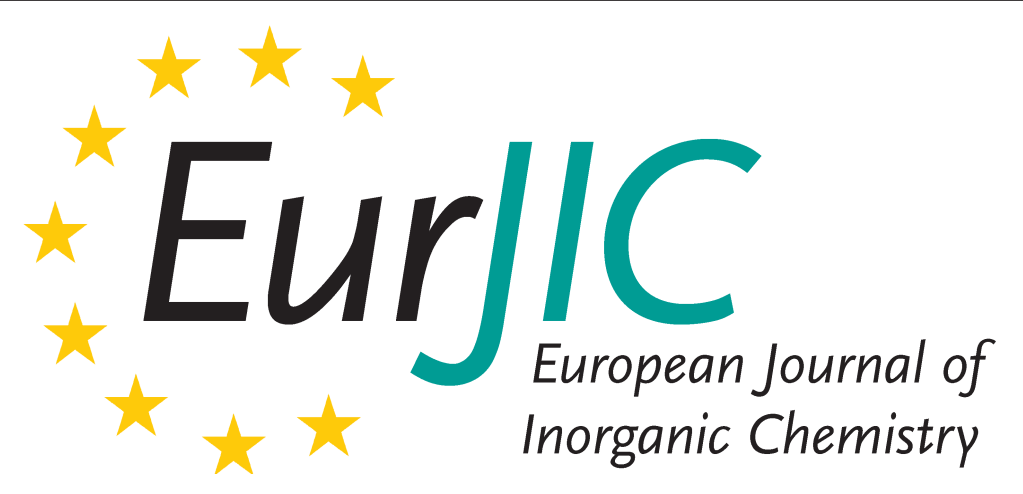

\section{Accepted Article}

Title: Designing Functional Polyoxometalate-based ionic liquid crystals and ionic liquids.

Authors: Yohan Martinetto, Bruce Pégot, Catherine Roch-Marchal, Betty Cottyn-Boitte, and Sebastien Floquet

This manuscript has been accepted after peer review and appears as an Accepted Article online prior to editing, proofing, and formal publication of the final Version of Record (VoR). This work is currently citable by using the Digital Object Identifier (DOI) given below. The VoR will be published online in Early View as soon as possible and may be different to this Accepted Article as a result of editing. Readers should obtain the VoR from the journal website shown below when it is published to ensure accuracy of information. The authors are responsible for the content of this Accepted Article.

To be cited as: Eur. J. Inorg. Chem. 10.1002/ejic.201900990

Link to VoR: http://dx.doi.org/10.1002/ejic.201900990 


\title{
Designing Functional Polyoxometalate-based ionic liquid crystals and ionic liquids.
}

\author{
Yohan Martinetto, ${ }^{\mathrm{a}, \mathrm{b}}$ Bruce Pégot, ${ }^{\mathrm{a}}$ Catherine Roch-Marchal, ${ }^{\mathrm{a}}$ Betty Cottyn-Boitte, ${ }^{\mathrm{b}}$ and \\ Sébastien Floquet. ${ }^{\mathrm{a}, *}$
}

\begin{abstract}
a) M. Y.Martinetto, Dr B. Pégot, Dr C. Roch-Marchal, Dr S. Floquet
Institut Lavoisier de Versailles, UMR 8180, Université de Versailles St-Quentin en Yvelines, Université Paris-Saclay, 45 Avenue des Etats-Unis, 78035 Versailles, France.

Corresponding author: sebastien.floquet@uvsq.fr

b) M. Y.Martinetto, Dr B. Cottyn-Boitte.

Institut Jean-Pierre Bourgin, INRA, Agro Paris Tech, CNRS, Université Paris Saclay, 78000 Versailles, France.
\end{abstract}

\begin{abstract}
.
Polyoxometalate (POM) compounds constitute a wide family rich of more than several thousand inorganic compounds which can be finely tuned at the molecular level. Considering their high diversities in structures and properties, the incorporation of such inorganic components into liquid crystalline phases or ionic liquid phases is particularly relevant for the elaboration of functional materials. By adjusting the molecular structures of the anions and the nature of the counter cations, many authors designed different types of mesophases sometimes with application in optoelectronics, or true POM-based Ionic liquids (POM-ILs with melting temperature below $100{ }^{\circ} \mathrm{C}$ ). The latter turn out to be highly interesting for various applications in catalysis, depollution, or protection of the historical heritage. This review focuses on the recent developments in these organic/inorganic hybrid materials, POMbased Ionic liquid crystal and POM-ILs and their applications.
\end{abstract}

Keywords: Polyoxometalate; Liquid Crystal; Ionic Liquid; Cluster; Hybrid; Catalysis

Key Topic : Polyoxometalates-based soft matter. 
Yohan Martinetto was born in France in 1994. He received his Technical University degree in chemistry, mathematics and physics in 2014, his chemistry Bachelor's degree from University of Grenoble-Alpes (France) in 2015, and a Master's degree "Green and Sustainable Chemistry" from the University of Savoie Mont-Blanc (France) in 2017. He currently works towards a Ph.D. degree of University of Paris-Saclay, under the supervision of Dr. Sebastien Floquet. His work focuses on the sustainable applications and development of new Polyoxometalate-based Ionic Liquids, notably for catalysis.

Dr.Bruce Pégot is a lecturer. He carried out his Ph.D. on microwave assisted synthesis for ionic liquids (University Paris-Sud XI of Orsay, France) in 2005. Subsequently, he joined the group of Prof. N. Gathergood (Dublin City University, Ireland) for postdoctoral research in biodegradable ionic liquids, and has completed a year of research assistant (University Paris- XII of Creteil, France) in organometallic chemistry. In 2007, he joined the Institut Lavoisier of Versailles (University of Versailles, Paris-Saclay University) and his research activities are now focused on fluorine chemistry, ionic liquid chemistry and eco-friendly chemistry.

After an initial formation of chemical engineer, Dr. Catherine RochMarchal started an academic career in 1989 with an internship with Pr. J. Fraissard (Paris VI) on ${ }^{129}$ Xe NMR for zeolithe characterization. Then she discovered the fascinating properties of polyoxometalates and their applications for catalysis during her Ph.D. under the supervision of Pr. Hervé (Paris VI). In 1992, she joined the team of Y. Ben Taarit at IRC in Lyon for a post-doctoral position and studied the synthesis and characterizations of VAPO. In 1993, she was appointed
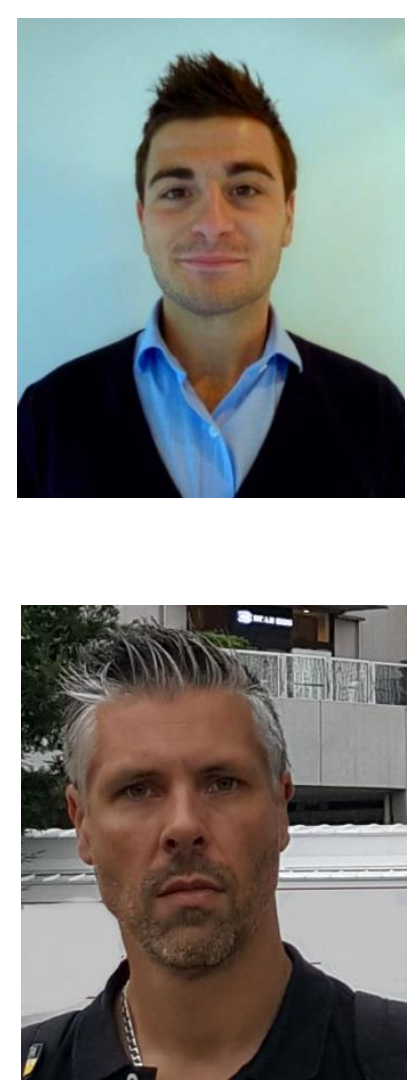
assistant professor at the University of Versailles. She synthesized and studied POMs for their catalytic applications but especially focused on the characterization of the effective active phases by different spectroscopic methods. From the beginning of the synthesis of MIL-101 by Ferey's team at the Lavoisier Institute, she also studied the incorporation of POMs inside different Metal Organic Frameworks (MOFs).

Dr Betty Cottyn-Boitte is a senior scientist. She carried out her Ph.D. on the indazoles and the inhibition of NO-synthases (Versailles University, France) in 2007. Then, she joined the group of Prof. R. Griffin (NICR, Newcastle, UK) for postdoctoral research in the inhibition of ERK5 for the treatment of prostate cancer. In 2009, she joined Institut Jean Pierre Bourgin at INRA of Versailles, France. After a background in medicinal chemistry, her research topics mainly focus on lignocellulose biorefinery and lignin catalysis for a better use of lignocellulosic biomass, ionic liquid

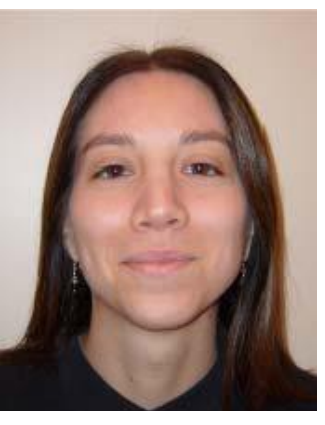
chemistry and eco-friendly chemistry. 
Dr Sébastien Floquet was born in Reims, France. He pursued doctoral studies in the domain of spin crossover of ferric complexes in University of Paris XI (Orsay) and received his Ph.D. degree in 2001 under the supervision of Dr M.-L. Boillot. After two years as post-doctoral researcher in Geneva in the group of Prof. C. Piguet, where he studied helicates of lanthanides, he was then appointed assistant Professor in 2003, then associate professor in 2009 at the Institut Lavoisier of Versailles, University of Versailles. He is coauthor of 80 publications. He was awarded as junior member of the Institut Universitaire de France in 2014 and received junior prize of

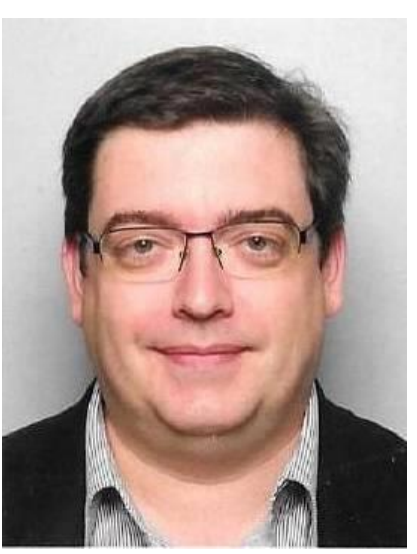
the Coordination division of the French Chemical society in 2015 before being appointed as junior distinguished member of the French Chemical Society in 2016. His research interests are mainly focused on the syntheses and the characterizations of polyoxometalates and their applications in biology or in environmental science. 


\section{Introduction}

Polyoxometalate (POM) compounds, often described as soluble discrete metal-oxide frameworks, constitute a wide family rich of more than several thousand inorganic compounds which can be finely tuned at the molecular level. Owing to their structural and compositional versatility, they display properties and potential applications in numerous fields such as in supramolecular chemistry, ${ }^{[1-4]}$ materials sciences, nanotechnology, ${ }^{[5,6]}$ medicine, ${ }^{[7-9]}$ magnetism, ${ }^{[10-12]}$ catalysis $^{[13-15]}$ or electro-catalysis, ${ }^{[16-18]}$ which explain that the number of publications concerning polyoxometalates exploded over the last two decades. They can be split into two subclasses, namely hetero- and iso-polyanions. The former are obtained through bottom-up self-assembly reactions of $\left[\mathrm{MO}_{\mathrm{x}}\right]$ polyhedra of high-valent early transition metals, mainly $\mathrm{V}(\mathrm{IV}, \mathrm{V}), \mathrm{Mo}(\mathrm{V}, \mathrm{VI})$ or $\mathrm{W}(\mathrm{V}, \mathrm{VI})$, around template anions which can be $\mathrm{PO}_{4}{ }^{3-}, \mathrm{AsO}_{4}{ }^{3-}$, $\mathrm{SiO}_{4}{ }^{4-}, \mathrm{GeO}_{4}{ }^{4-}, \mathrm{AsO}_{3}{ }^{3-}, \mathrm{SbO}_{3}{ }^{3-}$ or $\mathrm{IO}_{6}{ }^{5-}$ for example. Heteropolyanions are subdivided into three main archetypical structures: Anderson-Evans, Keggin or Dawson types depicted in Figure 1. A controlled hydrolysis of the two latter provides a large panel of vacant reactive heteropolyoxometalates, viewed as inorganic ligands, which can coordinate transition metals, coordination complexes or organometallic moieties. The choice of the components is determinant to design the final architectures and their physical properties. ${ }^{[19-25]}$ In particular, the elaboration of hybrid functional POM-based molecules by grafting organic groups or complexes allows tuning their solubility, charge, electronic and electrochemical properties, as well as the capability to self-organize onto various surfaces ${ }^{[26,27]}$ and to interact with biomolecules, membranes or proteins and finally allows combining the properties of the POM with the properties of the appended subunit for the design of multifunctional devices. ${ }^{[24,28,29]}$

In contrast, in absence of heteroatom provided by a template anion, a second class of POMs named isopolyanions is obtained. The Linqvist structure $\left[\mathrm{M}_{6} \mathrm{O}_{19}\right]^{\mathrm{x}-}$ and its derivatives (Figure 1) are probably the main archetypical structure of this class but in the domain of isopolyoxomolybdates, Müller et al. opened a new field of investigation when they reported the discovery of a fullerene-like, all-inorganic hollow spheres containing 132 molybdenum centers in 1998 (Figure 1). ${ }^{[30]}$ These striking nanoscopic ions, called Keplerate-type clusters exhibit an inorganic metal-oxide shell with the general formula $\left[\left(\mathrm{M}_{6}^{\mathrm{VI}} \mathrm{O}_{21}\right)_{12}(\text { linker })_{30}(\text { Ligand })_{30}\right]^{\mathrm{n}-}$ with $\mathrm{M}=\mathrm{Mo}$ or $\mathrm{W}$. The 30 linkers correspond to either monometallic cations such as $\mathrm{Fe}^{3+}, \mathrm{Cr}^{3+}, \mathrm{VO}_{2}^{+}$or to the dimolybdic cationic units $\left\{\mathrm{Mo}_{2} \mathrm{O}_{2} \mathrm{E}_{2}\right\}^{2+}$, with $\mathrm{E}=\mathrm{O}$ or $\mathrm{S}$ and bridge the $12\left\{\mathrm{M}_{6}^{\mathrm{VI}} \mathrm{O}_{21}\right\}$ pentagonal units, while the ligands are usually sulfates or carboxylates. ${ }^{[21,31-33]}$ Not only aesthetic, these nanometric 
hollow clusters behave as functional nanoflasks for cations or molecules trapping, ${ }^{\text {[34-37] }}$ catalysis $^{[38]}$ or specific chemical transformations. ${ }^{[39]}$ This family of polyoxomolybdates was also complemented by other giant POMs namely the "big wheels" $\{$ Mo-154\}, $\{$ Mo-176 $\}$ and $\{$ Mo-248\}, and the "blue lemon" $\{$ Mo-368\}, which expanded the frontiers of inorganic chemistry to the mesoscopic world (see Figure 1). ${ }^{[21,31]}$

Despite the wide variety of compounds, all of them exhibit one common property: they are negatively charged and therefore associate to counter cations to reach electroneutrality! The latter cations are often mistakenly considered as spectator ions but as recently highlighted by Streb and Nyman the nature of the cations is clearly of prime importance for designing their properties and their applications. ${ }^{[40]}$

Owing to the extended scope of properties and potential applications of POMs, various strategies have been investigated to design POM-based functional materials. The encapsulation of POMs within more or less sophisticated organic cations, usually tertraalkylammonium, featuring one or two long hydrocarbon chains, by electrostatic interactions leads to so-called Surfactant Encapsulated Clusters (SEC), which can be used to prepare gels, Langmuir-Blodgett films, ${ }^{[41-43]}$ modified electrodes,${ }^{[44]}$ materials for catalysis, ${ }^{[45]}$ vesicles $^{[46]}$ or precursor for functionalization of mesoporous silica. ${ }^{[47]}$ A recent review of Lixin $\mathrm{Wu}$ gives an overview of such a rich family of compounds at the boundary between molecular chemistry and chemistry of materials relevant to tackle today's challenges. ${ }^{[48]}$

The scope of this review is to demonstrate how the choice of the organic cations in such versatile POM hybrids, can lead to either the formation of ionic liquid crystal phases or true ionic liquids (see Figure 2). These domains are relatively new since the first publications were published in 2004-2005. The first part will focus on POM-based Ionic Liquid Crystals, from their preparation to their characterization and properties. A second part will be devoted to real POM-based ILs. For this part, it is interesting to note that the combination of the two keywords "Polyoxometalate" and "Ionic Liquids" (IL) entered in the web of knowledge gives 550 hits. However, a careful investigation of these papers evidences an abuse of language for number of them. In the past decade, many studies have been reported to utilize cations typically used in Ionic Liquids such as imidazoliums, free or grafted on surfaces, as adjustable counter-cations or anchoring functions to pair with POMs. Such pairing leads usually to solid salts or materials. Even if they are of interest for many applications, they cannot be formally considered as Ionic Liquids and it precludes accurate bibliography on true POM-based ionic 
liquids (POM-ILs). In this review we will thus come back on the definition of what the true Ionic Liquids are and we will try to give a complete overview of true POM-ILs synthetized and characterized in the literature within the last 15 years. A particular attention will be paid to their applications in different fields and especially for catalysis.

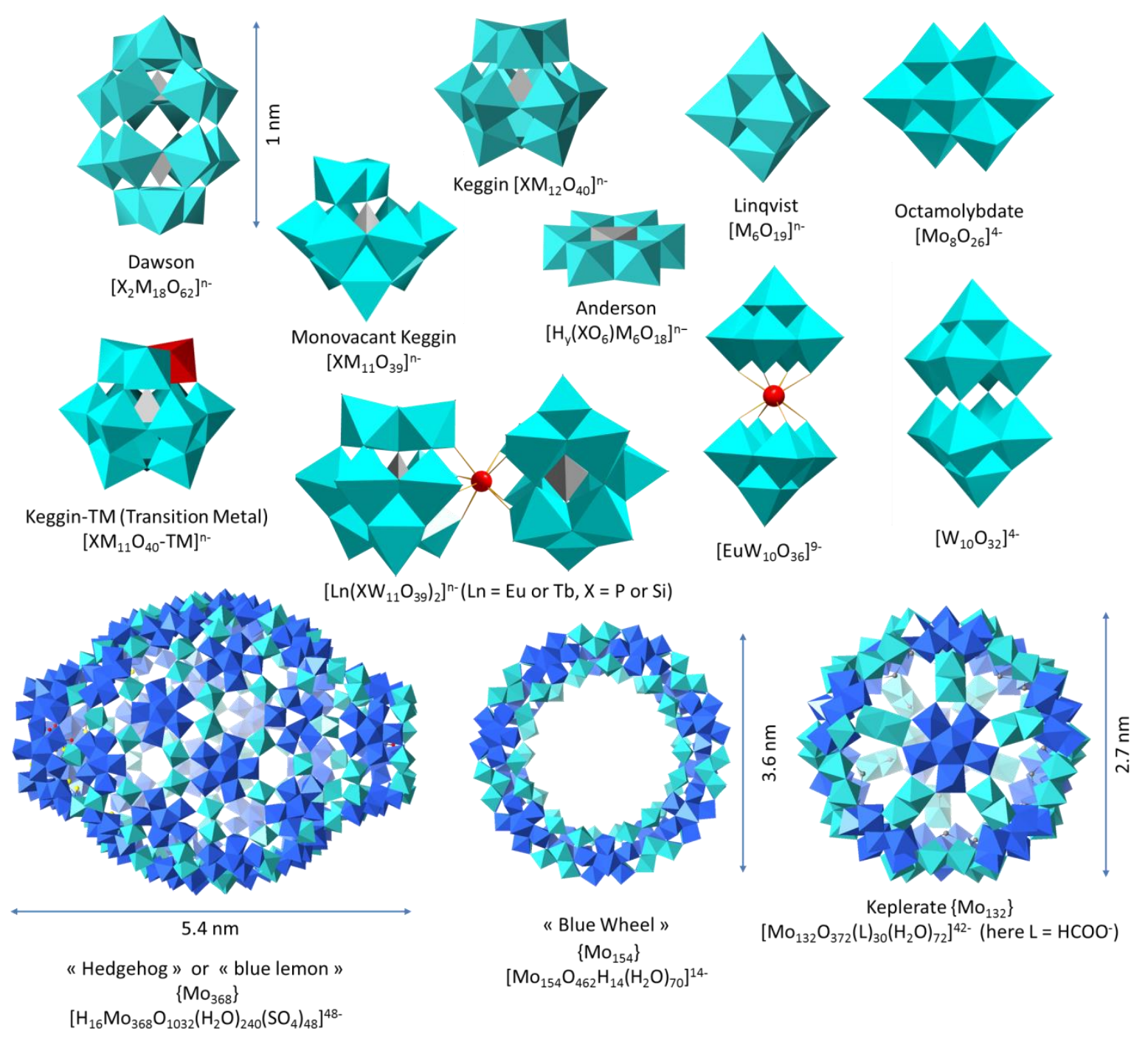

Figure 1. Structures of the archetypical POMs and the most common POMs used in POM-ILs and POMbased Ionic Liquid crystals. 


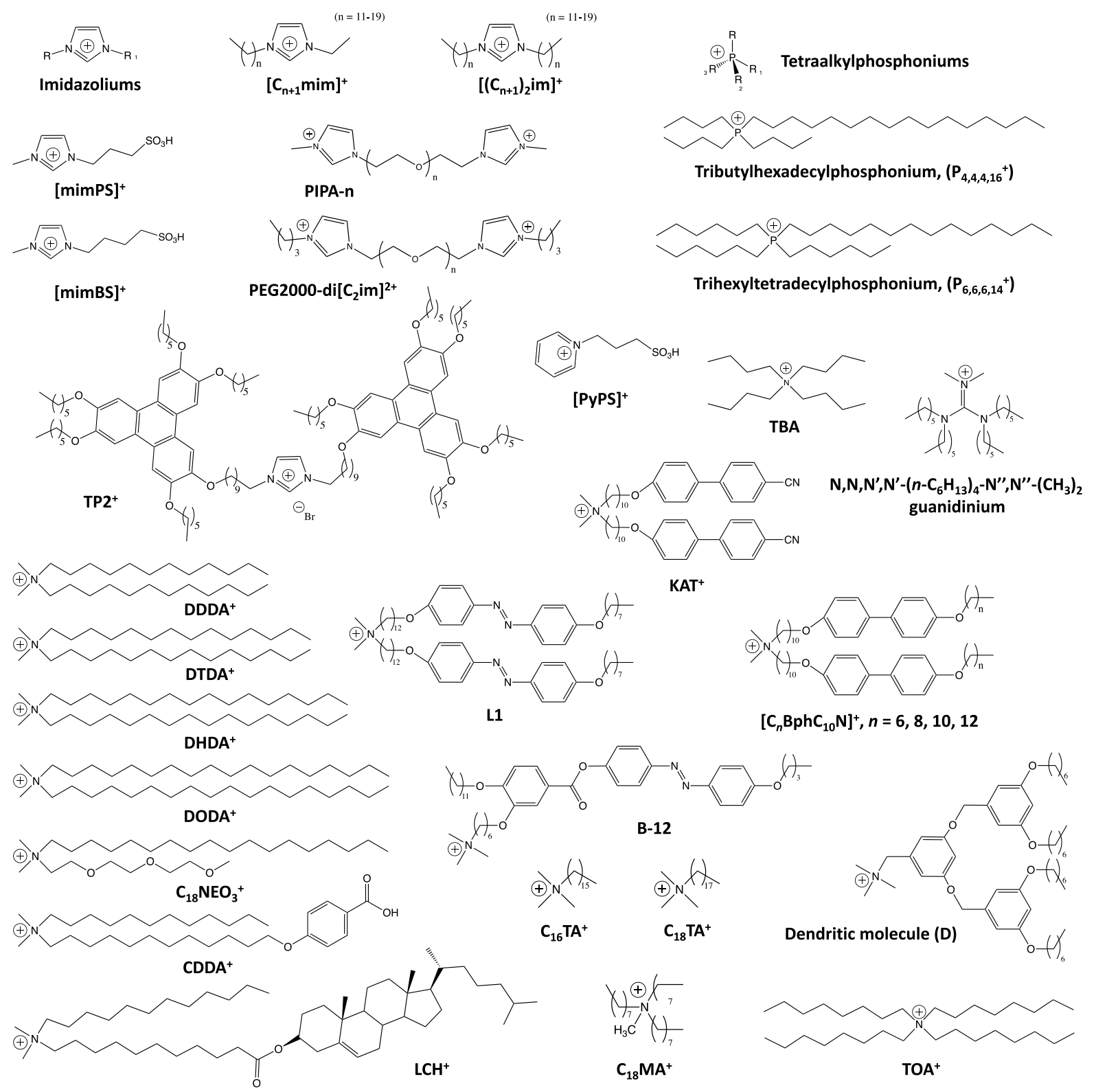

Figure 2: Imidazoliums, phosphoniums and alkylammoniums cations used for designing POM-LIs and POM base ionic liquid crystals. Abbreviations are those used in the literature by their authors.

\section{1- POM-based Ionic liquid crystals}

\section{1-1. Generalities}

Liquid crystals constitute a fascinating example of functional self-assembled materials. Considering the high diversity of POM architectures and their properties, the incorporation of such inorganic components into liquid crystalline phases is particularly relevant for the elaboration of synergistic multifunctional materials. ${ }^{[49,50]}$ Figure 3 summarizes the different 
arrangements which can be found in liquid crystal phases. Note that even if the POMs are almost isotropic in shape, the assembly of cations surrounding the POMs is not randomized. The assembly thus formed exhibits anisotropic shape fully compatible with the schematic views in Figure 3. ${ }^{[51]}$ The Nematic phase $(\mathrm{N})$ corresponds to the least ordered mesophase. It displays only one orientational order corresponding to the main molecular axis. Smectic phases exhibits one additional degree of ordering and are lamellar phase. These phases are easily identified by small angle X-Ray diffraction since the diffraction lines (001) are easily observed and give directly the interlayer distances. However, one can distinguish smectic A, $\mathrm{B}, \mathrm{C}, \mathrm{I}$ or $\mathrm{F}$ types which differ in the orientation of the molecules within the layers as shown in Figure 3 and their identification is more difficult. Finally, the columnar phases results from the stacking of disc-like molecules or dendritic compounds in which molecules interact together into 2D-lattices. Depending on the packing mode, the columnar phases are distributed over hexagonal, rectangular, oblique or square columnar phase. This kind of phase is rarely observed with POMs.

(a)

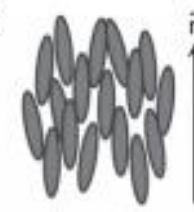

Nematic
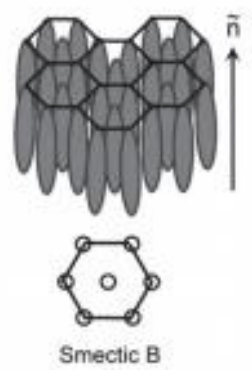

(b)

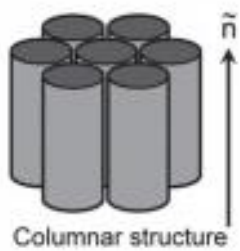

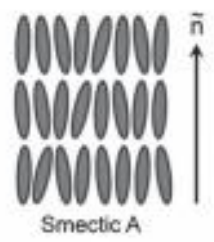
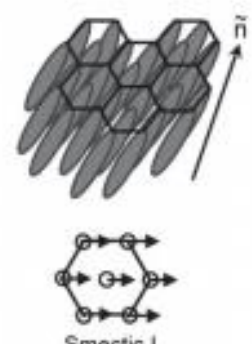

Smectic 1

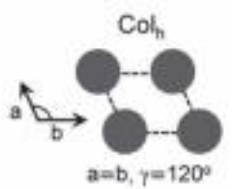

Col,

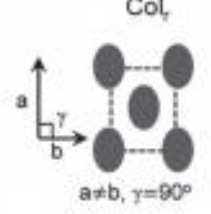

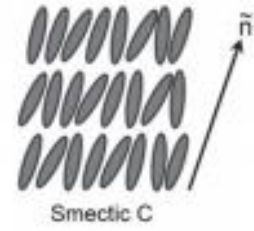
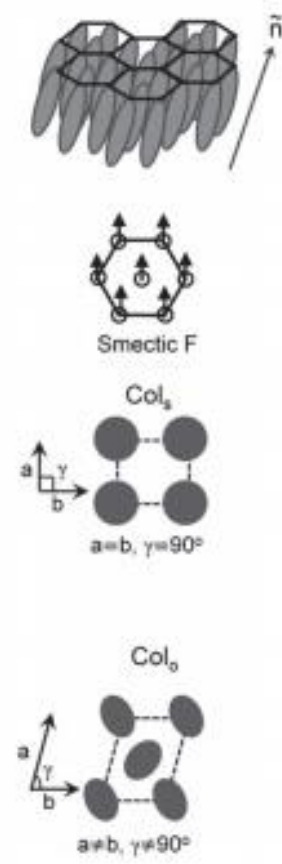

Figure 3. (a) Arrangement of molecules or clusters in nematic or lamellar smectic A, B, C, I or F phases; (b) Schematic representation of Hexagonal $\left(\mathrm{Col}_{\mathrm{h}}\right)$, rectangular $\left(\mathrm{Col}_{\mathrm{r}}\right)$, oblique $\left(\mathrm{Col}_{\mathrm{o}}\right)$ and square columnar phases. (Reprinted from Lixin Wu et al. ${ }^{[51]}$ with the permission from Wiley.) 
A large part of the metallomesogens are prepared by chemical modification of organic ligands coordinated to the metal, which offers a large panel of materials tuned by the design of the organic part. ${ }^{[52-57]}$ Such approach is very rarely used in the POMs chemistry, probably because of the difficulty to work with hybrid POMs, especially in terms of purification. We can cite however, the work of Song, Guo and coworkers, ${ }^{[58]}$ who synthetized dendritic-like hybrid POM with covalently grafted azobenzene mesogenic moieties. This compound is depicted in Figure 4. Although no liquid crystal property was evidenced for this amazing compound, the authors demonstrated that it could participate to the stabilization of liquid crystal phases. In contrast, Polarz et al. ${ }^{[59]}$ synthetized a TBA salt (Figure 2) of the hybrid POM $\left[\mathrm{Ru}^{\text {III }}(\mathrm{L})_{n} \mathrm{PW}_{11} \mathrm{O}_{39}\left(\mathrm{O}\left(\mathrm{SiC}_{16} \mathrm{H}_{33}\right)_{2}\right]^{2-}\right.$ which exhibits a columnar liquid crystal phase in which the columns are constituted by cylindrical aggregates resulting from a micellar selfassembly of the POM. ${ }^{[59]}$ It constitutes, to our knowledge, the only example of hybrid POMbased Liquid Crystal phase of the literature.

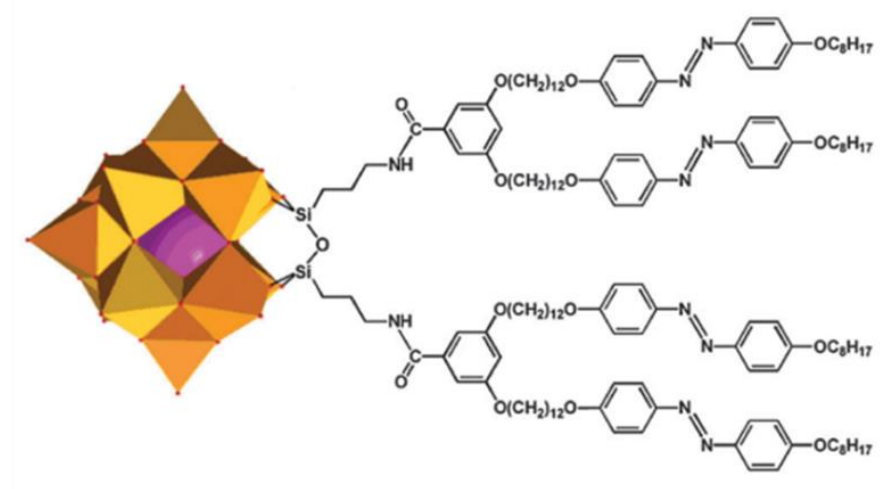

Figure 4: Representation of the dendritic-like hybrid POM synthetized by Song, Guo et al. ${ }^{[58]}$ (Reprinted from Song, Guo et al. ${ }^{[58]}$ with the permission from the Royal Society of Chemistry.)

\section{1-2. Ion Pairing approach}

The other approach consists in pairing inorganic clusters or POMs with organic cations possessing long alkyl chains and bearing mesogenic functions or not. The synthesis of such POM-based materials usually follows similar strategies. The POM as alkali or ammonium salt is solubilized in water and the organic cations solubilized in organic solvent, usually chloroform, dichloromethane or toluene, are introduced in stoichiometric proportions or in excess. The biphasic mixture is vigorously stirred at room temperature or under heating allowing the transfer of the POM into the organic phase. The SEC is then isolated by evaporation of the solvent or by precipitation with ethanol yielding a viscous paste or solid powder. In addition to usual characterizations, the liquid crystal properties of these materials 
are investigated at least by the combination of Polarized Optical Microscopy, Differential Scanning Calorimetry and Small-angle X-Ray Diffraction. NMR and FT-IR spectroscopies can also be helpful to understand the formation of mesophases. NMR in the solid state or in solution allows characterizing the interactions between the cations and the POM, while FT-IR in the solid state allows analysing the organization within the solid when cations bearing alkyl chain are used since the symmetric and antisymmetric stretching vibration bands of the terminal $-\mathrm{CH}_{3}$ and of the $-\mathrm{CH}_{2}$ - groups depend on the symmetry of the molecules and the interaction within the solid. ${ }^{[60]}$

Whatever the chosen approach, several key points must be satisfied to get liquid crystal phases. A minimum ratio between the surface of the organic chains and the surface of the cluster is needed to hopefully get liquid crystals. Secondly, interactions between organic chains around each inorganic cluster or POM must occur. In the field of liquid crystals, this point is usually accomplished by introducing aromatic functions such as cyanobiphenyl groups, called mesogenic functions, on the organic parts which will create $\pi-\pi$ interactions between organic parts and thus favor the organization within the solid. Finally, it is also necessary to take into account the interaction between POM and organic cation. They are often neglected but, even in solution, these interactions can be relatively strong as shown for example by Cadot et al. with Keplerate compounds. ${ }^{[61]}$ Therefore to build LC phase, a compromise between the strength of the interaction and the freedom of the cation around the POM must be found. The different approaches based on ion pairing will be developed in the following sections.

\section{Pairing POMs with cation functionalized with mesogenic functions}

The formation of POM-based liquid crystals by association with mesogenic cations has been developed by the group of Lixin Wu since its first pioneering work published in 2005. From 2005 up to date, $\mathrm{Wu}$ and his collaborators have studied very precisely many parameters which can influence the formation, the nature and the stabilization of POM-based mesophases. In particular, they explored the influence of the size, the shape or the charge of POMs, as well as the influence of the nature of mesogenic cations, their size, their protonation state, their symmetry or the influence of the introduction of functions capable of producing hydrogen bonds or capable of introducing chirality. It is this amazing work translated by number of papers we will try to summarize in this section. In 2005 and 2006, $\mathrm{Wu}$ et al. started to associate an azobenzene containing cationic surfactant called L1 (see 
Figure 2) with the POMs $\left[\mathrm{Tb}\left(\mathrm{SiW}_{11} \mathrm{O}_{39}\right)_{2}\right]^{13-},\left[\mathrm{Eu}\left(\mathrm{PW}_{11} \mathrm{O}_{39}\right)_{2}\right]^{11-}$, and $\left[\mathrm{EuW}_{10} \mathrm{O}_{36}\right]^{9-} \cdot{ }^{[62,63]}$ For the three salts $(\mathrm{L} 1)_{13}\left[\mathrm{~Tb}\left(\mathrm{SiW}_{11} \mathrm{O}_{39}\right)_{2}\right],(\mathrm{L} 1)_{11}\left[\mathrm{Eu}\left(\mathrm{PW}_{11} \mathrm{O}_{39}\right)_{2}\right]$, and $(\mathrm{L} 1)_{9}\left[\mathrm{EuW}_{10} \mathrm{O}_{36}\right]$, different phase transitions were detected by DSC and in each case two different types of smectic liquid crystal phase were identified by X-ray diffraction and polarized optical microscopy. The interlayer distance was found compatible with L1 aligned along the axis of the POM and partial interdigitation of the alkyl chain of L1 was suggested. Interestingly, for the three materials, the phase transitions were found very similar to those of cation L1 alone, which suggested that the thermal behavior of these materials is driven by L1. The three POMs being similar in terms of shape and size, the comparison of these three salts allowed to investigate on the role of the charge of the POM. In this case, it varies from 13- to 9- and the authors observed that it does not influence the phase transitions in the low temperature region but only the clearing point of the materials which decreases from $185{ }^{\circ} \mathrm{C}$ to $164{ }^{\circ} \mathrm{C}$. Careful studies were performed by variable temperature FT-IR measurements and they concluded that the mesophases are stabilized by higher charges and by stronger interactions between cations and POMs. ${ }^{[62]}$ In the following of this work, the same cation L1 was combined with $\left[\mathrm{PW}_{12} \mathrm{O}_{40}\right]^{3-}$ and $\left[\mathrm{SiW}_{12} \mathrm{O}_{40}\right]^{4-}$, as alkali salts or as acids. ${ }^{[64]}$ In the presence of protons, the azobenzene group of L1 can be protonated for giving the dication noted HL1. Interestingly, the anchoring site with POMs remains the ammonium head and the charge of protonated azobenzene groups is balanced by bromide anions. Four new materials $(\mathrm{HL} 1)_{3}\left[\mathrm{PW}_{12} \mathrm{O}_{40}\right] \mathrm{Br}_{3} .2 \mathrm{H}_{2} \mathrm{O}, \quad(\mathrm{L} 1)_{3}\left[\mathrm{PW}_{12} \mathrm{O}_{40}\right] .4 \mathrm{H}_{2} \mathrm{O}, \quad(\mathrm{L} 1)_{2}(\mathrm{HL} 1)_{2}\left[\mathrm{SiW}_{12} \mathrm{O}_{40}\right] \mathrm{Br}_{2} \cdot 2 \mathrm{H}_{2} \mathrm{O}$, $(\mathrm{L} 1)_{4}\left[\mathrm{SiW}_{12} \mathrm{O}_{40}\right] \cdot 2 \mathrm{H}_{2} \mathrm{O}$ were obtained. For $\left[\mathrm{SiW}_{12} \mathrm{O}_{40}\right]^{4-}$ derivatives different types of smectic phases were observed as a function of the protonation state of $\mathrm{L} 1$ : $\mathrm{SmC}$ and $\mathrm{SmA}$ phases for $(\mathrm{L} 1)_{2}(\mathrm{HL} 1)_{2}\left[\mathrm{SiW}_{12} \mathrm{O}_{40}\right] \mathrm{Br}_{2} \cdot 2 \mathrm{H}_{2} \mathrm{O}$ and only $\mathrm{SmB}$ phase for $(\mathrm{L} 1)_{4}\left[\mathrm{SiW}_{12} \mathrm{O}_{40}\right] \cdot 2 \mathrm{H}_{2} \mathrm{O}$. In contrast, similar SmB phases are obtained for the two derivatives of $\left[\mathrm{PW}_{12} \mathrm{O}_{40}\right]^{4-}$, which indicated that the protonation state of L1 does not play a role in the organization of the smectic phase with this POM conversely to the more charged $\left[\mathrm{SiW}_{12} \mathrm{O}_{40}\right]^{4-}$ POM. The authors carefully analysed the effects of the protonation on the properties of the L1 cation in terms of competitive balance between the phase separation and the volume minimization of surfactant which play an important role and suggested to use these properties for developing acidity stimulation response hybrid liquid crystal materials. ${ }^{[64]}$ In 2008 also, they changed the L1 cation by the cation $\mathrm{C}_{\mathrm{n}} \mathrm{BphC}_{10} \mathrm{~N}^{+}$with $\mathrm{n}=6,8,10$ or $12 .{ }^{[65]}$ As seen in Figure 2, the two long organic chains incorporate biphenolic group which are terminated by alkyl chain with variable length. These size-adjustable cations were paired with the four POMs $\left[\mathrm{Eu}\left(\mathrm{BW}_{11} \mathrm{O}_{39}\right)_{2}\right]^{15-}$, $\left[\mathrm{BW}_{12} \mathrm{O}_{40}\right]^{4-},\left[\mathrm{PW}_{12} \mathrm{O}_{40}\right]^{3-}$, and the Anderson derivative $\left[\mathrm{ZnH}_{6} \mathrm{Mo}_{6} \mathrm{O}_{24}\right]^{3-}$. The objectives of 
this study were first to investigate the influence of the tail alkyl chain length. The POM $\left[\mathrm{Eu}\left(\mathrm{BW}_{11} \mathrm{O}_{39}\right)_{2}\right]^{15-}$ was associated to four type of cations $\mathrm{C}_{\mathrm{n}} \mathrm{BphC}_{10} \mathrm{~N}^{+}$with $\mathrm{n}=6,8,10$ or 12 for this purpose. For the four materials, the same mesophase sequence Solid1-Solid2-SmCSmA-Isotropic liquid was observed by DSC. Interestingly, the transition temperatures from solid to liquid crystal phase decreased gradually with the increase of the tail length, while the transition temperature in higher temperature region are similar for the four materials. Accordingly to the previous study done with L1 cation, ${ }^{[62]}$ it means that the low temperature region is associated with the hydrophobic interaction of the cation and that the nature of the POM drives the high temperature transitions. In the same work the effect of the nature of the POM was investigated by associating the four POMs $\left[\mathrm{Eu}\left(\mathrm{BW}_{11} \mathrm{O}_{39}\right)_{2}\right]^{15-},\left[\mathrm{BW}_{12} \mathrm{O}_{40}\right]^{4-}$, $\left[\mathrm{PW}_{12} \mathrm{O}_{40}\right]^{3-}$, and $\left[\mathrm{ZnH}_{6} \mathrm{Mo}_{6} \mathrm{O}_{24}\right]^{3-}$ with the same cation $\mathrm{C}_{8} \mathrm{BphC}_{10} \mathrm{~N}^{+}$. The sequences of transitions clearly differs for the four materials and the authors concluded that ordered smectic B phases can form when the diameter of the POM is comparable to the diameter of amphiphiles and finally that the shape and the surface charge density of the POMs play an important role in the formation of the phase architectures. In a next step of his work, Wu and collaborators provides a new strategy to get liquid phases. They introduced a benzoic acid function at the end of one alkyl chain to give the cation $\mathrm{CDDA}^{+}$represented in Figure 2, which was coupled with POMs possessing intrinsic luminescence properties, i.e. $\left[\mathrm{EuW}_{10} \mathrm{O}_{36}\right]^{9-},\left[\mathrm{Eu}\left(\mathrm{PW}_{11} \mathrm{O}_{39}\right)_{2}\right]^{11-}$ and $\left[\mathrm{Eu}\left(\mathrm{SiW}_{11} \mathrm{O}_{39}\right)_{2}\right]^{13-}{ }^{[66]}$ Despite the alkyl chain are smaller compared to previous cations, the terminal benzoic acid triggered the organization of Smectic A or Smectic C phases through the formation of intermolecular H-bonding contacts. The clearing points gradually diminished by passing from $(\mathrm{CDDA})_{9}\left[\mathrm{EuW}_{10} \mathrm{O}_{36}\right]$ to $(\mathrm{CDDA})_{13}\left[\mathrm{Eu}\left(\mathrm{SiW}_{11} \mathrm{O}_{39}\right)_{2}\right]$ and the two materials $(\mathrm{CDDA})_{13}\left[\mathrm{Eu}\left(\mathrm{SiW}_{11} \mathrm{O}_{39}\right)_{2}\right]$ and $(\mathrm{CDDA})_{11}\left[\mathrm{Eu}\left(\mathrm{PW}_{11} \mathrm{O}_{39}\right)_{2}\right]$ exhibited a sequence Solid-SmA-Iso, while $(\mathrm{CDDA})_{9}\left[\mathrm{EuW}{ }_{10} \mathrm{O}_{36}\right]$ gave a sequence involing a SmC phase : Solid-SmC-SmA-Iso. Luminescence properties were observed in the solid state and in the liquid crystal phase and the authors evidenced the dependence of this property as a function of the states of samples, notably with higher quantum yields in the liquid crystal phases. This system was complicated by the introduction of additional pyridine derivatives bearing for the main part of them long alkyl chains, to the materials $(\mathrm{CDDA})_{3}\left[\mathrm{PW}_{12} \mathrm{O}_{40}\right]$ and $(\mathrm{CDDA})_{4}\left[\mathrm{SiW}_{12} \mathrm{O}_{40}\right]{ }^{[67]}$ By formation of $\mathrm{H}$-bonds with the terminal benzoic acid function of $\mathrm{CDDA}^{+}$, the resulting multi-components reverse micelles provided new self-assemblies exhibiting supramolecular liquid crystal properties (SmA, SmB or $\mathrm{SmC}$ ) and the authors studied the effects of the length and the number of alkyl chain on pyridine derivatives as well as the influence of the charge of the POM for the formation of 
adjustable liquid crystal phases. In 2013, Wu et al. kept us this work by grafting T-shape quaternary ammonium cation (see B-12 on Figure 2) onto the surface of the three POMs $\left[\mathrm{BW}_{12} \mathrm{O}_{40}\right]^{5-},\left[\mathrm{SiW}_{11} \mathrm{O}_{39} \mathrm{Co}\left(\mathrm{H}_{2} \mathrm{O}\right)\right]^{6-}$ and $\left[\mathrm{Mn}_{4}\left(\mathrm{H}_{2} \mathrm{O}\right)_{2}\left(\mathrm{VW}_{9} \mathrm{O}_{34}\right)_{2}\right]^{10-} \cdot{ }^{[68]}$ The cation alone was found to exhibit smectic liquid crystal phase. In contrast, due its T-shape, the B-12 cation adopt a lateral attachment with the three POMs and the resulting anisotropic surfactant encapsulated POMs formed nematic phases in the three cases (see Figure5). As seen in this section, lamellar phases are usually observed with POMs and it is the first example of a different design of the cations induces the formation of such a nematic phase. Of course, the effect of the nature of the POM was studied. The three systems gave the same sequences solid-Nematic-Iso and the temperature of the phase transition Solid to Nematic appeared almost identical $\left(29-30{ }^{\circ} \mathrm{C}\right)$ according to a process driven by the cation, while the Nematic to Isotropic Liquid transition increases from $129{ }^{\circ} \mathrm{C}$ for $(\mathrm{B}-12)_{5}\left[\mathrm{BW}_{12} \mathrm{O}_{40}\right]$ to $168{ }^{\circ} \mathrm{C}$ for $(\mathrm{B}-$ 12) $)_{10}\left[\mathrm{Mn}_{4}\left(\mathrm{H}_{2} \mathrm{O}\right)_{2}\left(\mathrm{VW}_{9} \mathrm{O}_{34}\right)_{2}\right]$, once again in agreement with a POM-dependant process.
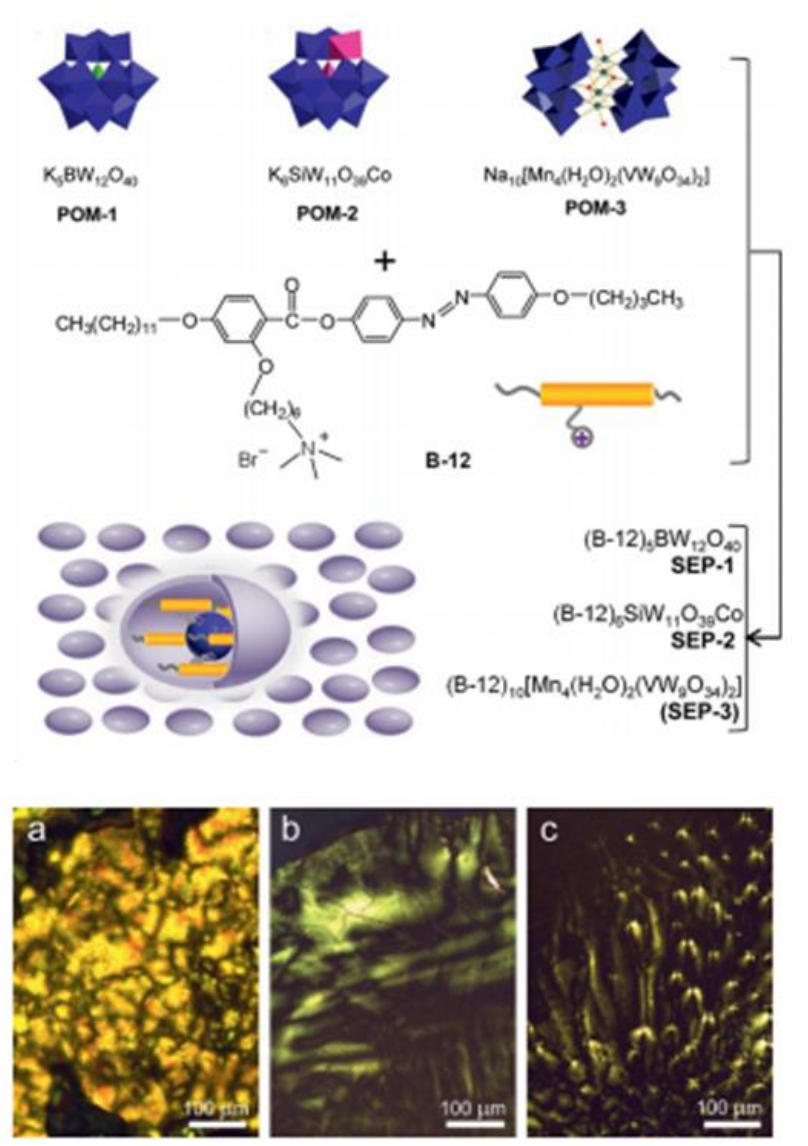

Figure 5. Top: Structural representation of POM-1, POM-2 and POM-3 combined by Wu and coworkers with the cation called $\mathrm{B}-12$ and a proposition of the organization of the resulting nematic phases; Bottom: Polarizing optical images of the resulting SEP-1 at $130{ }^{\circ} \mathrm{C}\left(\right.$ a), SEP-2 at $127^{\circ} \mathrm{C}$ (b) and SEP-3 at $100{ }^{\circ} \mathrm{C}$ (c). (Reprinted from Wu et al. ${ }^{[68]}$ with the permission from Wiley.) 
Finally, two recent papers published in 2017 and 2018 reported the use of a cholesterolcontaining ammonium surfactant called $\mathrm{LCh}^{+}$in Figure 2 which was used for encapsulation of the monovacant POM $\left[\mathrm{PW}_{11} \mathrm{O}_{39}\right]^{7-},{ }^{[69]}$ or the Eu-containing POM $\left[\mathrm{Eu}\left(\mathrm{SiW}_{11} \mathrm{O}_{39}\right)_{2}\right]^{13-} \cdot{ }^{[70]} \mathrm{In}$ addition to be chiral, cholesterols are known to be mesogenic and thus to trigger the formation of mesophases. Liquid crystalline phases were indeed identified for both materials in a wide range of temperature: SmA for the former, less-ordered layer for the latter. For each material, the authors demonstrated by circular dichroism spectroscopy that the chirality of the cholesteric group is transferred to the POM through electrostatic interactions. Furthermore, the material $(\mathrm{LCh})_{13}\left[\mathrm{Eu}\left(\mathrm{SiW}_{11} \mathrm{O}_{39}\right)_{2}\right]$ displayed intrinsic luminescence that could be adjusted with the temperature, thus opening the route towards multifunctional POM-based liquid crystals combining liquid crystal property, luminescence, chirality and chiroptical switches.

In the domain of POMs, probably due to the hard task that constitutes the multi-step synthesis of such sophisticated cations, we did not identify other authors to fill this section. Nevertheless, in the chemistry of metallic clusters, which can be compared to POM in terms of size and charges, Molard et al. probably being inspired by the work of Lixin Wu successfully combined the cluster $\left[\operatorname{Re}_{6} \mathrm{Se}_{8}(\mathrm{CN})_{6}\right]^{\mathrm{n}-}(\mathrm{n}=3,4)$ with the tetraalkylammonium cations functionalized with cyanobiphenyl groups (see cation $\mathrm{KAT}^{+}$in Figure 2) to design “clustomesogens" possessing switchable magnetic/luminescence properties. ${ }^{[71]} \mathrm{F}$. Camerel, Y. Molard and coworkers kept up this work by preparing bulky triphenylene-substituted imidazolium salts (see cation $\mathrm{TP}_{2}^{+}$on Figure 2), which led to a columnar phase when associated with the cluster $\left[\operatorname{Re}_{6} \mathrm{Se}_{8}(\mathrm{CN})_{6}\right]^{4-} \cdot{ }^{[72]}$ These cations, to our knowledge, have never been used with POMs and, taken into account their diversities, it could be interesting to extend this work with POMs.

\section{Pairing POMs with non-mesogenic cations}

Even if the organization of mesophases is favored with mesogenic cations, liquid crystals phases can also be obtained with non-mesogenic cations. It can be due to versatility and the mobility of the cations at the surface of the POMs which renders them capable of deformation into an anisotropic form, but also to the propensity of POMs and organic cations to segregate into their own distinct subphase. ${ }^{[51]}$ The first examples of mesophases obtained by associating non mesogenic cations with a POM was reported by Kurth, Faul et al. in 2009. ${ }^{[73]}$ They synthesized hybrid materials by ionic association of the Preyssler type 
derivative $\left[\mathrm{EuP}_{5} \mathrm{~W}_{30} \mathrm{O}_{110}\right]^{12-}$ (Figure 6) associated with single tail cations hexadecyltrimethylammonium $\left(\mathrm{C}_{16} \mathrm{TA}^{+}\right)$and octadecyltrimethylammonium $\left(\mathrm{C}_{18} \mathrm{TA}^{+}\right)$, double tails cations dimethyldidodecylammonium $\left(\mathrm{DDDA}^{+}\right)$, dimethylditetradecylammonium $\left(\mathrm{DTDA}^{+}\right)$, dimethyldihexadecylammonium $\left(\mathrm{DHDA}^{+}\right)$and dimethyldioctadecylammonium $\left(\mathrm{DODA}^{+}\right)$and triple tail cation trioctadecylmethylammonium $\left(\mathrm{C}_{18} \mathrm{MA}^{+}\right)$. In each case, DSC, SAXS and Polarized Optical Microscopy demonstrated the formation of lamellar liquid crystal phases. The transition temperature from solid to LC phase are found in the $-60.6{ }^{\circ} \mathrm{C}$ to $+77{ }^{\circ} \mathrm{C}$ range depending on the alkyl chain length. Higher transition temperatures are obtained with longer alkyl chains, while the interlayer distances vary concomitantly with the increase of the cations size allowing to propose the lamellar organization depicted in Figure 6.
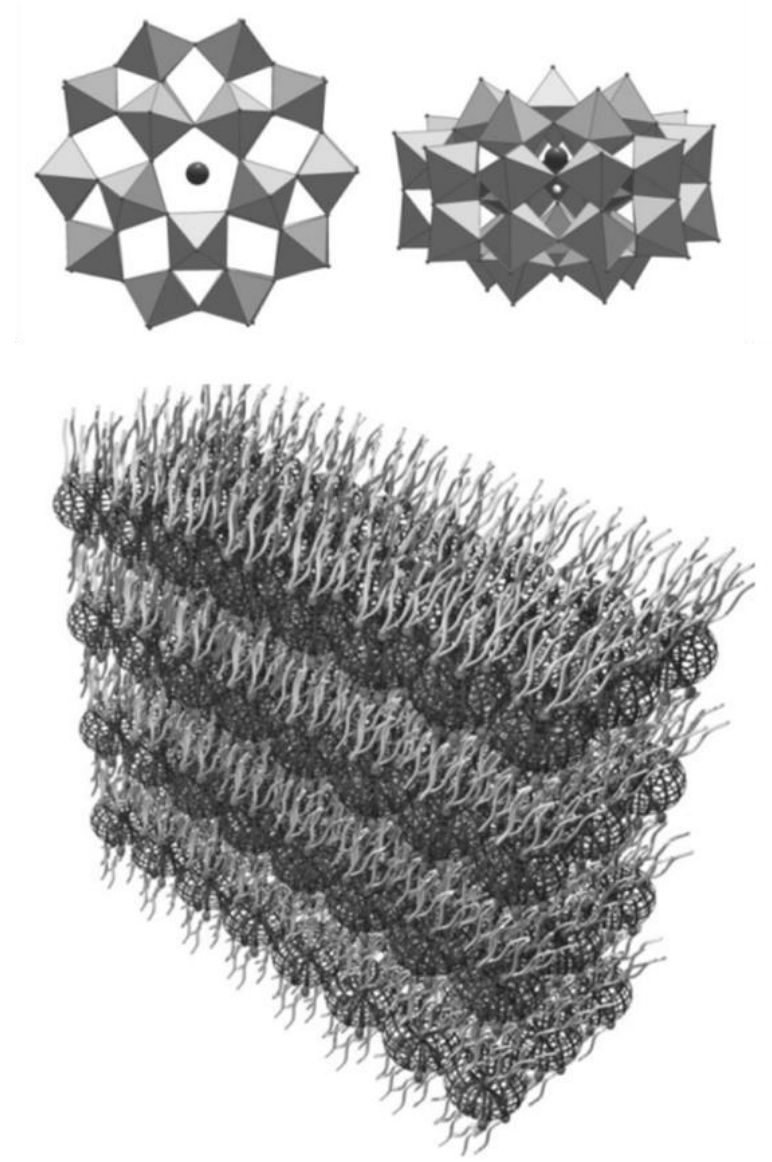

Figure 6. Top and side views of the Preyssler type anion $\left[\mathrm{EuP}_{5} \mathrm{~W}_{30} \mathrm{O}_{110}\right]^{12-}$ and lamellar organization supposed in the liquid crystal phase from the experimental data. (Reprinted from Kurth, Faul et al. ${ }^{[73]}$ with the permission from Wiley.)

In the same year, $\mathrm{Wu}$ and coworkers used an ammonium cation bearing one $\mathrm{C}_{18}$ alkyl chain and one triethylene oxide (TEO) chain ( 
Kegging-type anions $\left[\mathrm{PMo}_{12} \mathrm{O}_{40}\right]^{3-},\left[\mathrm{PW}_{12} \mathrm{O}_{40}\right]^{3-},\left[\mathrm{SiW}_{12} \mathrm{O}_{40}\right]^{4-}$, and $\left[\mathrm{BW}_{12} \mathrm{O}_{40}\right]^{5-} \cdot{ }^{[74]}$ This series notably allowed studying the influence of the charge of the POM since they all have the same shape and size. Besides, although TEO chain is non mesogenic, it can provoke the collapse of the hydrophilic domains upon heating, contribute to the packing and conformation of the alkyl chains and also contribute to decrease the transition temperature from solid to liquid crystal phase. Interestingly, only the $\mathrm{C}_{18} \mathrm{NEO}_{3}^{+}$salts of $\left[\mathrm{PW}_{12} \mathrm{O}_{40}\right]^{3-}$ and $\left[\mathrm{BW}_{12} \mathrm{O}_{40}\right]^{5-}$ displayed a phase transition towards a smectic B liquid crystal phase at $181.4^{\circ} \mathrm{C}$ and 163.9 ${ }^{\circ} \mathrm{C}$, respectively, while the two others decomposed before melting. The authors highlighted the influence of several parameters explaining these results. In particular the crowding around the POM and the strength of interactions between the POM and the cation are of importance. The former notably influences the nature of the phase. For the latter strong POM/cation interactions reduce free motions and thus delay the organization of the cations around the POM in the Liquid Cristal (LC) phase. For instance, the electrostatic forces are stronger between $\left[\mathrm{PMo}_{12} \mathrm{O}_{40}\right]^{3-}$ and cations than with the analogous tungstic POM $\left[\mathrm{PW}_{12} \mathrm{O}_{40}\right]^{3-}$ and finally the transition of the $\left[\mathrm{PMo}_{12} \mathrm{O}_{40}\right]^{3-}$ salt is so delayed that it decomposes before melting. In the following of this work, $\mathrm{Wu}$ and coworkers studied the properties of the materials pairing tetraoctylammonium cation with $\left[\mathrm{PW}_{12} \mathrm{O}_{40}\right]^{3-},\left[\mathrm{GeW}_{12} \mathrm{O}_{40}\right]^{4-}$, or $\left[\mathrm{BW}_{12} \mathrm{O}_{40}\right]^{5-} \cdot{ }^{[75]}$ While $(\mathrm{TOA})_{3}\left[\mathrm{PW}_{12} \mathrm{O}_{40}\right]$ did not exhibit thermotropic LC behavior, (TOA) $)_{4}\left[\mathrm{GeW}_{12} \mathrm{O}_{40}\right]$ and $(\mathrm{TOA})_{5}\left[\mathrm{BW}_{12} \mathrm{O}_{40}\right]$ displayed smectic LC phase above $80.2^{\circ} \mathrm{C}$ and $115^{\circ} \mathrm{C}$, respectively (see Figure 7). This result is interesting since it associates a $\mathrm{TOA}^{+}$cation with four flexible groups and thus a high degree of freedom with a polarizable rigid POM and the two materials $(\mathrm{TOA})_{4}\left[\mathrm{GeW}_{12} \mathrm{O}_{40}\right]$ and $(\mathrm{TOA})_{5}\left[\mathrm{BW}_{12} \mathrm{O}_{40}\right]$ can be thus regarded, from the authors, as ordered ILs. Wu coworkers kept up this work by preparing a series of tetraalkylammonium salts of $\left[\mathrm{SiW}_{12} \mathrm{O}_{40}\right]^{4-}$, alkyl chain being butyl $\left(\mathrm{TBA}^{+}\right)$, hexyl $\left(\mathrm{THA}^{+}\right)$, octyl $\left(\mathrm{TOA}^{+}\right)$or decyl $\left(\mathrm{TDA}^{+}\right) .{ }^{[60]}$ With the two longer alkyl chain, lamellar LC phase were obtained with transition temperatures found at $89.8{ }^{\circ} \mathrm{C}$ and $28.2{ }^{\circ} \mathrm{C}$ for $\mathrm{TOA}^{+}$and $\mathrm{TDA}^{+}$salts respectively. In contrast the salts obtained with the two shorter alkyl chains displayed cubic crystallographic arrangements in the solid state, which demonstrate that playing on the nature of counter cation can modulate the phase from cubic to lamellar liquid crystal phase. These two publications constitute to date, the only examples of POM-based liquid crystal phases obtained with tetraalkylammonium cations usually used in ILs systems and demonstrate that the border between these two domains is not so significant. 

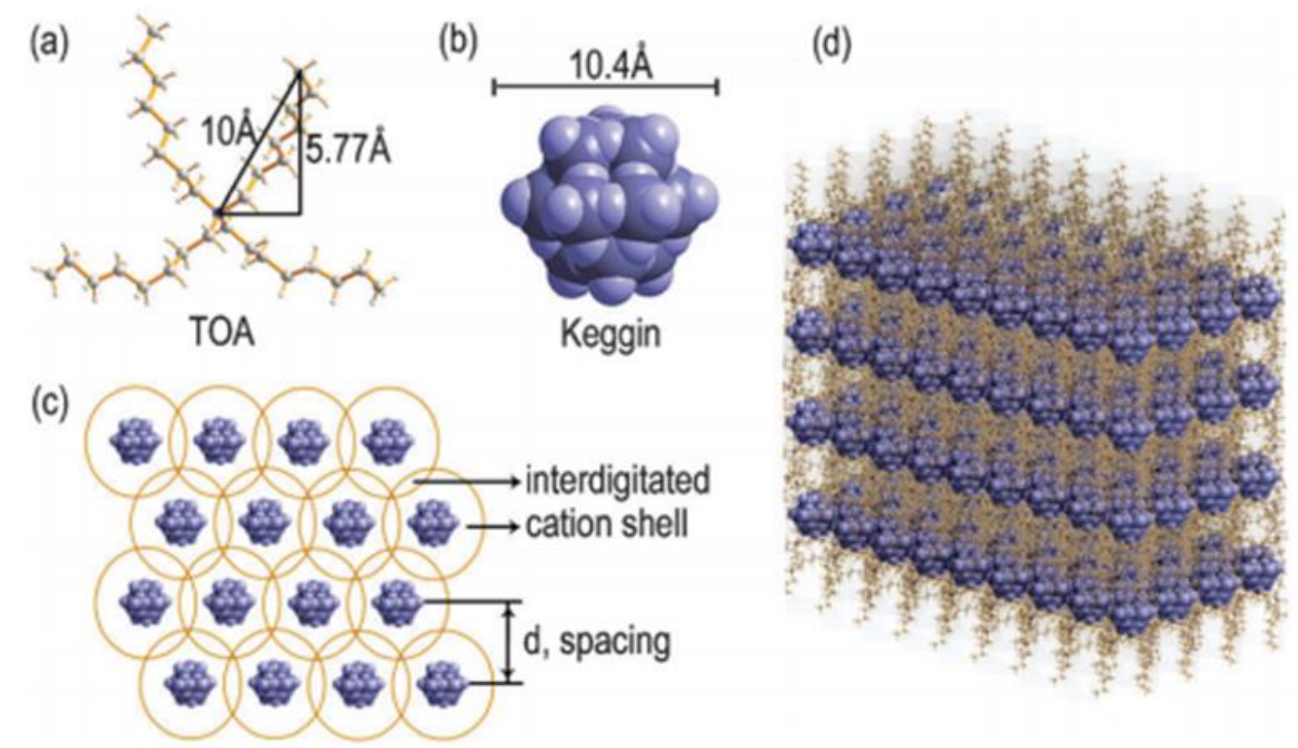

(c)
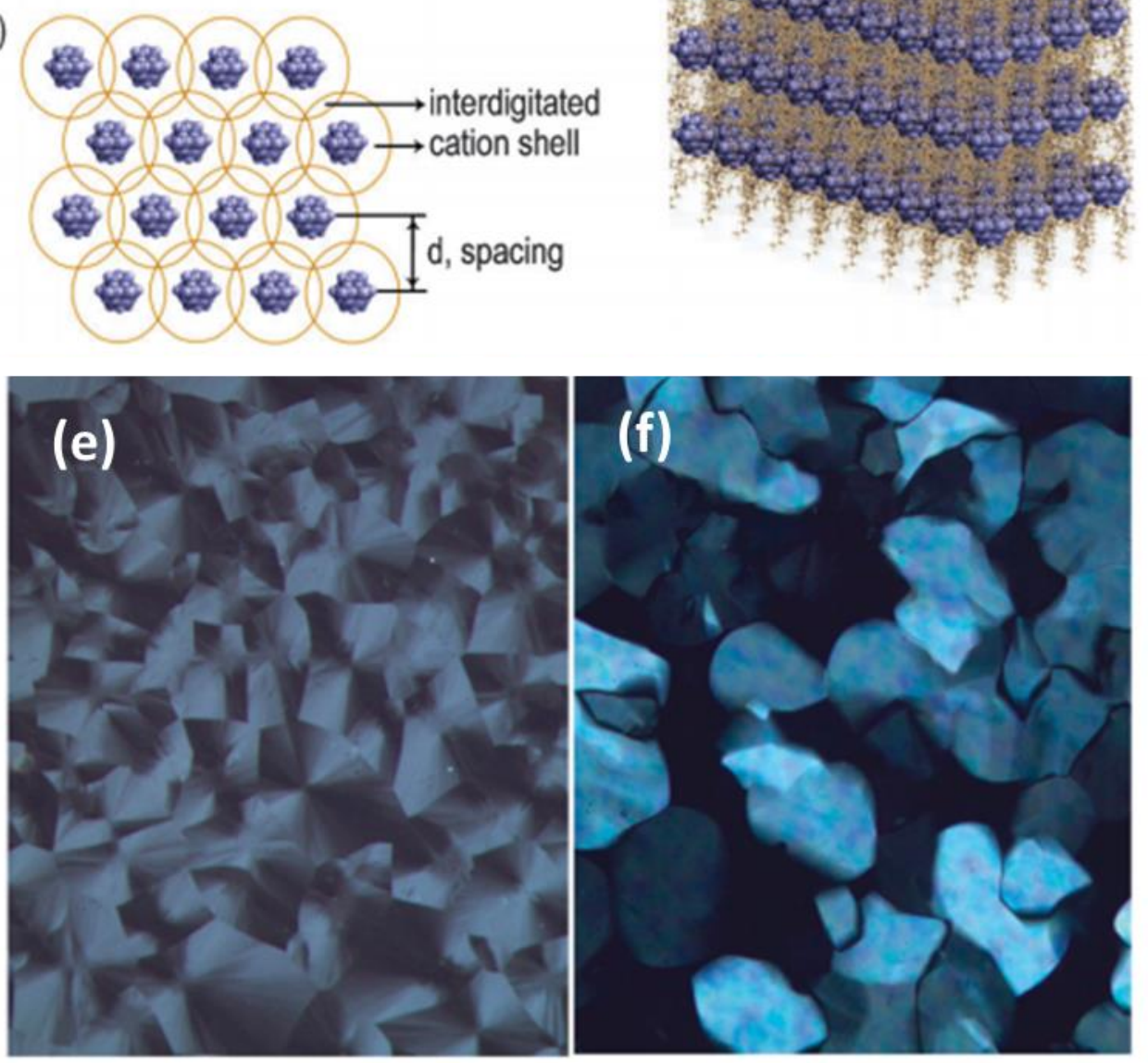

Figure 7. (a) The tetrahedral conformation of $\mathrm{TOA}^{+}$cation; (b) Keggin polyoxoanion in the space-filling mode; (c) representation of arrangement of molecules with partial interdigitation of $\mathrm{TOA}^{+}$alkyl in the LCs state; (d) a proposed lamellar structure of the complexes in the LCs state. (e) Optical textures of complexes obtained under an optical polarized microscope. (TOA) ${ }_{4}\left[\mathrm{GeW}_{12} \mathrm{O}_{40}\right]$ at $85{ }^{\circ} \mathrm{C}$ on heating, and (f) for (TOA) ${ }_{5}\left[\mathrm{BW}_{12} \mathrm{O}_{40}\right]$ at $45^{\circ} \mathrm{C}$ on cooling from isotropic liquid (100x). (Reprinted from Wu et al. ${ }^{[60,75]}$ with the permission from the Royal Society of Chemistry.)

The group of En-Bo Wang also contributed to this field. They focused their attention on the DODA $^{+}$cation which was associated either to the rare Waugh-type and Silverston-type POMs, i.e. $\left[\mathrm{MnMo}_{9} \mathrm{O}_{32}\right]^{6-}$ and $\left[\mathrm{CeMo}_{12} \mathrm{O}_{42}\right]^{8-}$, ${ }^{[76]}$ to the hexavacant Germanomolybdate

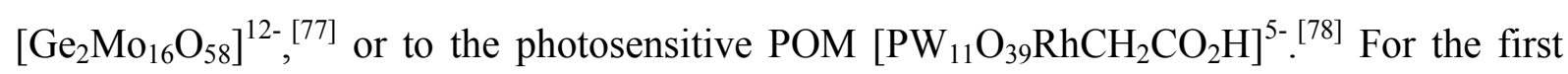
example, the two POMs $\left[\mathrm{MnMo}_{9} \mathrm{O}_{32}\right]^{6-}$ and $\left[\mathrm{CeMo}_{12} \mathrm{O}_{42}\right]^{8-}$ enwrapped within the $\mathrm{DODA}^{+}$ cations gave smectic phases with transition temperatures around $50{ }^{\circ} \mathrm{C}$ and similar interlayer 
spacing despite the difference of charges. The germanomolybdate compound exhibited 4 transitions from solid state to 3 different smectic phases at 61,75 and $82{ }^{\circ} \mathrm{C}$ and finally to isotropic liquid at $116{ }^{\circ} \mathrm{C}$. The nature of the smectic phases were not determined precisely but they observed a decrease of interlayer distance with temperature increase, in agreement with the variation of angle of the cluster formed between DODA cation and the POM with the layer (see Figure 3). For the latter material (DODA) $5\left[\mathrm{PW}_{11} \mathrm{O}_{39} \mathrm{RhCH}_{2} \mathrm{CO}_{2} \mathrm{H}\right]$, a phase transition towards a smectic A liquid crystal phase was observed at $36{ }^{\circ} \mathrm{C}$ and optical studies were performed on this material. Note that in the same study, the tetraheptylammonium salt of $\left[\mathrm{PW}_{11} \mathrm{O}_{39} \mathrm{RhCH}_{2} \mathrm{CO}_{2} \mathrm{H}\right]^{5-}$ was studied and revealed only a melting point at $73{ }^{\circ} \mathrm{C}$, characteristic of a true POM-IL. Finally, one can cite also the recent work of Tan, who paired imidazolium cations, i.e. either 1,3-dioctadecylimidazolium $\left(\mathrm{L}^{+}\right)$or 1-methyl-3-[3,4,5tris(octadecyloxy) benzyl]imidazolium $\left(\mathrm{L}^{,+}\right)$with $\left[\mathrm{SiW}_{12} \mathrm{O}_{40}\right]^{4-}, \quad\left[\mathrm{Eu}\left(\mathrm{SiW}_{11} \mathrm{O}_{39}\right)\left(\mathrm{H}_{2} \mathrm{O}\right)_{2}\right]^{5-}$, $\left[\mathrm{Eu}\left(\mathrm{SiW}_{11} \mathrm{O}_{39}\right)_{2}\right]^{13-},\left[\mathrm{EuW}_{10} \mathrm{O}_{36}\right]^{9-}$, and Keplerate $\left[\mathrm{Mo}_{132} \mathrm{O}_{372}\left(\mathrm{CH}_{3} \mathrm{COO}\right)_{30}\left(\mathrm{H}_{2} \mathrm{O}\right)_{72}\right]^{42-}$ with the aim to study the self-assembly behaviors and aggregates morphology of these hybrids in mixed solution of chloroform-methanol. ${ }^{[79,80]}$ The study of these hybrids revealed the formation of a lamellar phase in the solid state for all these hybrids and a smectic liquid crystal phase was characterized for $\mathrm{L}_{4}\left[\mathrm{SiW}_{12} \mathrm{O}_{40}\right]{ }^{[80]}$

In the work we developed in Versailles, we chose to use dimethyldioctadecylammonium cations $\left(\mathrm{DODA}^{+}\right)$and one step-made alkyl-methylimidazolium $\left[\mathrm{C}_{\mathrm{n}} \mathrm{mim}\right]^{+}$cations substituted with simple alkyl chains ranging from $\mathrm{C}_{12}$ to $\mathrm{C}_{20}$, a strategy which offers the possibility to prepare the subsequent POM-based materials on a large scale. To balance the lack of mesogenic function on the cations, we first selected keplerate-type POMs $\left[\mathrm{Mo}_{132} \mathrm{O}_{372}\left(\mathrm{CH}_{3} \mathrm{COO}\right)_{30}\left(\mathrm{H}_{2} \mathrm{O}\right)_{72}\right]^{42-}$ and $\left[\mathrm{Mo}_{132} \mathrm{~S}_{60} \mathrm{O}_{312}\left(\mathrm{SO}_{4}\right)_{n}\left(\mathrm{H}_{2} \mathrm{O}\right)_{132-2 \mathrm{n}}\right]^{(12+2 \mathrm{n})-}(\mathrm{n}=23$ or 30) mainly because of their high charges in aim to force the occurrence of Van der Waals interactions between the large number of counter cations. The synthetic procedure was similar to that of Lixin $\mathrm{Wu}$ excepted that a very large excess of organic cations in chloroform was used to fully extract the POMs from the aqueous phase and that the target materials were precipitated from chloroform phase by addition of ethanol. Using this strategy, a series of eight new materials based on the ionic association between 1-methyl-3-alkylimidazolium cations and $\left[\mathrm{Mo}_{132} \mathrm{O}_{372}\left(\mathrm{CH}_{3} \mathrm{COO}\right)_{30}\left(\mathrm{H}_{2} \mathrm{O}\right)_{72}\right]^{42-}$ has been obtained. ${ }^{[81]}$ For the major part of them a self-organization in lamellar mesophases was evidenced. From the structural parameters $h$ and the intercluster distance $a_{\mathrm{hex}}$, we demonstrated that the cations are not randomly organized around the anionic cluster and that the alkyl chains of the cations are 
certainly folded, which limits the van der Waals interaction between the cations within the liquid crystal phase and therefore is detrimental to the quality of the mesophases. Replacing 1-methyl-3-alkylimidazolium cation by $\mathrm{DODA}^{+}$cation bearing two $\mathrm{C}_{18}$ alkyl chain per cation, allowed favoring Van der Waals interactions between alkyl chains of cations. In this case temperature dependent Polarized Optical Microscopy revealed the formation of a birefringent fluid and homogeneous texture characteristic of the liquid-crystalline nature of the sample (see Figure 8). ${ }^{[82]} \mathrm{We}$ demonstrated that the ionic salt $(\text { DODA })_{36}\left(\mathrm{NH}_{4}\right)_{6}\left[\mathrm{Mo}_{132} \mathrm{O}_{372}\left(\mathrm{CH}_{3} \mathrm{COO}\right)_{30}\left(\mathrm{H}_{2} \mathrm{O}\right)_{72}\right] \cdot 75 \mathrm{H}_{2} \mathrm{O}$ self-organizes into a layered liquidcrystalline phase between $9^{\circ} \mathrm{C}$ and decomposition temperature $\left(220^{\circ} \mathrm{C}\right)$ after removing of water. We also proposed a simple model of organization of the mesophase, including Keplerate-type clusters with surrounding $\mathrm{DODA}^{+}$within the layers of the mesophase. The interlayer distance is found to be $27 \AA$, lower than the diameter of the keplerate capsule (30 $\AA$ ), which suggests a shift and thus the interpenetration of the layers with each other as depicted in Figure 7. Interestingly, the overall structure as well as the stoichiometry of this salt are very close to that previously synthesized by Volkmer et al. ${ }^{[41,42]}$ and by Barboiu et $a l^{[47]}$ For the former, they used this compound to prepare hexagonal organized layers on surfaces while the later used it for immobilization within silica matrix but none of them reported such liquid crystal property. Another example of very similar compound obtained with smaller didodecyldimethylammonium $\left(\mathrm{DDDA}^{+}\right.$)-encapsulated $\mathrm{Mo}_{132}$ was reported by Volatron and Proust. ${ }^{[83]}$ In this case, the alkyl chain length is probably too small to get liquid crystals phase but they used it to prepare coassembly of spherical $6.2 \mathrm{~nm}$ maghemite $(\gamma$ $\mathrm{Fe}_{2} \mathrm{O}_{3}$ ) nanocrystals and $\{$ Mo- 132$\}$ surrounded by DDDA ${ }^{+}$cations. Finally, in a last part of this work, we change the "classical" \{Mo-132\} keplerate compound $\left[\mathrm{Mo}_{132} \mathrm{O}_{372}\left(\mathrm{CH}_{3} \mathrm{COO}\right)_{30}\left(\mathrm{H}_{2} \mathrm{O}\right)_{72}\right]^{42-}$ by the sulfurated one $\left[\mathrm{Mo}_{132} \mathrm{O}_{312} \mathrm{~S}_{60}\left(\mathrm{SO}_{4}\right)_{30}\left(\mathrm{H}_{2} \mathrm{O}\right)_{72}\right]^{72-}(x$ ranging from 15 to 30 ) including sulphate ions instead of acetate ions, sulfides instead of oxo ligands and higher charge. ${ }^{[33]}$ The larger charge of the capsule allows associating more $\mathrm{DODA}^{+}$cations interacting with these nanoscopic systems. Interestingly, the lamellar organization with $\mathrm{DODA}^{+}$cations within the sheets is maintained with an increasing value of interlayer distance for $(\mathrm{DODA})_{56}\left(\mathrm{NH}_{4}\right)_{16}\left[\mathrm{Mo}_{132} \mathrm{~S}_{60} \mathrm{O}_{312}\left(\mathrm{SO}_{4}\right)_{30}\left(\mathrm{H}_{2} \mathrm{O}\right)_{72}\right] \cdot 15 \mathrm{H}_{2} \mathrm{O}$ up to $34 \AA .^{[84]}$ 


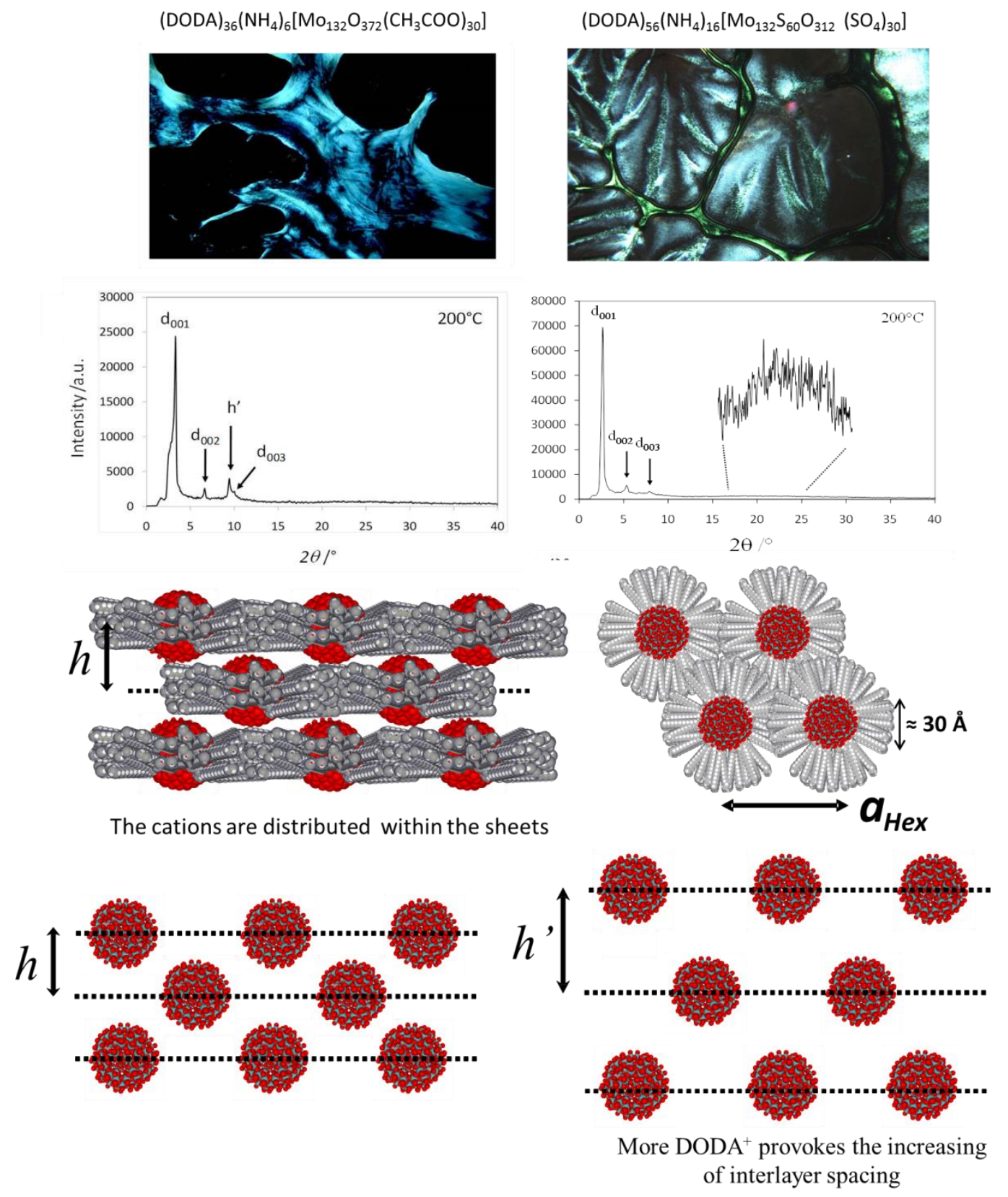

Figure 8. Top: Comparison of Fluid and Birefringent Optical textures of the SmA mesophase and of the Small angle $\mathrm{X}$-ray patterns of $(\mathrm{DODA})_{36}\left(\mathrm{NH}_{4}\right)_{6}\left[\mathrm{Mo}_{132} \mathrm{O}_{372}\left(\mathrm{CH}_{3} \mathrm{COO}\right)_{30}\right]$ (left) and $(\text { DODA })_{56}\left(\mathrm{NH}_{4}\right)_{16}\left[\mathrm{Mo}_{132} \mathrm{~S}_{60} \mathrm{O}_{312}\left(\mathrm{SO}_{4}\right)_{30}\right]$ (right at $200{ }^{\circ} \mathrm{C}$; Bottom: schematic representation of the Liquid crystalline organization for both compounds. The $\mathrm{DODA}^{+}$cations are distributed within the layers. The increase of the number of DODA+ cations increases the interlamellar distance from $h$ for $(\text { DODA })_{36}\left(\mathrm{NH}_{4}\right)_{6}\left[\mathrm{Mo}_{132} \mathrm{O}_{372}\left(\mathrm{CH}_{3} \mathrm{COO}\right)_{30}\right]$ to $h$ ' for $(\mathrm{DODA})_{56}\left(\mathrm{NH}_{4}\right)_{16}\left[\mathrm{Mo}_{132} \mathrm{~S}_{60} \mathrm{O}_{312}\left(\mathrm{SO}_{4}\right)_{30}\right]$. (Reprinted from Floquet, Terazzi et al. ${ }^{[82,84]}$ with the permission from the Royal Society of Chemistry) 
These results prompted us to extend our investigation towards other highly charged polyoxometalate systems exhibiting shape anisotropy instead of the spherical keplerate compounds. The cyclic superlacunary anionic POM $\left[\mathrm{H}_{7} \mathrm{P}_{8} \mathrm{~W}_{48} \mathrm{O}_{184}\right]^{33-}$ represents an attractive system. ${ }^{[85]}$ It possesses a large anionic pocket of about $1 \mathrm{~nm}$ in diameter, which is able to include various transition metals, a key step for the elaboration of efficient materials for magnetic, luminescent, catalytic or electrocatalytic properties. ${ }^{[86,}{ }^{87]}$ Additionally, this macrocyclic system can offer promising properties towards the sequestration of various substrates or for catalysis as highlighted by Noro, Cronin and Nakamura with the encapsulation of the gigantic ring-shape cluster $\left[\mathrm{Mo}_{154}(\mathrm{NO})_{14} \mathrm{O}_{448} \mathrm{H}_{14}\left(\mathrm{H}_{2} \mathrm{O}\right)_{70}\right]^{28-}$ with $\mathrm{DODA}^{+}$ cations. $^{[45,88]}$ Following the same strategy, we chose to combine the ring-shape polyoxothiometalate $\left[\left\{\mathrm{Mo}_{4} \mathrm{O}_{4} \mathrm{~S}_{4}\left(\mathrm{H}_{2} \mathrm{O}\right)_{3}(\mathrm{OH})_{2}\right\}_{2}\left(\mathrm{P}_{8} \mathrm{~W}_{48} \mathrm{O}_{184}\right)\right]^{36-}$ (Figure 9) ${ }^{[89]}$ with alkylmethylimidazolium cations $\left[\mathrm{C}_{\mathrm{n}} \mathrm{mim}\right]^{+}$, alkyl chain ranging from $\mathrm{C}_{12}$ to $\mathrm{C}_{20}$, and $\mathrm{DODA}^{+}$ cations. Six new hybrids systems pairing the POM with 19 to 26 organic cations were obtained, the missing charges being ensured by protons and alkali cations trapped within the cavity of the POM. The materials have been analysed by usual techniques. In particular MAS NMR spectra on solid evidenced a dipolar interaction through space between the phosphorous atoms of the POM with some protons of the organic cation, suggesting a very close association between the two components (see Figure 9). All the DODA ${ }^{+}$and $\left[\mathrm{C}_{n} \mathrm{mim}\right]^{+}$salts showed liquid crystal behaviour with a transition temperature ranging from $-3.5^{\circ} \mathrm{C}$ to $+46.2^{\circ} \mathrm{C}$ as a function of the cation, higher temperature being obtained with longer alkyl chains. Polarized optical microscopy and small angle X-ray patterns revealed the formation of smectic phases. Interestingly, at the opposite of the Keplerate-based liquid crystals, the interlayer distances of the $5\left[\mathrm{C}_{\mathrm{n}} \mathrm{mim}\right]^{+}$salts evidenced a perfectly linear dependence with the alkyl chain length (see inset Figure 9 right). In agreement with the work of Kurth and Faul, ${ }^{[73]}$ it suggested that organization of the cations around the POM are done between the layers and that changing the nature of the POM and its anisotropy can induce the formation of different kinds of mesophases. 


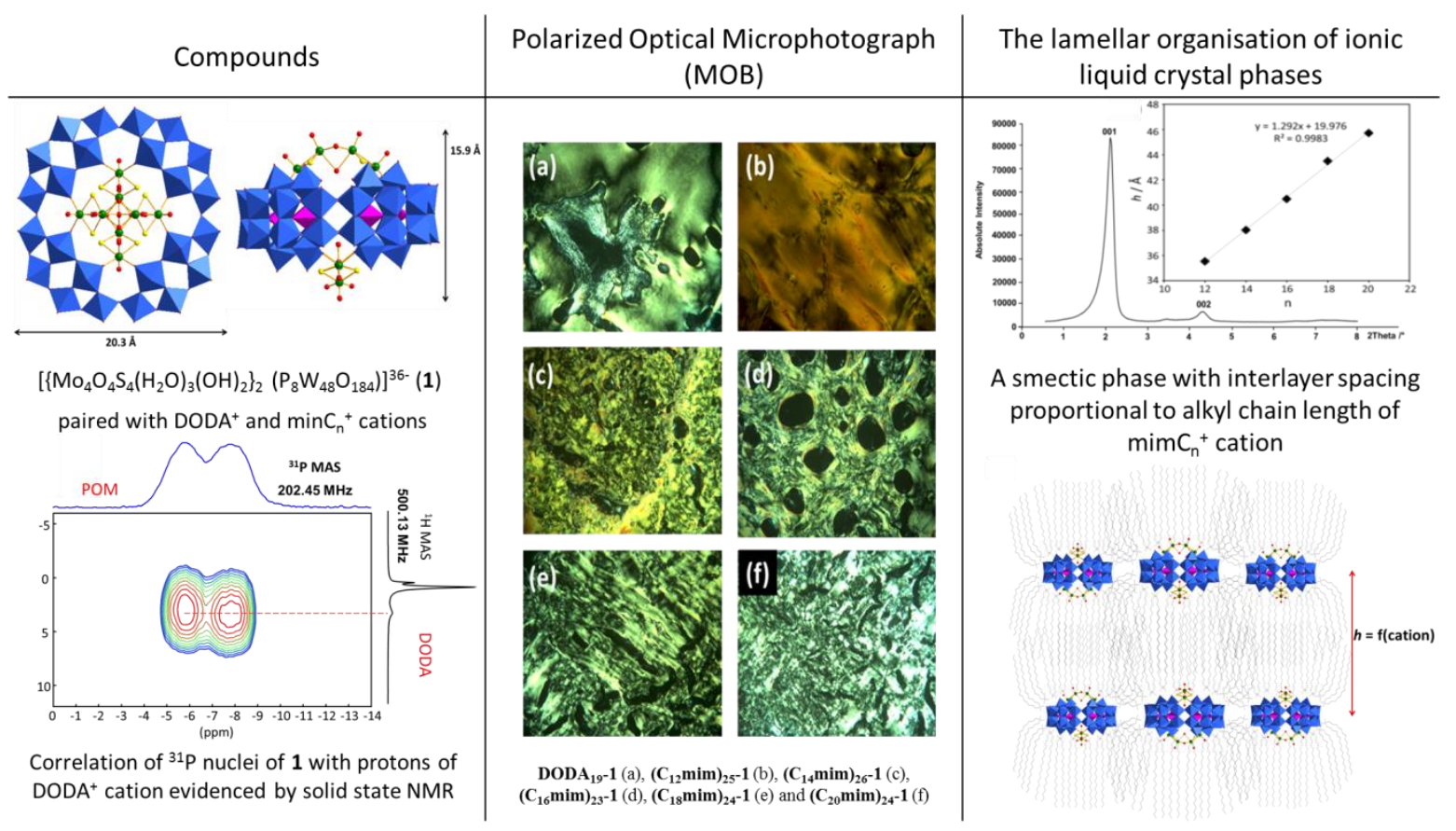

Figure 9. Left: Top and side structural views of the perpendicular isomer of 1 in polyhedral and ball-andstick representation. The $\left\{\mathrm{P}_{8} \mathrm{~W}_{48}\right\}$ moiety is depicted in blue and pink polyhedra, molybdenum in green, sulfur in yellow and oxygen in red; ${ }^{31} \mathrm{P}\left\{{ }^{1} \mathrm{H}\right\}$ Hetcor CPMAS NMR spectra of DODA $19^{-1}$; Middle: Polarized Optical Microphotograph of DODA $19-1$ at $203{ }^{\circ} \mathrm{C}(\mathrm{a}),\left(\mathrm{C}_{12} \mathrm{mim}\right)_{25}-1$ at $240{ }^{\circ} \mathrm{C}(\mathrm{b}),\left(\mathrm{C}_{14} \mathrm{mim}\right)_{26}-1$ at $240{ }^{\circ} \mathrm{C}$ (c), $\left(\mathrm{C}_{16} \mathrm{mim}\right)_{23}-1$ at $240{ }^{\circ} \mathrm{C}(\mathrm{d}),\left(\mathrm{C}_{18} \mathrm{mim}\right)_{24}-1$ at $240{ }^{\circ} \mathrm{C}(\mathrm{e})$ and $\left(\mathrm{C}_{20} \mathrm{mim}\right)_{24}-1$ at $240{ }^{\circ} \mathrm{C}$ (f); Right: SA-XRD pattern recorded at $200{ }^{\circ} \mathrm{C}$ for compound $\left(\mathrm{C}_{16} \mathrm{mim}\right)_{23}-1$; Inset: Linear variation of the averaged value of interlayer spacing has a function of alkyl chain length $n$ in $\left[C_{n} \mathrm{mim}\right]^{+}$cations; Side view of the Schematic representation of the hypothetical organizations of organic cations around the polyanion 1 within the liquid crystal phase. (Reprinted from Floquet, Terazzi et al. ${ }^{[90]}$ with the permission from the Royal Society of Chemistry.)

\section{1-3. An original promising approach by encapsulating akali counter-cations}

In addition to the two previous approaches, Molard and coworkers developed another strategy with hexametallic clusters which consisted in trapping the alkali counter cations, especially $\mathrm{K}^{+}$and $\mathrm{Cs}^{+}$, within functionalized $15 \mathrm{C} 5$ or $18 \mathrm{C} 6$ crown ethers (see Figure 10). ${ }^{[91,}$ ${ }^{92]}$ Following this idea, they succeeded to design columnar hexagonal arrangements mainly due to discotic-like complex formed between the crown ethers and the alkali, while the metallic clusters, well known for their strong luminescence properties, were localized between the columns (see Figure 11). Even if this family of clusters does not formally belong to POM's family, this strategy constitutes a very interesting perspective for developing new POM-based ionic liquid crystals with new arrangements. 
(a)

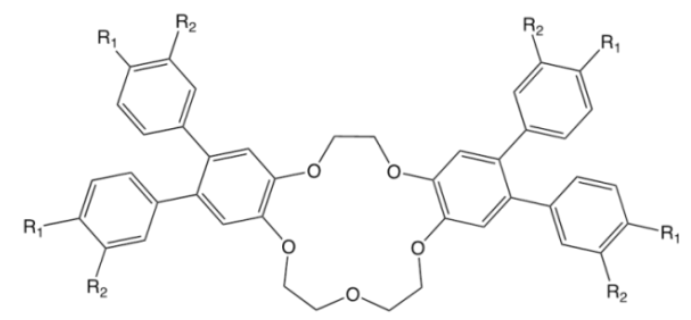

1: $\mathrm{R}_{1}=\mathrm{R}_{2}=\mathrm{OC}_{12} \mathrm{H}_{25}$
$2: \mathrm{R}_{1}=\mathrm{OC}_{12} \mathrm{H}_{25} \mathrm{R}_{2}=\mathrm{SC}_{12} \mathrm{H}_{25}$
$3: \mathrm{R}_{1}=\mathrm{R}_{2}=\mathrm{SC}_{12} \mathrm{H}_{25}$

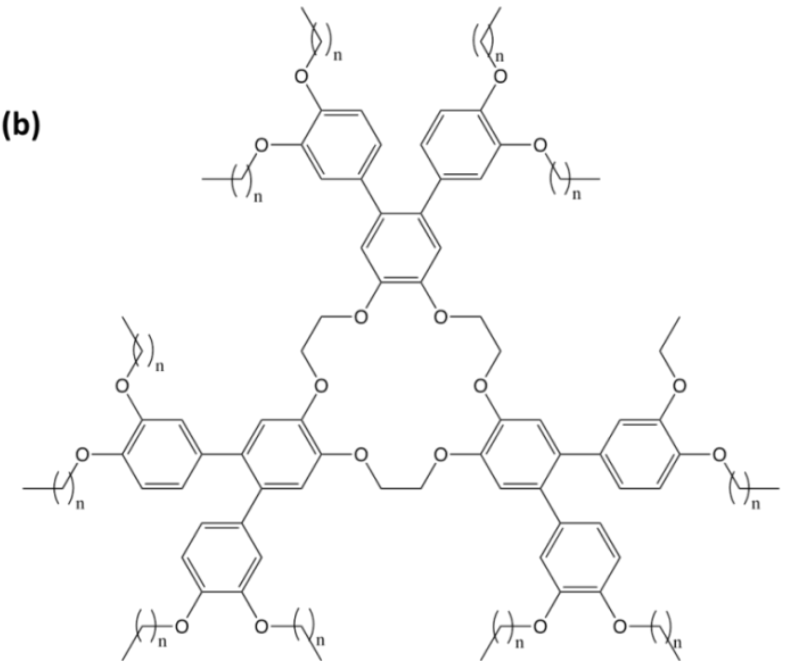

$(\mathrm{n}=7,9,10,11,13,15)$

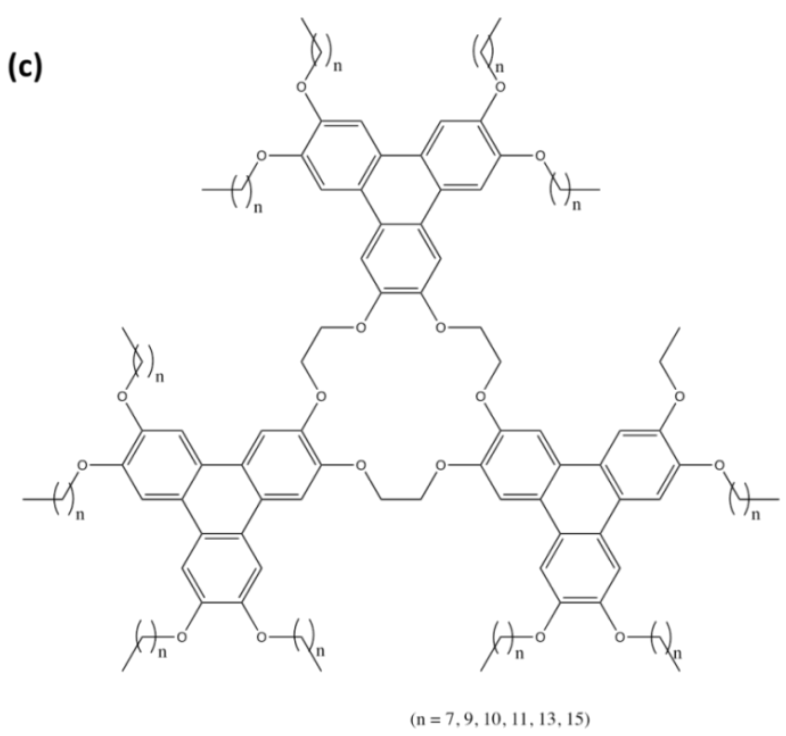

Figure 10. Representation of $15 \mathrm{C5}$ and $18 \mathrm{C} 6$ crown ethers derivatives used by Molard and coworkers to coordinate $\mathrm{K}^{+}$and $\mathrm{Cs}^{+}$counter cations paired with hexametallic clusters $\left[\mathrm{Mo}_{6} \mathrm{X}_{14}\right]^{2-}(\mathrm{X}=\mathrm{Cl}, \mathrm{Br}, \mathrm{I})$ and $\left[\mathrm{Mo}_{6} \mathrm{I}_{8}\left(\mathrm{C}_{2} \mathrm{~F}_{5} \mathrm{COO}\right)_{6}\right]^{2-} \cdot[91,92]$ 

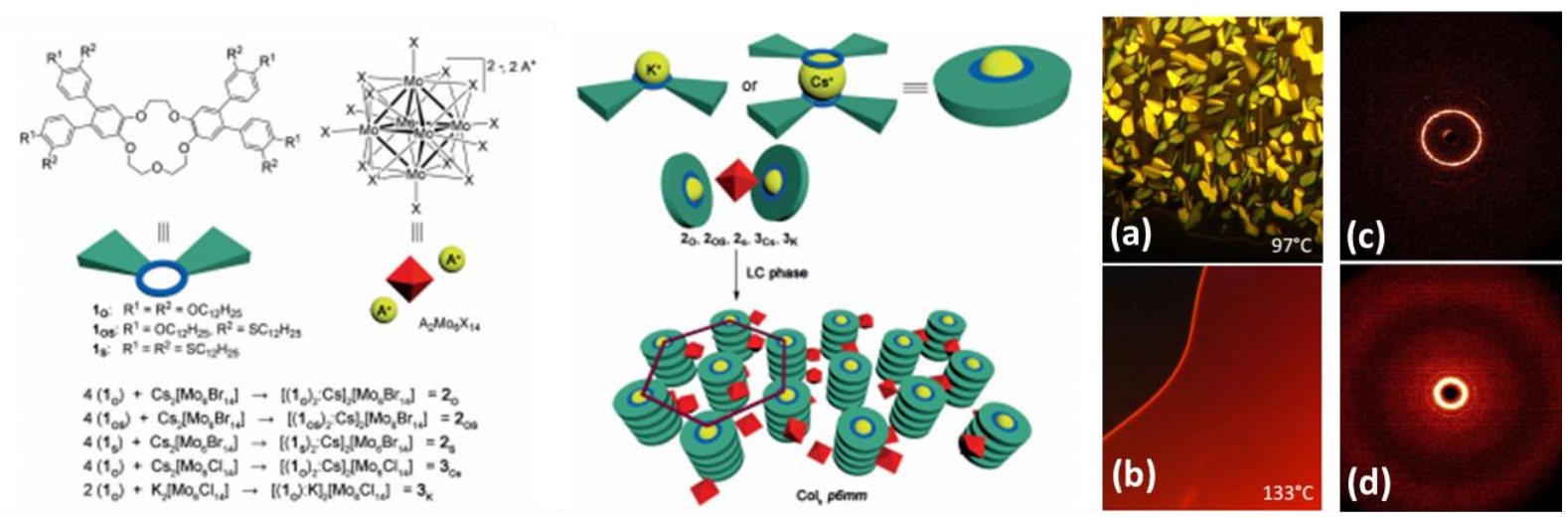

Figure 11: Representation of $15 C 5$ crown ether derivatives, $A_{2} M_{6} X_{14}$ transition metal cluster compound salts, synthesized complexes and hybrids self-arrangement in the liquid crystalline phase. Polarized Optical micrographs under white light or UV irradiation of compounds $2_{0}(a, b)$; 2D SAXS and WAXS patterns recorded in the mesophase for $2_{\mathrm{O}}(\mathrm{c}, \mathrm{d})$. (Reprinted from Molard et al. ${ }^{[91]}$ with the permission from Wiley.)

\section{2- POM-based Ionic Liquids (POM-ILs)}

\section{2-1. Synthesis of true polyoxometalate-ionic liquids (POM-ILs)}

The most simple definition for POM-based ionic liquids (or POM-ILs) is simply POMs paired with an organic counter cations that present a melting temperature below $100{ }^{\circ} \mathrm{C} .{ }^{[40,93-97]}$ Even if almost 550 papers to date are using both "polyoxometalate" and "ionic liquid" words in their keywords or in their title, using typical cations known for giving ionic liquids such as imidazoliums is not enough to enter in the family of true POM-ILs. Many studies report the pairing of organic cations as adjustable counter-cations with POMs, generating an organic/inorganic hybrid material, but most of them are solid salts or materials with a high or even indeterminate melting point and cannot be formally called ionic liquids or POM-ILs. For a better distinction between all the types of association of POM with organic cations, we can define a nomenclature summarized in the table 1. POM-ILs will be used for salts displaying melting point below $100{ }^{\circ} \mathrm{C}$, while IL cation-based POM ionic solids noted IL-POMs are attributed to hybrid salts with higher melting points. POMs, IL-POMs or POM-ILs solubilized in ionic liquid ILs will be noted POM@IL, IL-POM@IL and POM-IL@IL, respectively. In this section, we will focus on POM-ILs. 
Table 1: Nomenclature of POM-based organic cations and definitions:

\begin{tabular}{|lcc|}
\hline Symbol & \multicolumn{1}{c}{ Definition } & Glass transition \\
\hline POM-IL & Real Ionic Liquid with POM anions & $<100{ }^{\circ} \mathrm{C}$ \\
\hline IL-POM & $\begin{array}{c}\text { Salt of organic IL cations and POM } \\
\text { anions }\end{array}$ & $>100^{\circ} \mathrm{C}$ \\
\hline $\begin{array}{l}\text { Ionic Liquid (IL) used as solvent: } \\
\text { POM@IL }\end{array}$ & Acid POM or POM salts in IL & \multirow{2}{*}{$\begin{array}{c}\text { POM-IL@IL } \\
\text { IL-POM@IL }\end{array}$} \\
\cline { 2 - 2 } & POM-IL in IL & \\
\hline
\end{tabular}

The syntheses of POM-ILs are mainly prepared by exchanging protons or the alkali counter cations by an organic one. The simplest method just consists in mixing the POM dissolved in water with the organic salt dissolved in water or in a miscible organic solvent (often an alcohol) in the right stoichiometry. After several hours of reaction under stirring, the two phases are separated and sometimes with the help of centrifugation when emulsions are obtained. The heavy phase can be directly the POM-IL which precipitates or forms a new liquid phase. After several washings, the resulting hybrid POM-IL are dried and analyzed. A second approach follows the strategy of extraction of the POM from water to an organic phase by introduction of a stoichiometric amount or an excess of the organic cations as done for the preparation of Ionic Liquid Crystals. The obtained solids or liquids are standardly characterized by FT-IR spectra, UV-Vis spectra and by NMR techniques in the solid state or in solution. The thermogravimetric analyses (TGA) are of interest to characterize the number of organic cations together with hydration degree and an estimation of thermal stability by combustion of the organic part. The physical properties, and the evidence of ionic liquid phase, involve the use of Differential Thermic Analysis (TDA) or Differential Scanning Calorimetry (DSC) to establish the glass transition temperature $\left(T_{g}\right)$, sometimes difficult to observe since a glass transition does not imply enthalpy variation. It is often associated to visual observations between the two phases and photograph to convince the readers as shown in Figure 12. Furthermore, depending on necessity, other measurements can provide more information to fully characterize the true nature of ionic liquid and its physical properties such as conductivity, viscosity, aggregation morphologies, Polarized optical Microscopy (PM), Scanning Electron Microscope (SEM) image. 
(A)

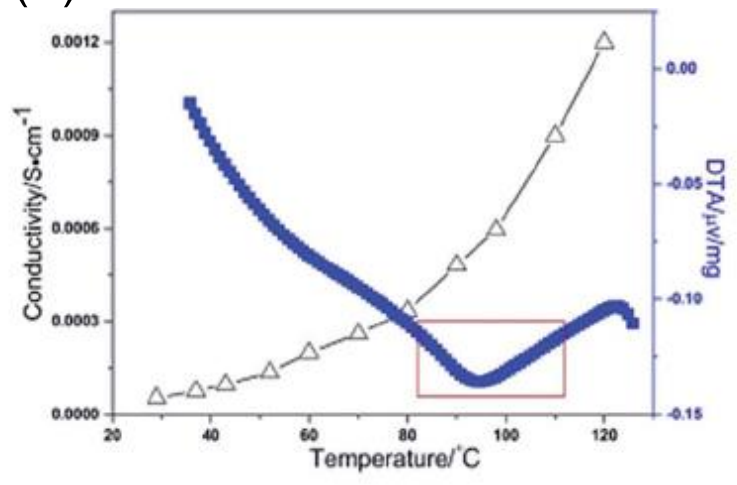

(B)

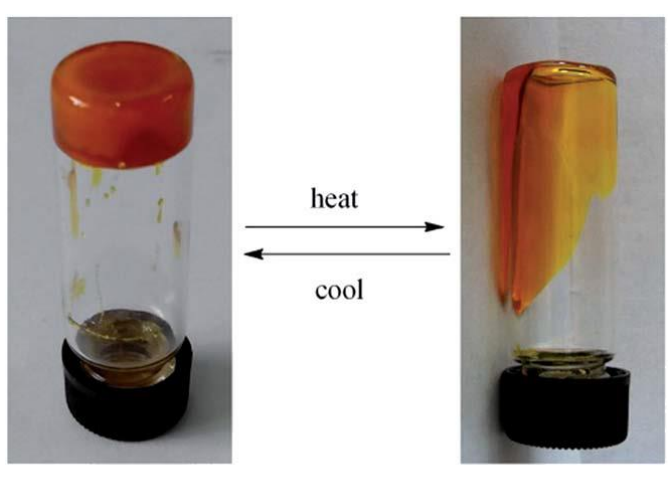

b

Figure 12. Example of characterization of a POM-IL. (A) DTA and conductivity-temperature plots of (PyPS) $)_{4}\left[\mathrm{PMo}_{11} \mathrm{VO}_{40}\right.$, (B) Images of the POM-IL at room temperature in the glass phase and at $95{ }^{\circ} \mathrm{C}$ in the liquid phase. (Reprinted from Wu et al. ${ }^{[98]}$ with the permission from the Royal Society of Chemistry.)

The first report of a true POM-IL was published by Bourlinos et al. in 2004. ${ }^{[99]}$ They presented a polyoxometalate liquid at room temperature $\left(T_{g}\right.$ at $\left.-35{ }^{\circ} \mathrm{C}\right)$, obtained from the reaction of the Keggin anion, $\mathrm{H}_{3}\left[\mathrm{PW}_{12} \mathrm{O}_{40}\right]$ with Ethoquad 18/25 $\left(\left(\mathrm{CH}_{3}\right)\left(\mathrm{C}_{18} \mathrm{H}_{37}\right)\right.$ $\left.\left(\left(\mathrm{CH}_{2} \mathrm{CH}_{2} \mathrm{O}\right) n \mathrm{H}\right)\left(\left(\mathrm{CH}_{2} \mathrm{CH}_{2} \mathrm{O}\right) m \mathrm{H}\right) \mathrm{N}^{+}\right)$, with $m+n=15$, in a ratio $1 / 2$. It displays a high viscosity at room temperature $(75 \mathrm{~Pa} . \mathrm{s})$ which drops to $0.5 \mathrm{~Pa} . \mathrm{s}$ at $120{ }^{\circ} \mathrm{C}$. The thermal stability of this PEGylated POM is not so high with measurable decomposition occurring at only $160{ }^{\circ} \mathrm{C}$. Nevertheless, it constitutes a breakthrough which opened the way to this new family of hybrid catalyst. In 2005 Pai et al, synthesized another POM-IL using aliquat 336 as source of organic cation with a Venturello-type POM (see Figure 13b). ${ }^{[100]}$ The resulting POM-IL $\left(\left(\mathrm{CH}_{3}\right)\left(n-\mathrm{C}_{8} \mathrm{H}_{17}\right)_{3} \mathrm{~N}\right)_{3}\left[\mathrm{PO}_{4}\left[\mathrm{WO}\left(\mathrm{O}_{2}\right)_{2}\right]_{4}\right]$ looks like a yellowish syrup-like substance (Table 2, entry 2). Unfortunately, this methyl-tri- $n$-octylammonium di(diperoxotungsto)hydrophosphate was stable only for 3 days at RT. Later, Dietz et al. designed POM-ILs from simple polyoxotungstates: phosphotungstic acid $\mathrm{H}_{3}\left[\mathrm{PW}_{12} \mathrm{O}_{40}\right]$ and the Lindqvist anion $\left[\mathrm{W}_{6} \mathrm{O}_{19}\right]^{2-}$, with trihexyl(tetradecyl) or tributyl(hexadecyl) phosphonium $\left(\mathrm{P}_{6,6,6,14}{ }^{+}\right.$or $\left.\mathrm{P}_{4,4,4,16}{ }^{+}\right)$cations. ${ }^{[101,102]}$ They highlighted the fact that the long alkyl chain tetraalkylphosphonium derivatives have high thermal stability, suitable conductivity and reversible electrochemical response, low melting temperatures (as low as $-48{ }^{\circ} \mathrm{C}$ for the trihexyl(tetradecyl)phosphonium salt of the Lindqvist isopolyoxoanion, $\left[\mathrm{W}_{6} \mathrm{O}_{19}\right]^{2-}$ (Table 2, entry 6). In 2009, Lixin $\mathrm{Wu}$ and coworkers ${ }^{[103]}$ modified POMs by conveniently exchanging their counterions with cationic surfactants, generating surfactant-encapsulated cluster SEC. By using DODA ${ }^{+}$cation and lacunary Keggin-type POMs $\left(\left[\mathrm{XW}_{11} \mathrm{O}_{39}\right]^{\mathrm{n}-}, \mathrm{X}=\mathrm{P}, \mathrm{Si}, \mathrm{B}, \mathrm{n}=7,8\right.$, 9), or sandwich compounds $\left(\left[\mathrm{Eu}\left(\mathrm{XW}_{11} \mathrm{O}_{39}\right)_{2}\right]^{\mathrm{n}-}, \mathrm{X}=\mathrm{Si}, \mathrm{B}, \mathrm{n}=13,15\right)$. Even if they are solid 
at RT, the $T_{g}$ are below $100{ }^{\circ} \mathrm{C}$ (between $25-45{ }^{\circ} \mathrm{C}$ ) (table 2 entries 7-11). It has been demonstrated, according to the values of $T_{g}$ and the critical gelation concentrations, that the sandwich compounds with lacunary Keggin-type POMs are more efficient gelators than the other POMs of this study. From then and during this work on liquid crystals, a very close neighbor of IL, by using tetra- $n$-octylammonium $\left(\mathrm{TOA}^{+}\right.$) cation associated with Keggin-type polyoxoanions $\left(\left[\mathrm{GeW}_{12} \mathrm{O}_{40}\right]^{4-}\right.$ and $\left.\left[\mathrm{BW}_{12} \mathrm{O}_{40}\right]^{5-}\right)$ two new POM-ILs were reported, with phase transition temperatures of $(\mathrm{TOA})_{5}\left[\mathrm{BW}_{12} \mathrm{O}_{40}\right]$ and $(\mathrm{TOA})_{4}\left[\mathrm{GeW}_{12} \mathrm{O}_{40}\right]$ respectively at $0{ }^{\circ} \mathrm{C}$ and $75^{\circ} \mathrm{C} .{ }^{[75]}$ In $2013, \mathrm{Li}$ and coworkers also used cationic surfactants $\left[\left(\mathrm{C}_{\mathrm{n}} \mathrm{H}_{2 \mathrm{n}+1}\right)_{3} \mathrm{~N}\left(\mathrm{CH}_{3}\right)\right]^{+}$(n = $8,12)$ associated with active peroxo anions $\left\{\mathrm{PO}_{4}\left[\mathrm{MO}\left(\mathrm{O}_{2}\right)_{2}\right]_{4}\right\}^{3-}(\mathrm{M}=\mathrm{W}$, Mo) for oxidative desulfurization. ${ }^{[104]}$ They were all liquid at room temperature (Table 2, entry 14-16) and very efficient extractants and catalysts for the oxidation of dibenzothiophene in model oil using $\mathrm{H}_{2} \mathrm{O}_{2}$ as the oxidant.

In the ionic liquids' field, the most commonly encountered cations are imidazoliums, which prompted many authors to pair POMs with such cations. In 2009, Qiao et al. ${ }^{[105]}$ reported alkylimidazolium polyoxometalates used as catalysts for the epoxidation of olefins. One of them ( $N$-dodecylimidazolium peroxotungstate $\left[\mathrm{HC}_{2} \mathrm{im}\right]_{2}\left[\mathrm{~W}_{2} \mathrm{O}_{11}\right]$ ) revealed to be liquid at room temperature and could be used as a reaction induced phase-separation catalyst, which leads to easy separation of the catalyst from the products via simple decantation. With the same purpose, they developed a POM-IL where the cations were two butylimidazolium linked by a PEG-2000 chain (see Figure 2) and the anionic part was Keggin heteropolyacid $\left(\left[\mathrm{HPW}_{12} \mathrm{O}_{40}\right]^{2-}\right)$ anion. ${ }^{[106]}$ The oxidative esterification was successfully catalyzed by this hybrid compound. In 2011, Cao and Hu chose the lowest charged Lindqvist POM [ $\left.\mathrm{Mo}_{6} \mathrm{O}_{19}\right]^{2-}$ to react with asymmetric 1-methyl-3-octylimidazolium. ${ }^{[107]}$ The polyoxomolybdate-based IL has high stability, a low melting point of $82.6^{\circ} \mathrm{C}$ and its decomposition temperature reaches $321{ }^{\circ} \mathrm{C}$, which is higher than that of 1-octyl-3-methylimidazolium halides IL. They developed analogue polyoxometalate-imidazolium $\left[\mathrm{mimC}_{\mathrm{n}}\right]_{4}\left[\mathrm{Mo}_{8} \mathrm{O}_{26}\right](\mathrm{n}=10$ and 12) with melting points just below the limit of the definition, respectively 94.5 and $95.5{ }^{\circ} \mathrm{C} .{ }^{[108]}$ They all showed good photocatalytic activity for degrading rhodamine B.

In 2014 Qingyin $\mathrm{Wu}$ and his team developed a POM-IL with an imidazolium bearing a sulfonic group (1-(3-sulfonic group)propyl 3-methyl imidazolium (mimPS, see Figure 2)). ${ }^{[109]}$ Earlier Jun Wang tried to synthetize analogue compound (mimPS) $)_{3}\left[\mathrm{PW}_{12} \mathrm{O}_{40}\right]$ as catalyst for esterification but unfortunately it was a solid with a melting point above the $100{ }^{\circ} \mathrm{C}(\mathrm{mp}=$ 119-122 $\left.{ }^{\circ} \mathrm{C}\right) .{ }^{[110]}$ However, when coupled to vanadium substituted Keggin heteropolyanion $\left[\mathrm{PW}_{11} \mathrm{VO}_{40}\right]^{4-}$, the POM-IL possesses a phase transition from a crystal phase to an isotropic 
liquid phase at about $82.4^{\circ} \mathrm{C}$. This material exhibits higher conductivity $\left(8.60 * 10^{-2} \mathrm{~S}^{\mathrm{cm}} \mathrm{cm}^{-1}\right.$ at $83{ }^{\circ} \mathrm{C}$ and $80 \%$ relative humidity) than that of its solid analogue and displays the advantages of both liquid electrolyte and solid-state electrolyte. ${ }^{[110]}$ They extended their studies to three different vanadium-substituted heteropoly anions. ${ }^{[111]}$ The POM-ILs (mimPS) $5\left[\mathrm{SiW}_{11} \mathrm{VO}_{40}\right]$, $(\operatorname{mimPS})_{5}\left[\mathrm{SiMo}_{11} \mathrm{VO}_{40}\right]$ and $(\operatorname{mimPS})_{7}\left[\mathrm{SiW}_{9} \mathrm{~V}_{3} \mathrm{O}_{40}\right]$, exhibit a gel state at room temperature and possess temperature-dependent behavior with a phase transition from the gel state to the liquid state below $100{ }^{\circ} \mathrm{C}$. (Table 2 entries 23-25). Their electrochemical performance varies widely depending on the chemical composition of the heteropolyanions. As expected, the mono-vanadium substituted POM-IL that contained Mo atoms exhibited greater oxidizability than the W-containing one under the same conditions. In addition, more vanadium atoms enhanced the oxidizability of the compounds. In the same time, they explored other various vanadium-substituted heteropolyanion $\left(\left[\mathrm{PW}_{9} \mathrm{~V}_{3} \mathrm{O}_{40}\right]^{6-},\left[\mathrm{PW}_{11} \mathrm{VO}_{40}\right]^{4-},\left[\mathrm{PMo}_{11} \mathrm{VO}_{40}\right]^{4-}\right.$ and $\left.\left[\mathrm{P}_{2} \mathrm{~W}_{17} \mathrm{VO}_{62}\right]^{7-}\right)$. When associated with (1-(3-sulfopropyl)pyridinium cation, the phase transition is between 82 to $103{ }^{\circ} \mathrm{C}$ (Table 2, entries 26-29). ${ }^{[98]}$ This series of POM-ILs compounds shows high conductivity which increases with temperature. This phenomenon can be attributed to an increase in the migration of ions in the compound. In parallel they run the same kind of studies using ammonium or phosphonium cations with long alkyl chains. ${ }^{[12-114]}$ Many of them enter easily in the POM-ILs' family (Table 2 entries 30-36). Phosphoniumbased POM-ILs exhibit higher thermal stability and conductivity than their ammonium analogue. Meanwhile, there is clearly a structure effect on the physicochemical properties: as the size of heteropolyanions increases, there is a significant improvement in the conductivity, thermal performance, and oxidizability, with a lower melting point for these POM/IL gels. During the same period Thangadurai and Tong ${ }^{[15]}$ synthetized analogue POM-ILs $(\operatorname{mimPS})_{4}\left[\mathrm{PMo}_{11} \mathrm{VO}_{40}\right]$ and $(\operatorname{mimPS})_{3}\left[\mathrm{PW}_{11} \mathrm{MoO}_{40}\right]$ that were very viscous at room temperature. They showed high ionic conductivity and a wide electrochemical stability window (respectively about 2 and $4 \mathrm{~V}$ at room temperature) compared to other known ILbased electrolytes. In 2011, new guanidinium phosphotungstates with the $\left[\mathrm{PW}_{12} \mathrm{O}_{40}\right]^{3-}$ anion were synthesized and characterized by Döring's group (Table 2 entries 39-40). ${ }^{[16]}$ They exhibited remarkable activity in epoxidation reactions with $\mathrm{H}_{2} \mathrm{O}_{2}$ and their performances were better than the corresponding ammonium salts.

Studies involving the lacunary Keggin-anion $\left[\alpha-\mathrm{SiW}_{11} \mathrm{O}_{39}\right]^{8-}$ and its transition metal derivatives $\left[\mathrm{SiW}_{11} \mathrm{O}_{39} \mathrm{M}\left(\mathrm{H}_{2} \mathrm{O}\right)\right]^{\mathrm{n}-}\left(\mathrm{M}=\mathrm{Fe}^{\mathrm{III}}, \mathrm{Cu}^{\mathrm{II}}, \mathrm{Mn}^{\mathrm{II}}, \mathrm{Co}^{\mathrm{II}}, \mathrm{Cr}^{\mathrm{III}}, \mathrm{Ni}^{\mathrm{II}}\right)$ with long tetraalkylammonium chain, have recently been reported by Streb and co-workers. ${ }^{[117-122]}$ Most of them revealed low melting point POM-IL and found applications for depollution, 
anticorrosion or biology (Table 2 entries 41-53). Meanwhile, Cavaleiro et al. extended this family of POM-ILs by changing the silicotungstate to transition metal-substituted phosphotungstates with trihexyl(tetradecyl)phosphonium $\left(\mathrm{P}_{6,6,6,14}{ }^{+}\right)$cations. These compounds were viscous liquids at room temperature and, for example, $\left(\mathrm{P}_{6,6,6,14}\right)_{4}\left[\mathrm{PW}_{11} \mathrm{O}_{39} \mathrm{Fe}\left(\mathrm{H}_{2} \mathrm{O}\right)\right]$ presents a typical glass transition temperature of $-24.6{ }^{\circ} \mathrm{C}^{[123]}$ while $\mathrm{TOA}^{+}$salts of $\left[\mathrm{PW}_{11} \mathrm{O}_{39} \mathrm{M}\left(\mathrm{H}_{2} \mathrm{O}\right)\right]^{4-/ 5-}(\mathrm{M}=\mathrm{Mn}, \mathrm{Fe}, \mathrm{Co}, \mathrm{Ni}, \mathrm{Cu}, \mathrm{Zn})$ obtained by Shakeela et ${ }^{\left[{ }^{[124]}\right.}{ }^{\text {displayed }}$ melting points in the range $87-108^{\circ} \mathrm{C}$. Table 2 tries to gather an exhaustive list of true POMILs identified in the literature.

Table 2. List of real POM-ILs found in the literature

\begin{tabular}{|c|c|c|c|}
\hline entry & POM-IL & Melting range $\left({ }^{\circ} \mathrm{C}\right)$ & ref \\
\hline 1 & $\left(\left(\left(\mathrm{CH}_{3}\right)\left(\mathrm{C}_{18} \mathrm{H}_{37}\right)\left[\left(\mathrm{CH}_{2} \mathrm{CH}_{2} \mathrm{O}\right) n \mathrm{H}\right)\left(\left(\mathrm{CH}_{2} \mathrm{CH}_{2} \mathrm{O}\right) m \mathrm{H}\right) \mathrm{N}\right)_{2} \mathrm{H}\left[\mathrm{PW}_{12} \mathrm{O}_{40}\right]\right.$ & -35 & [99] \\
\hline 2 & $\left(\mathrm{Me}\left(n-\mathrm{C}_{8} \mathrm{H}_{17}\right)_{3} \mathrm{~N}\right)_{3}\left[\mathrm{PO}_{4}\left[\mathrm{WO}\left(\mathrm{O}_{2}\right)_{2}\right]_{4}\right]$ & RT-IL & [100] \\
\hline 3 & $\left(\mathrm{C}_{5} \mathrm{H}_{5}\left(n-\mathrm{C}_{16} \mathrm{H}_{33}\right)_{3} \mathrm{~N}\right)_{3}\left[\mathrm{PO}_{4}\left[\mathrm{WO}\left(\mathrm{O}_{2}\right)_{2}\right]_{4}\right]$ & $65-68$ & {$[100]$} \\
\hline 4 & $\left(\left(n-\mathrm{C}_{10} \mathrm{H}_{21}\right)\left(n-\mathrm{C}_{4} \mathrm{H}_{9}\right)_{3} \mathrm{P}^{+}\right)_{2}\left[\mathrm{~W}_{6} \mathrm{O}_{19}\right]$ & 55 & {$[101,102]$} \\
\hline 5 & $\left(\left(n-\mathrm{C}_{14} \mathrm{H}_{27}\right)\left(n-\mathrm{C}_{6} \mathrm{H}_{13}\right)_{3} \mathrm{P}^{+}\right)_{3}\left[\mathrm{PW}_{12} \mathrm{O}_{40}\right]$ & 65 & {$[101,102]$} \\
\hline 6 & $\left(\left(n-\mathrm{C}_{14} \mathrm{H}_{27}\right)\left(n-\mathrm{C}_{6} \mathrm{H}_{13}\right)_{3} \mathrm{P}^{+}\right)_{2}\left[\mathrm{~W}_{6} \mathrm{O}_{19}\right]$ & -48 & {$[101,102]$} \\
\hline 7 & $(\mathrm{DODA})_{7}\left[\mathrm{PW}_{11} \mathrm{O}_{39}\right]$ & 42 & [103] \\
\hline 8 & $(\mathrm{DODA})_{8}\left[\mathrm{SiW}_{11} \mathrm{O}_{39}\right]$ & 37 & [103] \\
\hline 9 & $(\mathrm{DODA})_{9}\left[\mathrm{BW}_{11} \mathrm{O}_{39}\right]$ & 34 & [103] \\
\hline 10 & $(\mathrm{DODA})_{13}\left[\mathrm{Eu}\left(\mathrm{SiW}_{11} \mathrm{O}_{39}\right)_{2}\right]$ & 27 & [103] \\
\hline 11 & $(\mathrm{DODA})_{15}\left[\mathrm{Eu}\left(\mathrm{BW}_{11} \mathrm{O}_{39}\right)_{2}\right]$ & 32 & [103] \\
\hline 12 & $(\mathrm{TOA})_{5}\left[\mathrm{BW}_{12} \mathrm{O}_{40}\right]$ & 0 & [75] \\
\hline 13 & $(\mathrm{TOA})_{4}\left[\mathrm{GeW}_{12} \mathrm{O}_{40}\right]$ & 75 & [75] \\
\hline 14 & $\left(\left(n-\mathrm{C}_{8} \mathrm{H}_{17}\right)_{3} \mathrm{NCH}_{3}\right)_{3}\left[\mathrm{PO}_{4}\left(\mathrm{MoO}\left(\mathrm{O}_{2}\right)_{2}\right)_{4}\right]$ & RT-IL & [104] \\
\hline 15 & $\left(\left(\mathrm{n}-\mathrm{C}_{12} \mathrm{H}_{25}\right)_{3} \mathrm{NCH}_{3}\right)_{3}\left[\mathrm{PO}_{4}\left(\mathrm{MoO}\left(\mathrm{O}_{2}\right)_{2}\right)_{4}\right]$ & RT-IL & [104] \\
\hline 16 & $\left(\left(n-\mathrm{C}_{8} \mathrm{H}_{17}\right)_{3} \mathrm{NCH}_{3}\right)_{3}\left[\mathrm{PO}_{4}\left[\mathrm{WO}\left(\mathrm{O}_{2}\right)_{2}\right]_{4}\right]$ & RT-IL & [104] \\
\hline 17 & $\left(\mathrm{HC}_{12} \mathrm{im}\right)_{2}\left[\mathrm{~W}_{2} \mathrm{O}_{11}\right]$ & RT-IL & [105] \\
\hline 18 & $\left.\mathrm{~N}^{+}+\gamma_{0}-\chi_{\mathrm{N}}^{+} \stackrel{+=}{\mathrm{N}}=\mathrm{N}^{-\mathrm{C}_{4} \mathrm{H}_{9}}\right)\left(\mathrm{HPW}_{10} \mathrm{O}_{40}{ }^{2-}\right)$ & RT-IL & {$[106]$} \\
\hline 19 & $\left(\mathrm{C}_{8} \mathrm{mim}\right)_{2}\left[\mathrm{Mo}_{6} \mathrm{O}_{19}\right]$ & 82.6 & [107] \\
\hline
\end{tabular}




\begin{tabular}{|c|c|c|c|}
\hline 20 & $\left(\mathrm{C}_{10} \mathrm{mim}\right)_{4}\left[\mathrm{Mo}_{8} \mathrm{O}_{26}\right]$ & 94.5 & [108] \\
\hline 21 & $\left(\mathrm{C}_{12} \mathrm{mim}\right)_{4}\left[\mathrm{Mo}_{8} \mathrm{O}_{26}\right]$ & 95.5 & [108] \\
\hline 22 & $(\operatorname{mimPS})_{4}\left[\mathrm{PW}_{11} \mathrm{VO}_{40}\right]$ & 83 & [109] \\
\hline 23 & $(\operatorname{mimPS})_{5}\left[\mathrm{SiW}_{11} \mathrm{VO}_{40}\right]$ & 87 & [111] \\
\hline 24 & $(\operatorname{mimPS})_{5}\left[\mathrm{SiMo}_{11} \mathrm{VO}_{40}\right]$ & 95 & [111] \\
\hline 25 & $(\operatorname{mimPS})_{7}\left[\mathrm{SiW}_{9} \mathrm{~V}_{3} \mathrm{O}_{40}\right]$ & 91 & [111] \\
\hline 26 & $(\mathrm{PyPS})_{6}\left[\mathrm{PW}_{9} \mathrm{~V}_{3} \mathrm{O}_{40}\right]$ & 84 & [98] \\
\hline 27 & $(\mathrm{PyPS})_{4}\left[\mathrm{PW}_{11} \mathrm{VO}_{40}\right]$ & 103 & [98] \\
\hline 28 & $(\mathrm{PyPS})_{4}\left[\mathrm{PMo}_{11} \mathrm{VO}_{40}\right]$ & 92 & [98] \\
\hline 29 & $(\mathrm{PyPS})_{7}\left[\mathrm{P}_{2} \mathrm{~W}_{17} \mathrm{VO}_{62}\right]$ & 82 & [98] \\
\hline 30 & $\left(\left(n-\mathrm{C}_{14} \mathrm{H}_{27}\right)\left(n-\mathrm{C}_{4} \mathrm{H}_{9}\right)_{3} \mathrm{~N}^{+}\right)_{6}\left[\mathrm{PW}_{9} \mathrm{~V}_{3} \mathrm{O}_{40}\right]$ & 88 & [112] \\
\hline 31 & $\left(\left(n-\mathrm{C}_{14} \mathrm{H}_{27}\right)\left(n-\mathrm{C}_{4} \mathrm{H}_{9}\right)_{3} \mathrm{P}^{+}\right)_{6}\left[\mathrm{PW}_{9} \mathrm{~V}_{3} \mathrm{O}_{40}\right]$ & 92 & [112] \\
\hline 32 & $\left(\left(n-\mathrm{C}_{14} \mathrm{H}_{27}\right)\left(n-\mathrm{C}_{4} \mathrm{H}_{9}\right)_{3} \mathrm{~N}^{+}\right)_{5}\left[\mathrm{SiW}_{11} \mathrm{VO}_{40}\right]$ & 80 & [113] \\
\hline 33 & $\left(\left(n-\mathrm{C}_{10} \mathrm{H}_{21}\right)\left(n-\mathrm{C}_{4} \mathrm{H}_{9}\right)_{3} \mathrm{~N}^{+}\right)_{5}\left[\mathrm{SiW}_{11} \mathrm{VO}_{40}\right]$ & 95 & [113] \\
\hline 34 & $\left(\left(n-\mathrm{C}_{14} \mathrm{H}_{27}\right)\left(n-\mathrm{C}_{4} \mathrm{H}_{9}\right)_{3} \mathrm{P}^{+}\right)_{5}\left[\mathrm{SiW}_{11} \mathrm{VO}_{40}\right]$ & 50 & [113] \\
\hline 35 & $\left(\left(n-\mathrm{C}_{14} \mathrm{H}_{27}\right)\left(n-\mathrm{C}_{4} \mathrm{H}_{9}\right)_{3} \mathrm{P}^{+}\right)_{8}\left[\mathrm{P}_{2} \mathrm{~W}_{16} \mathrm{~V}_{2} \mathrm{O}_{62}\right]$ & 50 & [114] \\
\hline 36 & $\left(\left(n-\mathrm{C}_{14} \mathrm{H}_{27}\right)\left(n-\mathrm{C}_{4} \mathrm{H}_{9}\right)_{3} \mathrm{P}^{+}\right)_{8}\left[\mathrm{PW}_{10} \mathrm{~V}_{2} \mathrm{O}_{40}\right]$ & 61 & [114] \\
\hline 37 & $(\operatorname{mimPS})_{4}\left[\mathrm{PMo}_{11} \mathrm{VO}_{40}\right]$ & RT-IL & [115] \\
\hline 38 & $(\operatorname{mimPS})_{3}\left[\mathrm{PW}_{11} \mathrm{MoO}_{40}\right]$ & RT-IL & [115] \\
\hline 39 & $\left(\mathrm{~N}, \mathrm{~N}, \mathrm{~N}, \mathrm{~N}^{\prime}-\left(n-\mathrm{C}_{6} \mathrm{H}_{13}\right)_{4}-\mathrm{N}^{\prime},{ }^{\prime}, \mathrm{N}^{\prime}-\mathrm{CH}_{3}\right)_{2}$ guanidinium $)_{3}\left[\mathrm{PW}_{12} \mathrm{O}_{40}\right]$ & 91 & [116] \\
\hline 40 & $\left(\mathrm{~N}, \mathrm{~N}, \mathrm{~N}^{\prime}, \mathrm{N}^{\prime}-\left(n-\mathrm{C}_{8} \mathrm{H}_{17}\right)_{4}-\mathrm{N}^{\prime}{ }^{\prime}, \mathrm{N}^{\prime}{ }^{\prime}-\left(\mathrm{CH}_{3}\right)_{2} \text { guanidinium }\right)_{3}\left[\mathrm{PW}_{12} \mathrm{O}_{40}\right]$ & 73 & [116] \\
\hline 41 & $\left(\left(n-\mathrm{C}_{6} \mathrm{H}_{13}\right)_{4} \mathrm{~N}^{+}\right)_{8}\left[\alpha-\mathrm{SiW}_{11} \mathrm{O}_{39}\right]$ & RT-IL & [119] \\
\hline 42 & $\left(\left(n-\mathrm{C}_{7} \mathrm{H}_{15}\right)_{4} \mathrm{~N}^{+}\right)_{8}\left[\alpha-\mathrm{SiW}_{11} \mathrm{O}_{39}\right]$ & 68 & {$[119,120,122]$} \\
\hline 43 & $(\mathrm{TOA})_{8}\left[\alpha-\mathrm{SiW}_{11} \mathrm{O}_{39}\right]$ & 70 & [120] \\
\hline 44 & $\left(\left(n-\mathrm{C}_{6} \mathrm{H}_{13}\right)_{3}\left(n-\mathrm{C}_{14} \mathrm{H}_{29}\right) \mathrm{N}^{+}\right)_{8}\left[\alpha-\mathrm{SiW}_{11} \mathrm{O}_{39}\right]$ & RT-IL & [122] \\
\hline 45 & $\left(\left(n-\mathrm{C}_{6} \mathrm{H}_{13}\right)_{4} \mathrm{~N}^{+}\right)_{5}\left[\alpha-\mathrm{SiW}_{11} \mathrm{O}_{39} \mathrm{Fe}\left(\mathrm{H}_{2} \mathrm{O}\right)\right]$ & $78-90$ & [117] \\
\hline 46 & $\left(\left(n-\mathrm{C}_{7} \mathrm{H}_{15}\right)_{4} \mathrm{~N}^{+}\right)_{5}\left[\alpha-\mathrm{SiW}_{11} \mathrm{O}_{39} \mathrm{Fe}\left(\mathrm{H}_{2} \mathrm{O}\right)\right]$ & 27 & {$[117,118]$} \\
\hline 47 & $\left(\left(n-\mathrm{C}_{8} \mathrm{H}_{17}\right)_{4} \mathrm{~N}^{+}\right)_{5}\left[\alpha-\mathrm{SiW}_{11} \mathrm{O}_{39} \mathrm{Fe}\left(\mathrm{H}_{2} \mathrm{O}\right)\right]$ & $-59--40$ & {$[117,118]$} \\
\hline 48 & $\left(\left(n-\mathrm{C}_{7} \mathrm{H}_{15}\right)_{4} \mathrm{~N}^{+}\right)_{6}\left[\alpha-\mathrm{SiW}_{11} \mathrm{O}_{39} \mathrm{Cu}\left(\mathrm{H}_{2} \mathrm{O}\right)\right]$ & 27 & {$[117,118]$} \\
\hline
\end{tabular}




\begin{tabular}{|c|c|c|c|}
\hline 49 & $\left(\left(n-\mathrm{C}_{8} \mathrm{H}_{17}\right)_{4} \mathrm{~N}^{+}\right)_{6}\left[\alpha-\mathrm{SiW}_{11} \mathrm{O}_{39} \mathrm{Cu}\left(\mathrm{H}_{2} \mathrm{O}\right)\right]$ & -34 & {$[117,118]$} \\
\hline 50 & $\left(\left(n-\mathrm{C}_{7} \mathrm{H}_{15}\right)_{4} \mathrm{~N}^{+}\right)_{6}\left[\alpha-\mathrm{SiW}_{11} \mathrm{O}_{39} \mathrm{Co}\left(\mathrm{H}_{2} \mathrm{O}\right)\right]$ & $-70-0$ & [117] \\
\hline 51 & $\left(\left(n-\mathrm{C}_{7} \mathrm{H}_{15}\right)_{4} \mathrm{~N}^{+}\right)_{6}\left[\alpha-\mathrm{SiW}_{11} \mathrm{O}_{39} \mathrm{Ni}\left(\mathrm{H}_{2} \mathrm{O}\right)\right]$ & 24 & [117] \\
\hline 52 & $\left(\left(n-\mathrm{C}_{7} \mathrm{H}_{15}\right)_{4} \mathrm{~N}^{+}\right)_{5}\left[\alpha-\mathrm{SiW}_{11} \mathrm{O}_{39} \mathrm{Cr}\left(\mathrm{H}_{2} \mathrm{O}\right)\right]$ & $-70-0$ & [117] \\
\hline 53 & $\left(\left(n-\mathrm{C}_{7} \mathrm{H}_{15}\right)_{4} \mathrm{~N}^{+}\right)_{5}\left[\alpha-\mathrm{SiW}_{11} \mathrm{O}_{39} \mathrm{Mn}\left(\mathrm{H}_{2} \mathrm{O}\right)\right]$ & $-70-0$ & [117] \\
\hline 54 & $\left(\mathrm{P}_{6,6,6,14}{ }^{+}\right)_{4}\left[\mathrm{PW}_{11} \mathrm{O}_{39} \mathrm{Fe}\left(\mathrm{H}_{2} \mathrm{O}\right)\right]$ & -24.6 & [123] \\
\hline 55 & $\left(\mathrm{P}_{6,6,6,14}^{+}\right)_{5}\left[\mathrm{PW}_{11} \mathrm{O}_{39} \mathrm{Co}\left(\mathrm{H}_{2} \mathrm{O}\right)\right]$ & -25 & [123] \\
\hline 56 & $\left(\mathrm{P}_{6,6,6,14}^{+}\right)_{4}\left[\mathrm{PW}_{11} \mathrm{O}_{39} \mathrm{Mn}\left(\mathrm{H}_{2} \mathrm{O}\right)\right]$ & RT-IL & [123] \\
\hline 57 & $(\mathrm{TOA})_{5}\left[\mathrm{PW}_{11} \mathrm{O}_{39} \mathrm{Mn}\left(\mathrm{H}_{2} \mathrm{O}\right)\right]$ & $40-87$ & [124] \\
\hline 58 & $(\mathrm{TOA})_{4}\left[\mathrm{PW}_{11} \mathrm{O}_{39} \mathrm{Fe}\left(\mathrm{H}_{2} \mathrm{O}\right)\right]$ & $40-108$ & [124] \\
\hline 59 & $(\mathrm{TOA})_{5}\left[\mathrm{PW}_{11} \mathrm{O}_{39} \mathrm{Co}\left(\mathrm{H}_{2} \mathrm{O}\right)\right]$ & $40-87$ & [124] \\
\hline 60 & $(\mathrm{TOA})_{5}\left[\mathrm{PW}_{11} \mathrm{O}_{39} \mathrm{Ni}\left(\mathrm{H}_{2} \mathrm{O}\right)\right]$ & $40-87$ & [124] \\
\hline 61 & $(\mathrm{TOA})_{5}\left[\mathrm{PW}_{11} \mathrm{O}_{39} \mathrm{Cu}\left(\mathrm{H}_{2} \mathrm{O}\right)\right]$ & $40-87$ & [124] \\
\hline 62 & $(\mathrm{TOA})_{5}\left[\mathrm{PW}_{11} \mathrm{O}_{39} \mathrm{Zn}\left(\mathrm{H}_{2} \mathrm{O}\right)\right]$ & $40-87$ & [124] \\
\hline 63 & $\left.\left(\left(n-\mathrm{C}_{7} \mathrm{H}_{15}\right)_{4} \mathrm{~N}^{+}\right)_{5}\left[\mathrm{PW}_{11} \mathrm{O}_{39} \mathrm{RhCH}_{2} \mathrm{CO}_{2} \mathrm{H}\right)\right]$ & 73 & [78] \\
\hline
\end{tabular}

\section{2-2. Applications of POM-ILs}

As mentioned in the previous sections, the synthesis of POM-ILs materials is driven by applications in different fields, especially for catalysis but not only.

\section{2-2-1 Applications in Catalysis}

Real POM-ILs liquid at $100{ }^{\circ} \mathrm{C}$ are not so often used in catalytic reaction. ${ }^{[97]}$ This part is mainly focused on POM-ILs catalysts and it is extended to the solid salts IL-POMs catalysts that form liquid phase in the reaction conditions. In fact, for catalytic oxidation, hydrogen peroxide is the common oxidant used, so the problem of solubility of the organic reactants is present. Biphasic or triphasic systems are reported at the initial state even with amphiphilic or surfactant cations. In the reaction conditions, liquid phases can be formed and after consumption of $\mathrm{H}_{2} \mathrm{O}_{2}$ and cooling, the catalyst often precipitates, which offers the properties of homogeneous reaction and heterogeneous separation. Another point to be considered is the stability and the reactivity of POM with $\mathrm{H}_{2} \mathrm{O}_{2}$. Especially for tungstic POMs with Lindqvist structure, no oxidant properties are expected. ${ }^{[125]}$ For POM with Keggin structure the $\mathrm{W}^{6+} / \mathrm{W}^{5+}$ 
that has negative redox potential, high catalytic performances are nevertheless reported. Thus, it has been admitted that these compounds are precursors for the formation of active peroxospecies. ${ }^{[97]}$ Two very active species were reported and characterized $\left[\mathrm{PO}_{4}\left\{\mathrm{WO}\left(\mathrm{O}_{2}\right)_{2}\right\}_{4}\right]^{3-}$ and $\left[\left\{\mathrm{WO}\left(\mathrm{O}_{2}\right)_{2}\right\}_{2} \mu \mathrm{O}_{2}\right]^{2-}$ (see Figure 13) but many other species can be formed. ${ }^{[100]}$ Finally, the degradation of $\mathrm{H}_{2} \mathrm{O}_{2}$ in $\mathrm{O}_{2}$ has to be considered mainly for safety purposes in order to limit the formation of explosive atmosphere and it is known that peroxotungstates are more inactive than molybdic or vanadic analogues. ${ }^{[97]}$
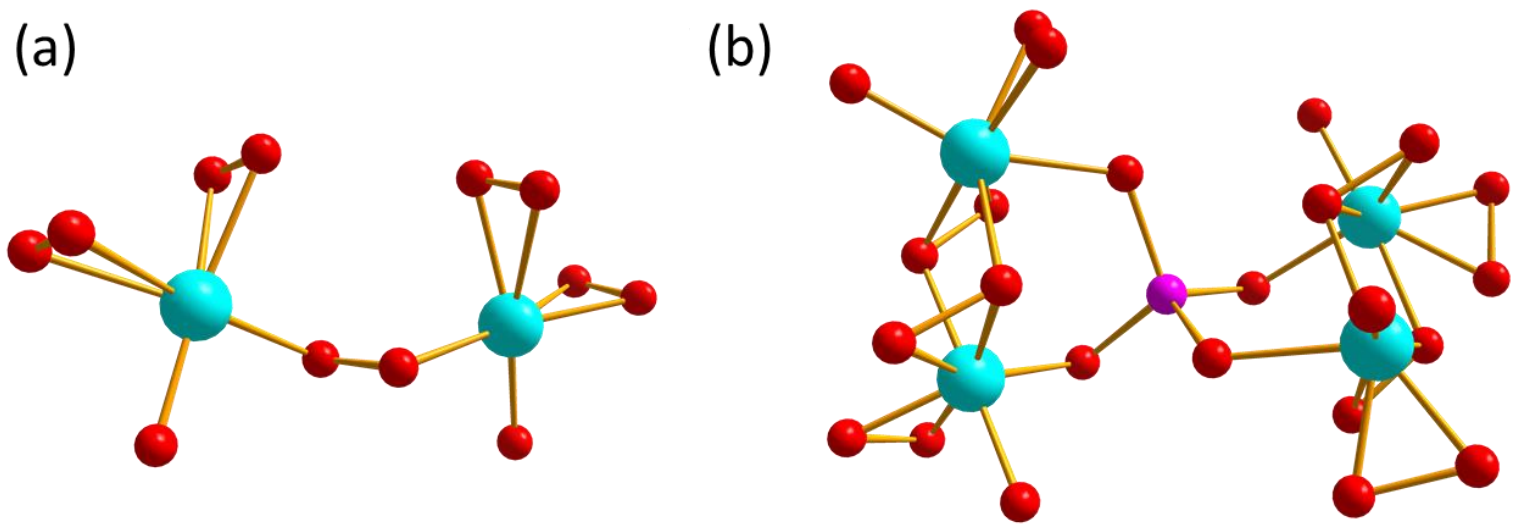

Figure 13. Representation of peroxo complexes $\left[\left\{\mathrm{WO}\left(\mathrm{O}_{2}\right)_{2}\right\}_{2} \mu \mathrm{O}_{2}\right]^{2-}$ (a) and $\left[\mathrm{PO}_{4}\left\{\mathrm{WO}\left(\mathrm{O}_{2}\right)_{2}\right\}_{4}\right]^{3-}(\mathrm{b})$ with the corresponding atomic color: Tungsten in blue, phosphorous in purple and oxygen in red.

In this part we report the results by type of reaction performed without addition of other IL and in solvent free conditions.

\section{- Alcohols oxidation}

Alcohol oxidation with hydrogen peroxide is the one of the most studied reaction without additional solvent. The difference of aqueous solubility between the reactant and the products can be considered and only IL-POMs are reported. They act as transfer agent in catalytic condition in presence of $\mathrm{H}_{2} \mathrm{O}_{2}$ forming homogeneous phases or emulsion. After cooling, generally the POM catalyst is easily recovered by centrifugation and it can be reused several times.

Importance of the reactant has been studied by D. Liu et al. ${ }^{[126]}$ Furthermore, they developed a new method to obtain in a one-pot synthesis a decatungstate $\left(\left[\mathrm{W}_{10} \mathrm{O}_{32}\right]^{4-}\right)$ based IL-POM starting from sodium tungstate and bisulfate-based ionic liquids (N-butylpyridinium bisulfate 
$[\mathrm{bPy}]\left[\mathrm{HSO}_{4}\right]$ and 1-butyl-3-methylimidazolium bisulfate $\left.\left[\mathrm{C}_{2} \mathrm{mim}\right]\left[\mathrm{HSO}_{4}\right]\right)$. These IL-POMs act as thermos-regulated phase transfer catalysts and decatungstate anion can react with $\mathrm{H}_{2} \mathrm{O}_{2}$ to form polyoxotungstate, which works as the active species of catalytic oxidation reaction. $[\mathrm{bPy}]_{4}\left[\mathrm{~W}_{10} \mathrm{O}_{32}\right]$ has a slightly higher selectivity for benzaldehyde than $\left[\mathrm{C}_{2} \mathrm{mim}\right]_{4}\left[\mathrm{~W}_{10} \mathrm{O}_{32}\right]$ (97.8\% and $92.7 \%$ respectively) for a similar conversion of $66 \%$ of benzylic alcohol at $80{ }^{\circ} \mathrm{C}$ after $8 \mathrm{~h}$. The conversion and selectivity for alicyclic and benzylic alcohol is comparatively higher than that of aliphatic alcohol. For aliphatic alcohol, the primary alcohols with long chain are the most difficult to oxidize. They can be converted into aldehyde with the conversion of $38.2 \%$ and the selectivity of $78.3 \%$. Under the same conditions secondary alcohols are easier to be oxidized and the conversion rises up to $88 \%$.

For benzyl alcohol oxidation L. Jing et al. ${ }^{[127]}$ studied a series of amphiphilic POM catalysts based on $\left[\mathrm{PMo}_{11} \mathrm{VO}_{40}\right]^{4-}$ and alkylammonium with different alkyl chain lengths. As the length of the alkyl chain increases, the decomposition reaction of $\mathrm{H}_{2} \mathrm{O}_{2}$ decreases, the encapsulation of the benzyl alcohol increases but the interaction between POM and $\mathrm{H}_{2} \mathrm{O}_{2}$ to form active peroxo-species decreases. Therefore, a compromise leads to the best activity for $\left(\left(n-\mathrm{C}_{8} \mathrm{H}_{17}\right)_{2}\left(\mathrm{CH}_{3}\right)_{2} \mathrm{~N}\right)_{4}\left[\mathrm{PMo}_{11} \mathrm{VO}_{40}\right]$, with $60.6 \%$ conversion of benzyl alcohol to benzaldehyde at $99 \%$ selectivity after $6 \mathrm{~h}$ at $90{ }^{\circ} \mathrm{C}$ with excellent recyclability after centrifugation.

We can also report a recent interesting work of Hao et al. ${ }^{[128]}$ They modified the phase transfer capacity of the organic cation by incorporation of polyethylene glycol (PEG) chain in diimidazolium cation in order to adjust the amphiphilic character of the catalyst between organic phase of the substrate and aqueous solution containing $\mathrm{H}_{2} \mathrm{O}_{2}$. These catalysts called PIPA-n ( $\mathrm{n}=0,4,8,13)$ (see Figure 14) are composed of polyethylene glycol (PEG)-bridged diimidazolium cations (with $0,4,8$ or $13 \mathrm{PEG}$ units) associated with $\left[\mathrm{PW}_{12} \mathrm{O}_{40}\right]^{3-}$.

The resulting crystalline solids were fully characterized and the wettability was estimated by water contact angle characterization (WCA). The WCA value of PIPA-n $(n=4,8,13)$ increased with the length of the polyether chain (see Figure 14). The catalyst was tested for alcohol oxidation with hydrogen peroxide in 1.5 molar ratio. The authors reported "an inverse dissolution-precipitation in water upon treatment with $\mathrm{H}_{2} \mathrm{O}_{2}$, which allowed for homogeneous catalysis coupled with heterogeneous separation in the $\mathrm{H}_{2} \mathrm{O}_{2}$-based aqueous oxidation system". Indeed, they demonstrated by ${ }^{31} \mathrm{P}$ NMR that the effective catalyst formed during the reaction is a peroxo-bridged species $\left[\mathrm{PW}_{4} \mathrm{O}_{8}\left(\mathrm{O}_{2}\right)_{8}\right]^{3-}$ which forms a soluble compound. With the consumption of $\mathrm{H}_{2} \mathrm{O}_{2}$, Keggin-type $\left[\mathrm{PW}_{12} \mathrm{O}_{40}\right]^{3-}$ species reformed insoluble salts. The 
catalysts recovered by centrifugation are perfectly reused for seven times without any modification of their reactivity, IR spectrum and X-Ray diffraction pattern. Therefore, PIPA salts are precursor of active peroxotungstate-ILs with phase transfer properties that can be adjusted by the number of PEG incorporated. Indeed, for benzyl alcohol, benzaldehyde was obtained with $79-86 \%$ of selectivity and a conversion of $71-96 \%$ from PIPA-0 to PIPA-13 (Table 3). A remarkable enhancement of reaction rates with the employment of PIPA-13 was also observed in the case of 1-phenylethanol, cyclohexanol, diphenylmethanol, but for nhexanol or 2-phenylethanol the conversion is less than $17 \%$.
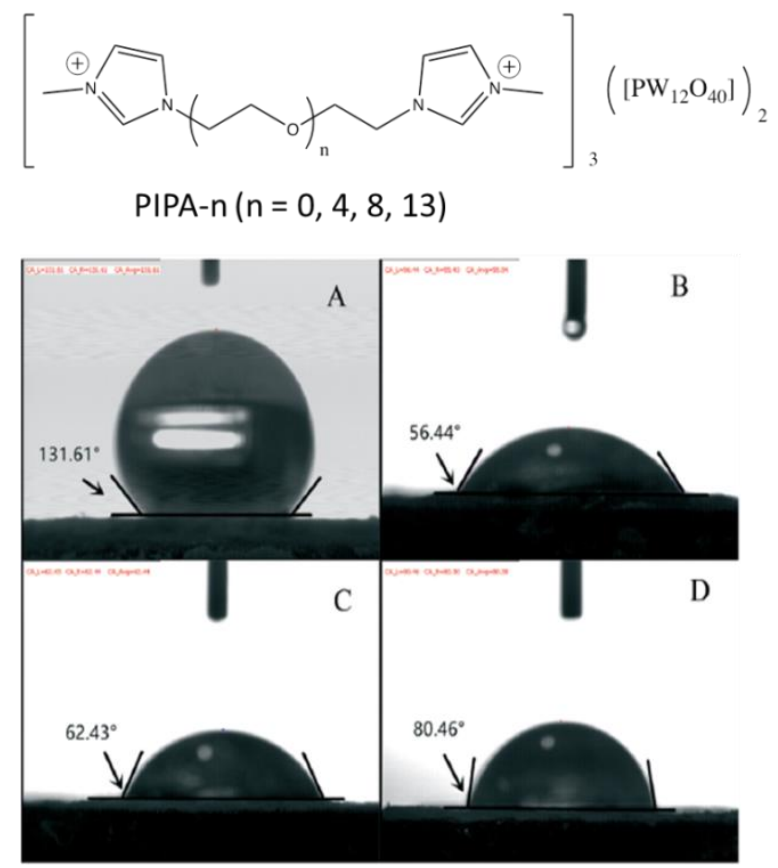

Figure 14. Drawing of the PIPA-n dications; Contact angle measurements of PIPA-0 (A), PIPA-4 (B), PIPA-8 (C) and PIPA-13 (D). (Reprinted from Hao et al. ${ }^{[128]}$ with the permission from the Royal Society of Chemistry.)

Table 3. Results of the selective oxidation of alcohols to aldehydes with $\mathrm{H}_{2} \mathrm{O}_{2}$ in water over various catalysts. ${ }^{[128]}$

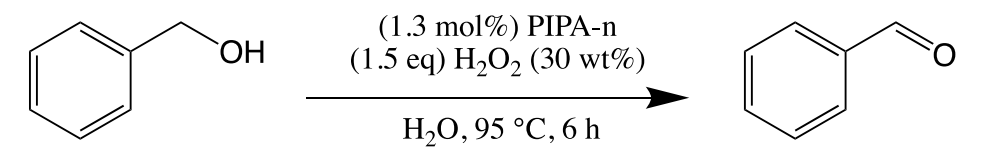

\begin{tabular}{lccc}
\hline Entry & Catalyst & ${\text { Conv. }(\%)^{\mathrm{a}}}$ & Sel. (\%) $^{\mathrm{b}}$ \\
\hline 1 & PIPA-0 & 71 & 82 \\
2 & PIPA-4 & 88 & 79 \\
3 & PIPA-8 & 91 & 84 \\
4 & PIPA-13 & 96 & 86 \\
\hline
\end{tabular}

\footnotetext{
${ }^{\mathrm{a}}$ The conversion was based on alcohols; ${ }^{\mathrm{b}}$ The selectivity was based on the corresponding aldehydes or ketones.
} 


\section{- Epoxidation of olefins}

Qiao et al. ${ }^{[105]}$ reported two protic (N-dodecylimidazolium peroxotungstate $\left[\mathrm{HC}_{12} \mathrm{im}\right]_{2}\left[\mathrm{~W}_{2} \mathrm{O}_{11}\right]$ and $\mathrm{N}$-hexylimidazolium peroxotungstate $\left.\left[\mathrm{HC}_{6} \mathrm{im}\right]_{2}\left[\mathrm{~W}_{2} \mathrm{O}_{11}\right]\right)$ and two aprotic salts (1-hexyl-3-methyl-imidazolium peroxotungstate $\left[\mathrm{C}_{6} \mathrm{mim}\right]_{2}\left[\mathrm{~W}_{2} \mathrm{O}_{11}\right]$ and 1dodecyl-3-methyl-imidazolium peroxotungstate $\left[\mathrm{C}_{12} \mathrm{mim}\right]_{2}\left[\mathrm{~W}_{2} \mathrm{O}_{11}\right]$ ) as catalysts for the epoxidation of olefins by using simple aqueous $\mathrm{H}_{2} \mathrm{O}_{2}$ as co-oxidant. After $4 \mathrm{~h}$ without solvent at $60{ }^{\circ} \mathrm{C}$, the conversion of cyclooctene in cyclooctene-oxide was obtained between 24 and $66 \%$ with a selectivity up to $99 \%$ (see Figure 15 ).

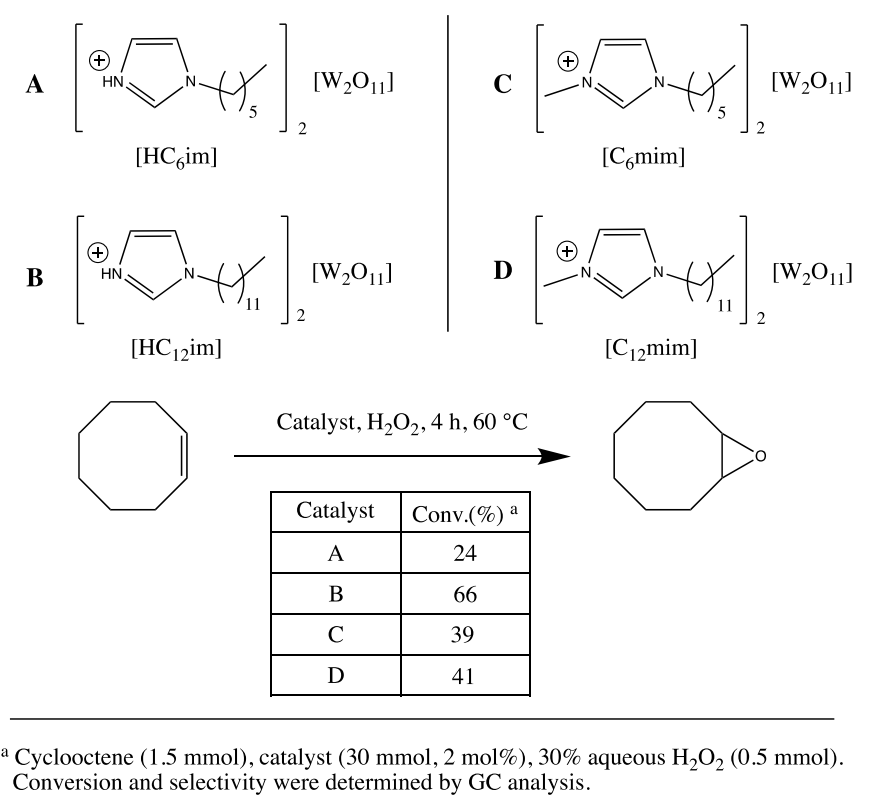

Figure 15. Representation of the salts of the peroxotungstate anion $\left[\mathrm{W}_{2} \mathrm{O}_{11}\right]^{2-}$ with their efficiency for Epoxidation of cyclooctene. From Qiao et al. ${ }^{[105]}$

The length of the alkyl chain in the imidazolium cation plays an important role in the reaction. Indeed, $\left[\mathrm{HC}_{12} \mathrm{im}\right]_{2}\left[\mathrm{~W}_{2} \mathrm{O}_{11}\right]$ was proved to be the most active catalyst among them for the epoxidation of olefins. Furthermore, this POM-IL "catalytic system switched the reaction mixture from tri-phase to emulsion, then to biphasic, and finally the catalyst self-precipitated in the reaction medium at the end of the reaction."

The catalytic system combined the advantages of a homogeneous catalyst during the reaction with a heterogeneous catalyst after the reaction. By decantation, the catalyst can be easily recycled for at least six times. This study provides an effective approach to circumvent the difficulty of separating homogeneous epoxidation catalysts from the products. 


\section{- Oxidative cleavage of olefin and alcohol oxidation into carboxylic acid:}

In 2005, a team of the G. K. Boreskov Institute of Catalysis in Russia synthetized a yellowish syrup-like substance of $\left[\left(n-\mathrm{C}_{8} \mathrm{H}_{17}\right)_{3} \mathrm{~N}\left(\mathrm{CH}_{3}\right)\right]^{+}$ammonium salt of $\left\{\mathrm{PO}_{4}\left[\mathrm{WO}\left(\mathrm{O}_{2}\right)_{2}\right]_{4}\right\}^{3-}$ and applied this one in oxidative cleavage of olefin. ${ }^{[100]}$ With 0.005 eq of POM-IL and 2 eq of $30 \mathrm{wt} \%$ aqueous $\mathrm{H}_{2} \mathrm{O}_{2}$ at $90{ }^{\circ} \mathrm{C}$, cyclohexene was cut in hexane-1,6-dioic with $72 \%$ yield (Table 4). The same publication also described that the reaction of $\left[\left(\mathrm{CH}_{3}\right)\left(n-\mathrm{C}_{8} \mathrm{H}_{17}\right)_{3} \mathrm{~N}\right]_{3}\left\{\mathrm{PO}_{4}\left[\mathrm{WO}\left(\mathrm{O}_{2}\right)_{2}\right]_{4}\right\}$ and primary alcohols in the same conditions lead to the corresponding carboxylic acids with good yields (Table 4). The results of this publication prove the strong oxidative character of POMs when the conditions are optimized and when cations are chosen in order to produce real POM-ILs.

Table 4. Catalytic oxidation of olefinic compounds or alcohols with hydrogen peroxide ${ }^{\text {a }}{ }^{100]}$

Entry Substrates Pield (\%)

${ }^{a}$ Catalyst (0.005 eq), substrates (1 eq), $\mathrm{H}_{2} \mathrm{O}_{2}(30 \mathrm{wt} \%, 2 \mathrm{eq}), 90{ }^{\circ} \mathrm{C}, 3 \mathrm{~h}$.

\section{- Desulfurization}

Nowadays, hydrodesulfurization (HDS) method remains an important challenge in fuel industry. Zhu et al. ${ }^{[104]}$ proposed a biphasic system with hydrogen peroxide and $N$-methyl- $N$ trialkylammoniums of $\left\{\mathrm{PO}_{4}\left[\mathrm{MO}\left(\mathrm{O}_{2}\right)_{2}\right]_{4}\right\} \quad(\mathrm{M}=\mathrm{Mo}$ or $\mathrm{W})$ as catalyst for a model oil desulfurization. In this model oil, DBT (dibenzothiophene) was selected as it was one of the main refractory sulfur-containing compounds in the HDS treatment. The results given in Table 5 proved the complete sulfur removal of the system by using four highly viscous POMILs. 
Table 5. Sulfur removal of different desulfurization systems ${ }^{\text {a }}{ }^{[104]}$

\begin{tabular}{|c|c|c|}
\hline Entry & POM-IL & Sulfur removal (\%) \\
\hline 1 & {$\left[\left(\mathrm{n}-\mathrm{C}_{8} \mathrm{H}_{17}\right)_{3} \mathrm{NCH}_{3}\right]_{3}\left\{\mathrm{PO}_{4}\left[\mathrm{MoO}\left(\mathrm{O}_{2}\right)_{2}\right]_{4}\right\}$} & 100 \\
\hline 2 & {$\left[\left(\mathrm{n}-\mathrm{C}_{12} \mathrm{H}_{25}\right)_{3} \mathrm{NCH}_{3}\right]_{3}\left\{\mathrm{PO}_{4}\left[\mathrm{MoO}\left(\mathrm{O}_{2}\right)_{2}\right]_{4}\right\}$} & 100 \\
\hline 3 & {$\left[\left(\mathrm{n}-\mathrm{C}_{8} \mathrm{H}_{17}\right)_{3} \mathrm{NCH}_{3}\right]_{3}\left\{\mathrm{PO}_{4}\left[\mathrm{WO}\left(\mathrm{O}_{2}\right)_{2}\right]_{4}\right\}$} & 100 \\
\hline 4 & {$\left[\left(\mathrm{n}-\mathrm{C}_{12} \mathrm{H}_{25}\right)_{3} \mathrm{NCH}_{3}\right]_{3}\left\{\mathrm{PO}_{4}\left[\mathrm{WO}\left(\mathrm{O}_{2}\right)_{2}\right]_{4}\right\}$} & 100 \\
\hline
\end{tabular}

\section{- Photoreaction}

A new POM-IL photocatalyst was described by Dong et al. in 2011. ${ }^{[107]}$ In this contribution, photocatalytic performances of the POM-IL were measured via degrading the dye Rhodamine B (RB) in aqueous solution under the UV light irradiation. The POM-IL studied was an association of two alkyl-imidazolium cations and a molybdo-lindqvist polyoxometalate: $\left[\mathrm{C}_{8} \mathrm{mim}\right]_{2}\left[\mathrm{Mo}_{6} \mathrm{O}_{19}\right]$. With a melting point at $82.6{ }^{\circ} \mathrm{C}$, this real POM-IL showed good photocatalytic activity for degrading RB with a conversion of $80.5 \%$ under UV-light for 90 min. The same group studied two other POM-ILs based on octamolybdate $\left[\mathrm{C}_{\mathrm{n}} \mathrm{mim}\right]_{4}\left[\mathrm{Mo}_{8} \mathrm{O}_{26}\right]$ $(n=12,14)$ with low melting points. ${ }^{[108]}$ The results for photocatalytic degradation of RB are reported in Table 6 . After three catalytic runs, the performance was stable.

Table 6. Degradation rate of Rhodamine B (RB) (\%) after three catalytic runs ${ }^{\text {[ }}{ }^{108]}$

\begin{tabular}{clll}
\hline Catalyst & $1^{\text {st }}$ & $2^{\text {ed }}$ & $3^{\text {th }}$ \\
\hline$\left[\mathrm{C}_{12} \mathrm{mim}\right]_{4}\left[\mathrm{Mo}_{8} \mathrm{O}_{26}\right]$ & 77 & 76 & 75 \\
{$\left[\mathrm{C}_{14} \mathrm{mim}\right]_{4}\left[\mathrm{Mo}_{8} \mathrm{O}_{26}\right]$} & 80 & 78 & 77 \\
\hline $\mathrm{a}$ & $80 \mathrm{H}=1,10 \mathrm{mg}$ &
\end{tabular}

${ }^{\mathrm{a}} \mathrm{pH}=1,10 \mathrm{mg} / \mathrm{L} \mathrm{RB}, 0.2 \mathrm{~g} / \mathrm{L}$ catalyst, under UV-light for $90 \mathrm{~min}$.

\section{- Other organic reactions (acidic reaction):}

The full charge compensation of POM by cation of IL is expected to prevent the Brönsted acidic property, therefore mixed acid salts has been prepared and used for acidic reactions.

\section{Esterification}

Li et al., proposed a catalyst prepared by partial exchange of the protons of the $\left[\mathrm{H}_{3} \mathrm{PW}_{12} \mathrm{O}_{40}\right]$ by a PEG-2000 chain-functionalized alkylimidazolium chloride (see Figure 2 for representation of the cation). ${ }^{[106]}$ The POM-ILs synthetized with $\mathrm{n}=39-48$ presented a liquid state at room temperature and its viscosity was equal to 9.9 Pa.s at $30{ }^{\circ} \mathrm{C}$. Biphasic 
esterification of acetic acid with different alcohols were performed with good esterification yields. Table 7 shows that the POM-IL catalyst maintained the excellent catalytic performances of its parent heteropolyacid. Moreover, emulsion caused during the reaction was believed to be stabilized by the amphiphilic characteristic of the POM-IL catalyst. This one facilitated not only the catalytic reaction but also the separation of products and can be reused for 8 times (Table 7 , entry 3 ).

Table 7. The esterification of different alcohols with acetic acid ${ }^{\mathrm{a}}{ }^{[106]}$

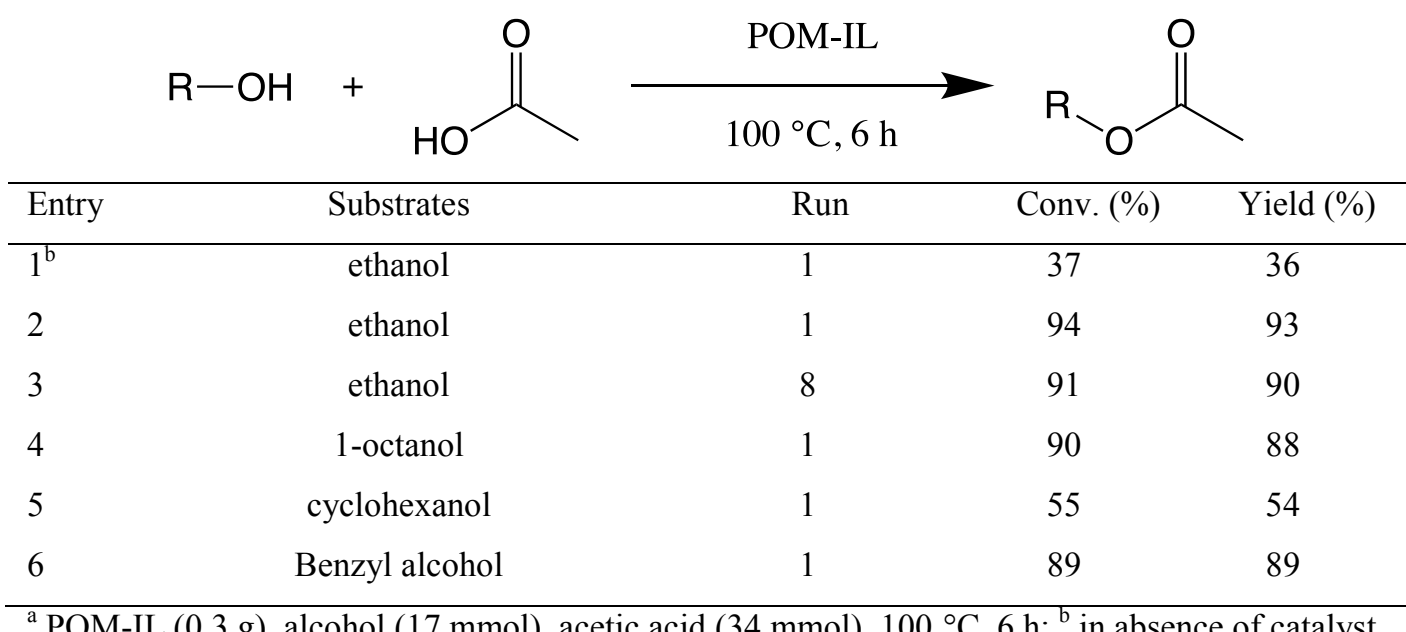

\section{Oxidative esterification of aldehyde}

In the same paper $\mathrm{Li}$ et al, studied the reactivity of this POM-IL for the oxidative esterification of benzaldehyde and various other aldehydes with methanol. ${ }^{[106]}$

At optimum conditions, a methyl benzoate yield of 70\% was achieved after $8 \mathrm{~h}$ (Table 8 , entry 1). The amount of methanol and $\mathrm{H}_{2} \mathrm{O}_{2}(30 \mathrm{wt} \%)$ drastically affected the yield of methyl benzoate. When more methanol was used, the ester yield decreased in the benefit of aldehyde acetal. With an excess of $\mathrm{H}_{2} \mathrm{O}_{2}$, the main product was benzoic acid and the yield of the ester was also decreased. Saturated aldehydes, such as cyclohexanal, could also be converted to the corresponding ester with a high yield (77\%; Table 8 , entry 5$)$, while pivalaldehyde presented a lower yield (45\%; entry 6$)$. 
Table 8. Oxidative esterification of aldehydes with methanol ${ }^{\mathrm{a}}{ }^{[106]}$

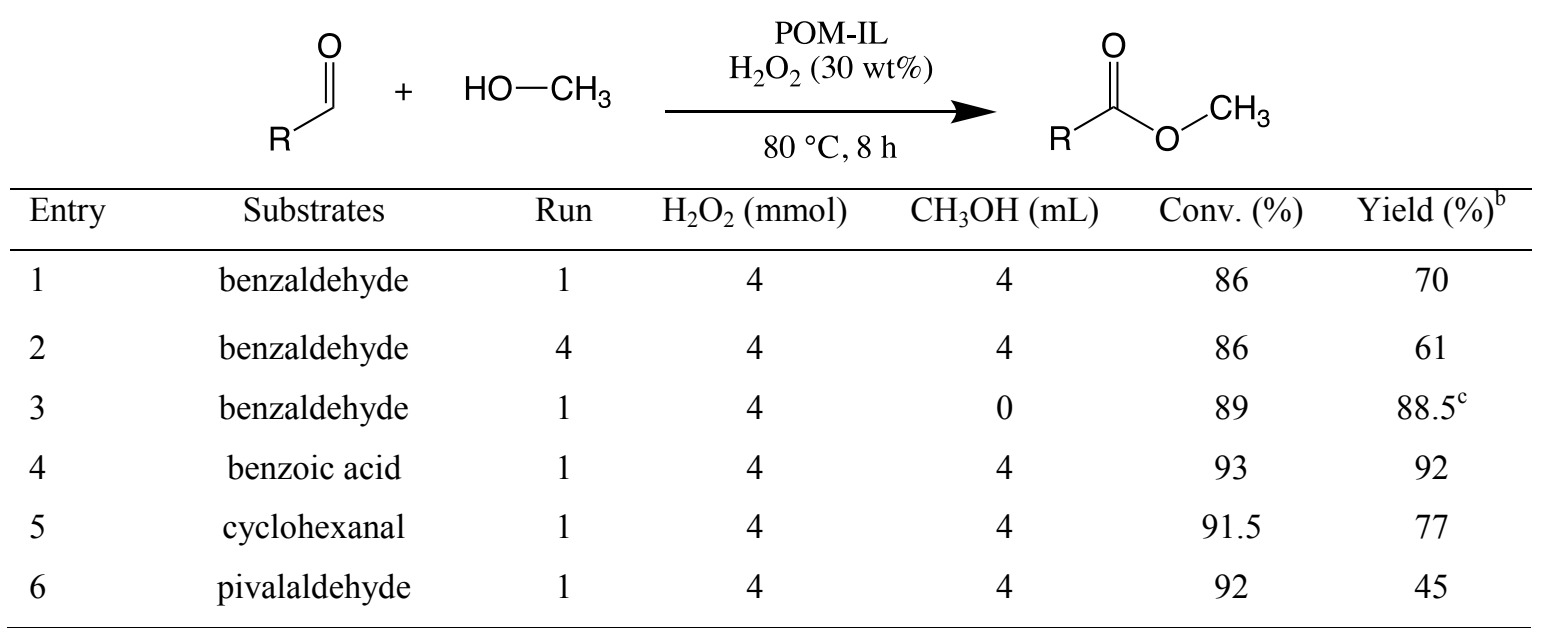

${ }^{\mathrm{a}} 30 \mathrm{wt} \% \mathrm{H}_{2} \mathrm{O}_{2}$, IL $(0.1 \mathrm{~g})$, aldehyde $(1 \mathrm{mmol}), 8 \mathrm{~h}, 80^{\circ} \mathrm{C} ;{ }^{\mathrm{b}}$ unless otherwise stated, yields of the corresponding methyl esters; ${ }^{c}$ yield of benzoic acid.

Stability of the catalyst was studied for recyclability purposes by IR and ${ }^{31} \mathrm{P}$ NMR spectroscopies. In this reaction, the catalyst was first degraded to several peroxo species that were responsible of the oxidation of benzaldehyde, and after the $\mathrm{H}_{2} \mathrm{O}_{2}$ was used up, they were mainly transformed back into the Keggin structure. However, a small proportion of the catalyst remained degraded into peroxo species, limiting the recyclability.

\section{2-2-2 Other Applications}

Not only concerned by application in catalysis, some groups, especially the teams of Streb in Germany and Mitchell in Spain opened new avenues towards unexpected exciting practical applications of POM-ILs. By using $\left[\mathrm{SiW}_{11} \mathrm{O}_{39} \mathrm{Cu}\left(\mathrm{H}_{2} \mathrm{O}\right)\right]^{6-}$ or $\left[\mathrm{SiW}_{11} \mathrm{O}_{39} \mathrm{Fe}\left(\mathrm{H}_{2} \mathrm{O}\right)\right]^{5-}$ paired with tetraalkylammonium cations $\left(\left(n-\mathrm{C}_{6} \mathrm{H}_{13}\right)_{4} \mathrm{~N}^{+}\right)$or $\left(\left(n-\mathrm{C}_{7} \mathrm{H}_{15}\right)_{4} \mathrm{~N}^{+}\right)$, Streb and his coworkers discovered in 2014 that the corrosion resistance against acetic acid vapors of copper metal disks is significantly improved when using these room-temperature POM-ILs as coatings compared to commercial ionic liquids or solid polyoxometalate coatings (see Figure 16). Furthermore, due to the viscosity of POM-IL, after mechanical damage, the POM-IL coating repairs itself in less than one minute with full retention of the acid protection properties. Finally, the coating can easily be removed and recovered by rinsing with organic solvents, thus offering recyclability properties for such POM-IL-based treatment. ${ }^{[118]}$ 


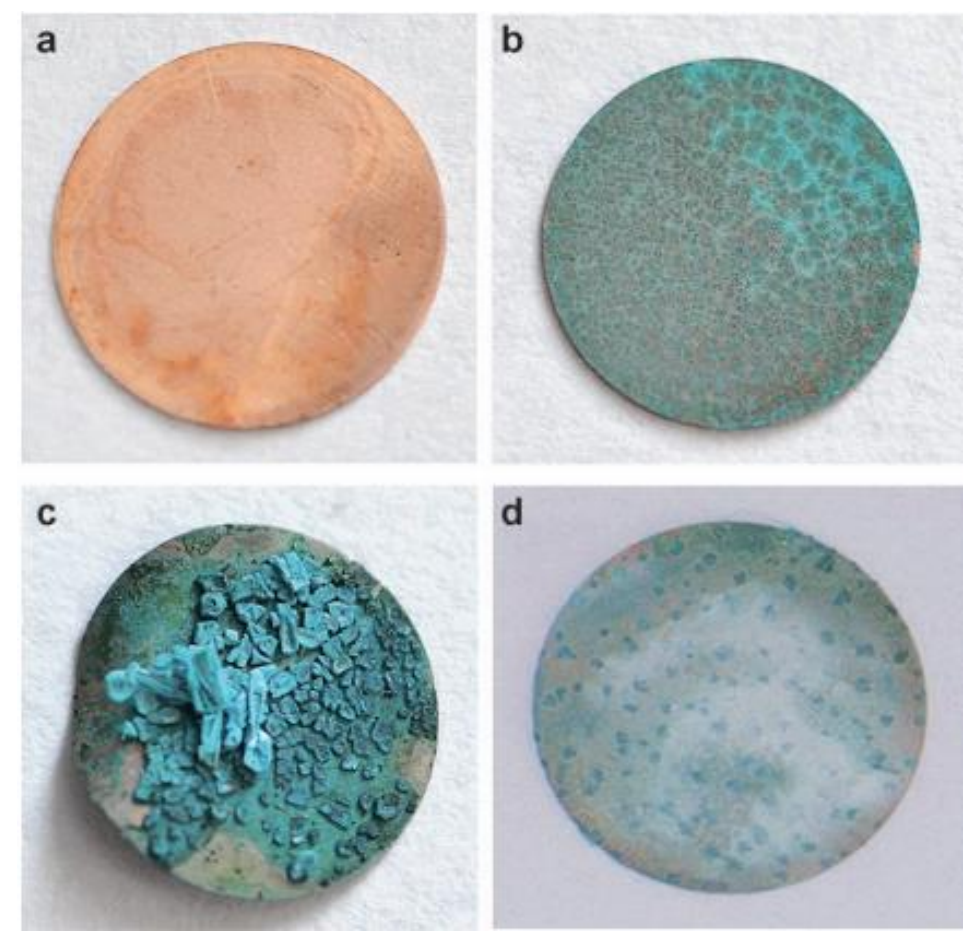

Figure 16. Cu disks $(\mathrm{d}=1 \mathrm{~cm})$ exposed to aqueous acetic acid $(50 \%)$ vapor for $24 \mathrm{~h}$. a) coating: ((n$\left.\left.\mathrm{C}_{8} \mathrm{H}_{17}\right)_{4} \mathrm{~N}^{+}\right)_{6}\left[\alpha-\mathrm{SiW}_{11} \mathrm{O}_{39} \mathrm{Cu}\left(\mathrm{H}_{2} \mathrm{O}\right)\right]$; b) non-coated $\mathrm{Cu}$ disk; c) coating: commercial IL [ $\left.\mathrm{C}_{6} \mathrm{mim}\right] \mathrm{Br}$; d) coating: solid compound $\left(\left(n-\mathrm{C}_{5} \mathrm{H}_{11}\right)_{4} \mathrm{~N}^{+}\right)_{6}\left[\alpha-\mathrm{SiW}_{11} \mathrm{O}_{39} \mathrm{Cu}\left(\mathrm{H}_{2} \mathrm{O}\right)\right]$. (Reprinted from Streb et al. ${ }^{[118]}$ with the permission from Wiley.)

Not only anticorrosive for metals, the same POM-ILs revealed to be useful for the protection of historical heritage, for depollution and for antibacterial activity. In 2017, Streb, Mitchell et $a l$. focused their attention on the antimicrobial activity of POM-ILs against clinically relevant pathogens. ${ }^{[120,121]}$ These studies revealed that the lacunary POM $\left[\mathrm{SiW}_{11} \mathrm{O}_{39}\right]^{8-}$ paired with tetra-hexyl, -heptyl and -octyl-ammonium cations exhibits a high activity against E. coli, $P$. aeruginosa, and particularly against $S$. aureus. Moreover, the variation of the tetraalkylammonium cations chain length modified the antimicrobial activity indicating the non-innocent role of the cations for such a property, longer chains resulting in higher activity. In comparison, the same year, $\mathrm{Hu}$ et al. ${ }^{[129]}$ tested the efficiency of $\left(\left(\mathrm{MePh}_{3} \mathrm{P}\right)_{3}\left[\mathrm{PMo}_{12} \mathrm{O}_{40} \cdot \mathrm{nH}_{2} \mathrm{O}\right]\right)$ on bacteria. The results indicated that the amount of water present in the IL-POMs $\left(\left(\mathrm{MePh}_{3} \mathrm{P}\right)_{3}\left[\mathrm{PMo}_{12} \mathrm{O}_{40} \cdot \mathrm{nH}_{2} \mathrm{O}\right]\right)$ played also a key role in the morphology of compounds and the compounds showed good antibacterial activities against $E$. coli and S. aureus, which resulted from the increase of the positive electrical charge of quaternary phosphonium cation by the polarization between the POMs and phosphonium cation. 
In the following of these studies Mitchell and Streb used the previous POM-ILs ( $n$ $\left.\left.\mathrm{C}_{7} \mathrm{H}_{15}\right)_{4} \mathrm{~N}^{+}\right)_{8}\left[\alpha-\mathrm{SiW}_{11} \mathrm{O}_{39}\right]$ and $\left(\left(n-\mathrm{C}_{6} \mathrm{H}_{13}\right)_{3}\left(n-\mathrm{C}_{14} \mathrm{H}_{29}\right) \mathrm{N}^{+}\right)_{8}\left[\alpha-\mathrm{SiW}_{11} \mathrm{O}_{39}\right]$ to efficiently protect different types of natural stones against corrosive acid rains by formation of POM-IL based anticorrosion and antibacterial transparent coatings (Figure 17). They demonstrated that the treatment of stones by such POM-ILs, gives good surface-adherence and water-repellency thus forming an acid-stable, biocidal surface layer. Moreover, POM-ILs are not removed even by harsh mechanical and chemical treatment, proving if needed, that POM-ILs can efficiently participate to the protection of our historical heritage.

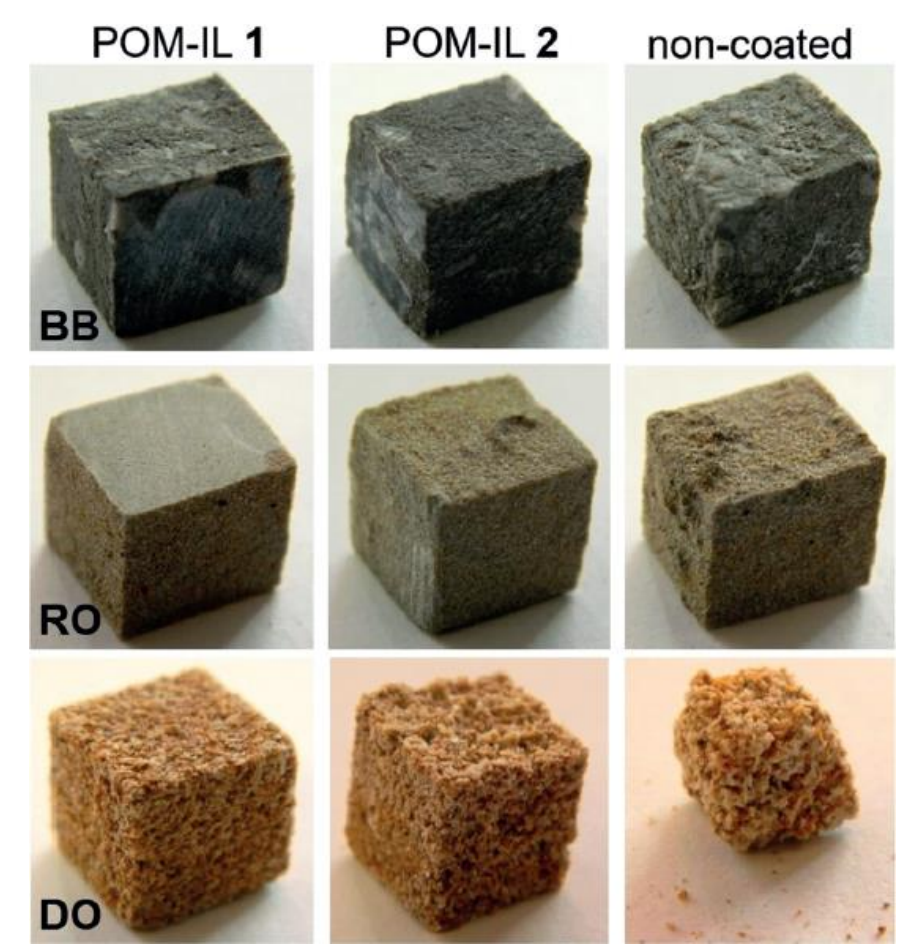

Figure 17: Acid-rain corrosion protection of POM-IL coated stone samples. POM-IL $1=((n-$ $\left.\left.\mathrm{C}_{7} \mathrm{H}_{15}\right)_{4} \mathrm{~N}\right)_{8}\left[\mathrm{SiW}_{11} \mathrm{O}_{39}\right]$ and POM-IL $2=\left(\left(\mathrm{n}-\mathrm{C}_{6} \mathrm{H}_{13}\right)_{3}\left(\mathrm{C}_{14} \mathrm{H}_{29}\right) \mathrm{N}\right)_{8}\left[\mathrm{SiW}_{11} \mathrm{O}_{39}\right]$. RO: Romery stone; BB: Belgian Bluestone; DO: Dom stone. (Reprinted from Mitchell, Streb et al. ${ }^{[122]}$ with the permission from Wiley.)

Finally, by supporting $\left(\left(\mathrm{n}-\mathrm{C}_{7} \mathrm{H}_{15}\right)_{4} \mathrm{~N}\right)_{8}\left[\mathrm{SiW}_{11} \mathrm{O}_{39}\right]$ on porous silica, the resulting functionalized silica revealed to be a multifunctional material capable of removing efficiently heavy metal contaminants in water by coordination to the lacunary POM but also organic pollutants (e.g., dyes) and microbes (E. coli, P. aeruginosa, S. aureus) (Figure 18). These results prompt other authors to use POM-ILs for water treatment such as Shakeela and Rao ${ }^{[124]}$ who suggested to use the excellent hydrophobic solvents properties of tetra-n-octylammonium salts of $\left[\mathrm{PW}_{11} \mathrm{MO}_{39}\right]^{\mathrm{n}-}(\mathrm{M}=\mathrm{Mn}, \mathrm{Fe}, \mathrm{Co}, \mathrm{Ni}, \mathrm{Cu}$, and $\mathrm{Zn})$ for the removal of $\mathrm{Cd}^{2+}$ and $\mathrm{Pb}^{2+}$ metal ions from aqueous solutions. 


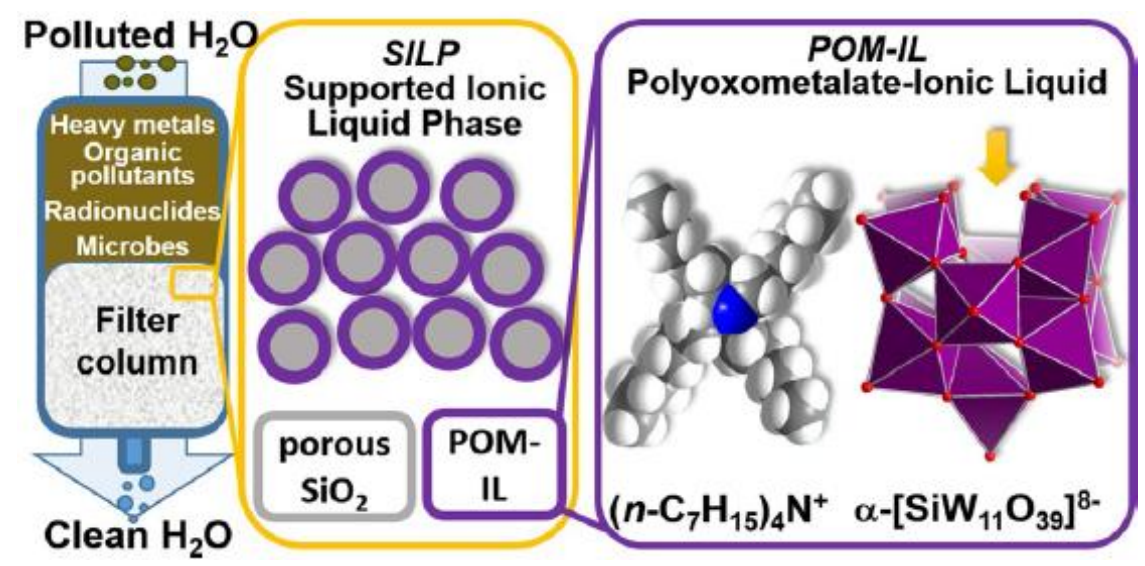

Figure 18: Water purification using polyoxometalate supported ionic liquid phases (POM-SILPs) based on lipophilic POM-ILs supported on porous silica. (Reprinted from Mitchell, Streb et al. ${ }^{[122]}$ with the permission from Wiley.)

\section{Conclusion}

As a conclusion, the objective of this mini-review was to highlight how we can design POMbased Liquid Crystals or Ionic Liquids with an accurate choice of the POM and more importantly the organic cation. By playing on both components plethora of compounds have been obtained during the last 15 years and these domains of investigation are still young. In our opinion, even if the study of POM-based liquid crystals remains mainly of fundamental interest it can easily evolve towards optoelectronic devices. On their side, POM-ILs offer a large panel of applications through the combination of the properties of POMs and counter cations but also thanks to the rheological properties of ILs phases. Catalysis probably remains the main field of development for today's and tomorrow's challenges. In particular, POM-ILs can participate to the valorization of biomass, and some authors like De Gregorio et al. explored a new way for the oxidative depolymerization of lignin by using $\mathrm{H}_{5}\left[\mathrm{PMo}_{10} \mathrm{~V}_{2} \mathrm{O}_{40}\right]$ solubilized in the IL $\left[\mathrm{HC}_{4} \mathrm{im}\right]\left[\mathrm{HSO}_{4}\right]$. In contact with lignin and in the presence of molecular oxygen or hydrogen peroxide they succeeded to produce vanillin and syringaldehyde with no indication of over-oxidation into carboxylic acids. ${ }^{[130]}$ Besides, Rogers' team published two papers on the dissolution and delignification of woody biomass by using of POM@IL and ILPOM@IL with or without oxygen, ${ }^{[131,132]}$ while imidazolium based ILs have been proven to be efficient catalyst for C-O bond cleavage of lignin. ${ }^{[133]}$ These examples pave the way towards the use of POM-ILs to develop sustainable processes of valorization of biomass for the production of biosourced valuable molecules. On another hand, some avenues towards 
new practical applications in unexpected domains have been opened in the last five years by several authors worldwide. Taken into account the relatively easy high scale synthesis of POMs and therefore the resulting POM-ILs, these allow envisioning fantastic developments to tackle new challenges in the future.

\section{Acknowledgements}

Authors would like to thank Ms. S. Basset, Mr. M. Duguet and Mr. A. Fuior for their help during the preparation of the manuscript. This work is supported by a public grant overseen by the French National research Agency (ANR) as part of the «Investissement d'Avenir » program, through the "IDI 2017" project funded by the IDEX Paris-Saclay, ANR-11-IDEX0003-02. INRA, CNRS, University of Versailles and Institut Universitaire de France are also gratefully acknowledged for their financial support. 


\section{References}

[1] C. G. Lin, G. D. Fura, Y. Long, W. M. Xuan, Y. F. Song, Inorg. Chem. Front. 2017, 4, 789-794.

[2] G. Izzet, B. Abecassis, D. Brouri, M. Piot, B. Matt, S. A. Serapian, C. Bo, A. Proust, J. Am. Chem. Soc. 2016, 138, 5093-5099.

[3] Y. Zhu, P. C. Yin, F. P. Xiao, D. Li, E. Bitterlich, Z. C. Xiao, J. Zhang, J. Hao, T. B. Liu, Y. Wang, Y. G. Wei, J. Am. Chem. Soc. 2013, 135, 17155-17160.

[4] J. Marrot, M. A. Pilette, M. Haouas, S. Floquet, F. Taulelle, X. Lopez, J. M. Poblet, E. Cadot, J. Am. Chem. Soc. 2012, 134, 1724-1737.

[5] M. D. Symes, P. J. Kitson, J. Yan, C. J. Richmond, G. J. T. Cooper, R. W. Bowman, T. Vilbrandt, L. Cronin, Nat. Chem. 2012, 4, 349-354.

[6] D. L. Long, R. Tsunashima, L. Cronin, Angew. Chem.-Int. Edit. 2010, 49, 1736-1758.

[7] T. Yamase, J. Mater. Chem. 2005, 15, 4773-4782.

[8] A. Bijelic, M. Aureliano, A. Rompel, Angew. Chem.-Int. Edit. 2019, 58, 2980-2999.

[9] A. Bijelic, M. Aureliano, A. Rompel, Chem. Commun. 2018, 54, 1153-1169.

[10] W. Salomon, Y. H. Lan, E. Riviere, S. Yang, C. Roch-Marchal, A. Dolbecq, C. Simonnet-Jegat, N. Steunou, N. Leclerc-Laronze, L. Ruhlmann, T. Mallah, W. Wernsdorfer, P. Mialane, Chem.-Eur. J. 2016, 22, 6564-6574.

[11] G. Charron, A. Giusti, S. Mazerat, P. Mialane, A. Gloter, F. Miserque, B. Keita, L. Nadjo, A. Filoramo, E. Riviere, W. Wernsdorfer, V. Huc, J. P. Bourgoin, T. Mallah, Nanoscale 2010, 2, 139-144.

[12] J. M. Clemente-Juan, E. Coronado, A. Gaita-Arino, Chem. Soc. Rev. 2012, 41, 7464-7478.

[13] J. W. Vickers, H. J. Lv, J. M. Sumliner, G. B. Zhu, Z. Luo, D. G. Musaev, Y. V. Geletii, C. L. Hill, J. Am. Chem. Soc. 2013, 135, 14110-14118.

[14] B. B. Sarma, R. Neumann, Nat. Commun. 2014, 5, 4621

[15] M. Natali, M. Orlandi, S. Berardi, S. Campagna, M. Bonchio, A. Sartorel, F. Scandola, Inorg. Chem. 2012, 51, 7324-7331.

[16] B. Keita, L. Nadjo, J. Mol. Catal. A-Chem. 2007, 262, 190-215.

[17] C. Freire, D. M. Fernandes, M. Nunes, V. K. Abdelkader, ChemCatChem 2018, 10, 1703-1730.

[18] R. J. Liu, G. J. Zhang, H. B. Cao, S. J. Zhang, Y. B. Xie, A. Haider, U. Kortz, B. H. Chen, N. S. Dalal, Y. S. Zhao, L. J. Zhi, C. X. Wu, L. K. Yan, Z. M. Su, B. Keita, Energy Environ. Sci. 2016, 9, 10121023.

[19] N. V. Izarova, M. T. Pope, U. Kortz, Angew. Chem.-Int. Edit. 2012, 51, 9492-9510.

[20] H. N. Miras, J. Yan, D. L. Long, L. Cronin, Chem. Soc. Rev. 2012, 41, 7403-7430.

[21] A. Müller, P. Gouzerh, Chem. Soc. Rev. 2012, 41, 7431-7463.

[22] M. Nyman, P. C. Burns, Chem. Soc. Rev. 2012, 41, 7354-7367.

[23] O. Oms, A. Dolbecq, P. Mialane, Chem. Soc. Rev. 2012, 41, 7497-7536.

[24] A. Proust, B. Matt, R. Villanneau, G. Guillemot, P. Gouzerh, G. Izzet, Chem. Soc. Rev. 2012, 41, 7605-7622.

[25] S. T. Zheng, G. Y. Yang, Chem. Soc. Rev. 2012, 41, 7623-7646.

[26] A. Lombana, C. Rinfray, F. Volatron, G. Izzet, N. Battaglini, S. Alves, P. Decorse, P. Lang, A. Proust, J. Phys. Chem. C 2016, 120, 2837-2845.

[27] S. G. Derouich, C. Rinfray, G. Izzet, J. Pinson, J. J. Gallet, F. Kanoufi, A. Proust, C. Combellas, Langmuir 2014, 30, 2287-2296.

[28] G. Izzet, F. Volatron, A. Proust, Chem. Rec. 2017, 17, 250-266.

[29] A. Dolbecq, E. Dumas, C. R. Mayer, P. Mialane, Chem. Rev. 2010, 110, 6009-6048.

[30] A. Müller, E. Krickemeyer, H. Bögge, M. Schmidtmann, F. Peters, Angew. Chem.-Int. Edit. 1998, 37, 3360-3363.

[31] A. Müller, P. Gouzerh, Chem.-Eur. J. 2014, 20, 4862-4873.

[32] T.-L. Lai, M. Awada, S. Floquet, C. Roch-Marchal, N. Watfa, J. Marrot, M. Haouas, F. Taulelle, E. Cadot, Chem.-Eur. J. 2015, 21, 13311-13320. 
[33] V. S. Korenev, A. G. Boulay, M. Haouas, F. Bannani, V. P. Fedin, M. N. Sokolov, E. Terazzi, S. Garai, A. Müller, F. Taulelle, J. Marrot, N. Leclerc, S. Floquet, E. Cadot, Chem.-Eur. J. 2014, 20, 3097-3105.

[34] A. Merca, E. T. K. Haupt, T. Mitra, H. Bögge, D. Rehder, A. Müller, Chem.-Eur. J. 2007, 13, 7650-7658.

[35] A. Müller, Y. S. Zhou, L. J. Zhang, H. Bögge, M. Schmidtmann, M. Dressel, J. van Slageren, Chem. Commun. 2004, 2038-2039.

[36] A. Müller, D. Rehder, E. T. K. Haupt, A. Merca, H. Bögge, M. Schmidtmann, G. HeinzeBruckner, Angew. Chem.-Int. Edit. 2004, 43, 4466-4470.

[37] A. Müller, S. K. Das, S. Talismanov, S. Roy, E. Beckmann, H. Bögge, M. Schmidtmann, A. Merca, A. Berkle, L. Allouche, Y. S. Zhou, L. J. Zhang, Angew. Chem.-Int. Edit. 2003, 42, 50395044.

[38] S. Kopilevich, A. Gil, M. Garcia-Rates, J. Bonet-Avalos, C. Bo, A. Müller, I. A. Weinstock, J. Am. Chem. Soc. 2012, 134, 13082-13088.

[39] C. Besson, S. Schmitz, K. M. Capella, S. Kopilevich, I. A. Weinstock, P. Kögerler, Dalton Trans. 2012, 41, 9852-9854.

[40] A. Misra, K. Kozma, C. Streb, M. Nyman, Angew. Chem.-Int. Edit. 2019, ASAP.

[41] D. G. Kurth, P. Lehmann, D. Volkmer, A. Müller, D. Schwahn, J. Chem. Soc.-Dalton Trans. 2000, 3989-3998.

[42] D. Volkmer, A. Du Chesne, D. G. Kurth, H. Schnablegger, P. Lehmann, M. J. Koop, A. Müller, J. Am. Chem. Soc. 2000, 122, 1995-1998.

[43] Y. Y. Bao, L. H. Bi, L. X. Wu, S. S. Mal, U. Kortz, Langmuir 2009, 25, 13000-13006.

[44] N. Anwar, M. Vagin, R. Naseer, S. Imar, M. Ibrahim, S. S. Mal, U. Kortz, F. Laffir, T. McCormac, Langmuir 2012, 28, 5480-5488.

[45] S. Noro, R. Tsunashima, Y. Kamiya, K. Uemura, H. Kita, L. Cronin, T. Akutagawa, T. Nakamura, Angew. Chem.-Int. Edit. 2009, 48, 8703-8706.

[46] H. Li, Y. Yang, Y. Wang, C. Wang, W. Li, L. Wu, Soft Matter 2011, 7, 2668-2673.

[47] A. Cazacu, S. Mihai, G. Nasr, E. Mahon, A. van der Lee, A. Meffre, M. Barboiu, Inorganica Chimica Acta 363 (2010) 4214-4219 2010, 363, 4214-4219.

[48] B. Li, W. Li, H. Li, L. Wu, Accounts Chem. Res. 2017, 50, 1391-1399.

[49] E. Terazzi, G. Rogez, J. L. Gallani, B. Donnio, J. Am. Chem. Soc. 2013, 135, 2708-2722.

[50] K. Binnemans, C. Gorller-Walrand, Chem. Rev. 2002, 102, 2303-2345.

[51] W. Li, L. Wu, Polym. Int. 2014, 63, 1750-1764.

[52] N. Tirelli, F. Cardullo, T. Habicher, U. W. Suter, F. Diederich, J. Chem. Soc.-Perkin Trans. 2 2000, 193-198.

[53] R. Deschenaux, B. Donnio, D. Guillon, New J. Chem. 2007, 31, 1064-1073.

[54] E. Terazzi, S. Suarez, S. Torelli, H. Nozary, D. Imbert, O. Mamula, J. P. Rivera, E. Guillet, J. M. Benech, G. Bernardinelli, R. Scopelliti, B. Donnio, D. Guillon, J. C. G. Bunzli, C. Piguet, Adv. Funct. Mater. 2006, 16, 157-168.

[55] T. Cardinaels, K. Driesen, T. N. Parac-Vogt, B. Heinrich, C. Bourgogne, D. Guillon, B. Donnio, K. Binnemans, Chem. Mat. 2005, 17, 6589-6598.

[56] R. W. Date, E. F. Iglesias, K. E. Rowe, J. M. Elliott, D. W. Bruce, Dalton Trans. 2003, 1914-1931.

[57] I. Aprahamian, T. Yasuda, T. Ikeda, S. Saha, W. R. Dichtel, K. Isoda, T. Kato, J. F. Stoddart, Angew. Chem.-Int. Edit. 2007, 46, 4675-4679.

[58] J. Wang, C.-G. Lin, J. Zhang, J. Wei, Y.-F. Song, J. Guo, J. Mater. Chem. C 2015, 3, 4179-4187.

[59] S. Landsmann, M. Wessig, M. Schmid, H. Coelfen, S. Polarz, Angew. Chem.-Int. Edit. 2012, 51, 5995-5999.

[60] Y. Jiang, S. Liu, J. Zhang, L. Wu, Dalton Trans. 2013, 42, 7643-7650.

[61] N. Watfa, D. Melgar, M. Haouas, F. Taulelle, A. Hijazi, D. Naoufal, J. Bonet-Avalos, S. Floquet, C. Bo, E. Cadot, J. Am. Chem. Soc. 2015, 137, 5845-5851.

[62] W. Li, S. Yi, Y. Wu, L. Wu, J. Phys. Chem. B 2006, 110, 16961-16966.

[63] W. Li, W. F. Bu, H. L. Li, L. X. Wu, M. Li, Chem. Commun. 2005, 3785-3787. 
[64] S. Yin, W. Li, J. Wang, L. Wu, J. Phys. Chem. B 2008, 112, 3983-3988.

[65] W. Li, S. Yin, J. Wang, L. Wu, Chem. Mat. 2008, 20, 514-522.

[66] S. Yin, H. Sun, Y. Yan, W. Li, L. Wu, J. Phys. Chem. B 2009, 113, 2355-2364.

[67] S. Yin, H. Sun, Y. Yan, H. Zhang, W. Li, L. Wu, J. Colloid Interface Sci. 2011, 361, 548-555.

[68] B. Li, J. Zhang, S. Wang, W. Li, L. Wu, Eur. J. Inorg. Chem. 2013, 1869-1875.

[69] Z.-J. Li, J. Zhang, X.-H. Wei, J. Cai, L.-X. Wu, Chin. J. Inorg. Chem. 2018, 34, 353-358.

[70] H. Yuan, J. Zhang, X.-H. Wei, H.-M. Fang, S.-F. Yuan, L.-X. Wu, Acta Phys.-Chim. Sin. 2017, 33, 407-412.

[71] Y. Molard, A. Ledneva, M. Amela-Cortes, V. Circu, N. G. Naumov, C. Meriadec, F. Artzner, S. Cordier, Chem. Mat. 2011, 23, 5122-5130.

[72] F. Camerel, F. Kinloch, O. Jeannin, M. Robin, S. K. Nayak, E. Jacques, K. A. Brylev, N. G. Naumov, Y. Molard, Dalton Trans. 2018, 47, 10884-10896.

[73] T. Zhang, S. Liu, D. G. Kurth, C. F. J. Faul, Adv. Funct. Mater. 2009, 19, 642-652.

[74] X. Lin, W. Li, J. Zhang, H. Sun, Y. Yan, L. Wu, Langmuir 2010, 26, 13201-13209.

[75] Y. X. Jiang, S. X. Liu, S. J. Li, J. Miao, J. Zhang, L. X. Wu, Chem. Commun. 2011, 47, 1028710289.

[76] Y. Jia, J. Zhang, Z.-M. Zhang, Q.-Y. Li, E.-B. Wang, Inorg. Chem. Commun. 2014, 43, 5-9.

[77] Y.-Q. Gao, Z.-M. Zhang, J.-Q. Shen, Y. Jia, Z.-J. Liu, E.-B. Wang, Crystengcomm 2014, 16, 67846789.

[78] J.-S. Li, X.-J. Sang, W.-L. Chen, R.-L. Zhong, Y. Lu, L.-C. Zhang, Z.-M. Su, E.-B. Wang, RSC Adv. 2015, 5, 8194-8198.

[79] C. Tan, J. Mol. Struct. 2017, 1130, 276-283.

[80] C. Tan, J. Mol. Struct. 2017, 1148, 34-39.

[81] N. Watfa, S. Floquet, E. Terazzi, W. Salomon, L. Guénée, K. L. Buchwalder, A. Hijazi, D. Naoufal, C. Piguet, E. Cadot, Inorganics 2015, 3, 246-266.

[82] S. Floquet, E. Terazzi, A. Hijazi, L. Guénée, C. Piguet, E. Cadot, New J. Chem. 2012, 36, 865868.

[83] R. Breitwieser, T. Auvray, F. Volatron, C. Salzemann, A.-T. Ngo, P.-A. Albouy, A. Proust, C. Petit, Small 2016, 12, 220-228.

[84] S. Floquet, E. Terazzi, V. S. Korenev, A. Hijazi, L. Guénée, E. Cadot, Liq. Cryst. 2014, 41, 10001007.

[85] R. Contant, A. Teze, Inorg. Chem. 1985, 24, 4610-4614.

[86] S. S. Mal, B. S. Bassil, M. Ibrahim, S. Nellutla, J. van Tol, N. S. Dalal, J. A. Fernandez, X. Lopez, J. M. Poblet, R. N. Biboum, B. Keita, U. Kortz, Inorg. Chem. 2009, 48, 11636-11645.

[87] S. S. Mal, M. H. Dickman, U. Kortz, A. M. Todea, A. Merca, H. Bogge, T. Glaser, A. Muller, S. Nellutla, N. Kaur, J. van Tol, N. S. Dalal, B. Keita, L. Nadjo, Chem.-Eur. J. 2008, 14, 1186-1195.

[88] T. Akutagawa, R. Jin, R. Tunashima, S. Noro, L. Cronin, T. Nakamura, Langmuir 2008, 24, 231238.

[89] V. S. Korenev, S. Floquet, J. Marrot, M. Haouas, I. M. Mbomekalle, F. Taulelle, M. N. Sokolov, V. P. Fedin, E. Cadot, Inorg. Chem. 2012, 51, 2349-2358.

[90] N. Watfa, S. Floquet, E. Terazzi, M. Haouas, W. Salomon, V. S. Korenev, F. Taulelle, L. Guénée, A. Hijazi, D. Naoufal, C. Piguet, E. Cadot, Soft Matter 2015, 11, 1087-1099.

[91] K. Guy, P. Ehni, S. Paofai, R. Forschner, C. Roiland, M. Amela-Cortes, S. Cordier, S. Laschat, Y. Molard, Angew. Chem.-Int. Edit. 2018, 57, 11692-11696.

[92] P. Ehni, K. Guy, M. Ebert, S. Beardsworth, K. Bader, R. Forschner, A. Buehlmeyer, N. Dumait, C. Roiland, Y. Molard, S. Laschat, Dalton Trans. 2018, 47, 14340-14351.

[93] S. Ivanova, ISRN Chemical Engineering 2014, 2014, 1-13.

[94] S. Herrmann, A. Seliverstov, C. Streb, Journal of Molecular and Engineering Materials 2014, 02, 1440001.

[95] Y. Zhou, G. Chen, Z. Long, J. Wang, RSC Adv. 2014, 4, 42092-42113.

[96] M.-Y. Wang, R. Ma, L.-N. He, Sci. China-Chem. 2016, 59, 507-516.

[97] Y. Qiao, Z. Hou, Curr. Org. Chem. 2009, 13, 1347-1365. 
[98] X. Wu, T. Huang, X. Tong, Z. Xie, W. Chen, Q. Wu, W. Yan, RSC Adv. 2015, 5, 21973-21977.

[99] A. B. Bourlinos, K. Raman, R. Herrera, Q. Zhang, L. A. Archer, E. P. Giannelis, J. Am. Chem. Soc. 2004, 126, 15358-15359.

[100] Z. P. Pai, A. G. Tolstikov, P. V. Berdnikova, G. N. Kustova, T. B. Khlebnikova, N. V. Selivanova, A. B. Shangina, V. G. Kostrovskii, Russ. Chem. Bull. 2005, 54, 1847-1854.

[101] P. G. Rickert, M. R. Antonio, M. A. Firestone, K.-A. Kubatko, T. Szreder, J. F. Wishart, M. L. Dietz, Dalton Trans. 2007, 529-531.

[102] P. G. Rickert, M. R. Antonio, M. A. Firestone, K.-A. Kubatko, T. Szreder, J. F. Wishart, M. L. Dietz, J. Phys. Chem. B 2007, 111, 4685-4692.

[103] Y. L. Wang, W. Li, L. X. Wu, Langmuir 2009, 25, 13194-13200.

[104] W. Zhu, G. Zhu, H. Li, Y. Chao, M. Zhang, D. Du, Q. Wang, Z. Zhao, Fuel Process. Technol. 2013, 106, 70-76.

[105] Y. Qiao, Z. Hou, H. Li, Y. Hu, B. Feng, X. Wang, L. Hua, Q. Huang, Green Chem. 2009, 11, 19551960.

[106] H. Li, Y. Qiao, L. Hua, Z. Hou, B. Feng, Z. Pan, Y. Hu, X. Wang, X. Zhao, Y. Yu, ChemCatChem 2010, 2, 1165-1170.

[107] T. Dong, Y.-q. Xu, F.-w. Chen, Y.-n. Chi, C.-w. Hu, Chem. Res. Chin. Univ. 2011, 27, 177-180.

[108] T. Dong, F.-w. Chen, M.-h. Cao, C.-w. Hu, Chem. Res. Chin. Univ. 2011, 27, 11-14.

[109] X. Wu, X. Tong, Q. Wu, H. Ding, W. Yan, J. Mater. Chem. A 2014, 2, 5780.

[110] Y. Leng, J. Wang, D. Zhu, X. Ren, H. Ge, L. Shen, Angew. Chem.-Int. Edit. 2009, 48, 168-171.

[111] T. Huang, Z. Xie, Q. Wu, W. Yan, Dalton Trans. 2016, 45, 3958-3963.

[112] Y. Li, X. Wu, Q. Wu, H. Ding, W. Yan, Dalton Trans. 2014, 43, 13591-13595.

[113] T. Huang, N. Tian, Q. Wu, W. Yan, Soft Matter 2015, 11, 4481-4486.

[114] X. Wu, W. Wu, Q. Wu, W. Yan, Langmuir 2017, 33, 4242-4249.

[115] X. Tong, V. Thangadurai, J. Phys. Chem. C 2015, 119, 7621-7630.

[116] L. Gharnati, O. Walter, U. Arnold, M. Doering, Eur. J. Inorg. Chem. 2011, 2756-2762.

[117] S. Herrmann, New synthetic routes to poloyoxometalate containing ionic liquids: an investigation of their properties, Springer Spektrum, Wiesbaden, 2015.

[118] S. Herrmann, M. Kostrzewa, A. Wierschem, C. Streb, Angew. Chem.-Int. Edit. 2014, 53, 1359613599.

[119] S. Herrmann, L. De Matteis, J. M. de la Fuente, S. G. Mitchell, C. Streb, Angew. Chem.-Int. Edit. 2017, 56, 1667-1670.

[120] A.-L. Kubo, L. Kremer, S. Herrmann, S. G. Mitchell, O. M. Bondarenko, A. Kahru, C. Streb, ChemPlusChem 2017, 82, 867-871.

[121] A.-L. Kubo, L. Kremer, S. Herrmann, S. G. Mitchell, O. M. Bondarenko, A. Kahru, C. Streb, Toxicology Letters 2017, 280, S193-S193.

[122] A. Misra, I. F. Castillo, D. P. Mueller, C. Gonzalez, S. Eyssautier-Chuine, A. Ziegler, J. M. de la Fuente, S. G. Mitchell, C. Streb, Angew. Chem.-Int. Edit. 2018, 57, 14926-14931.

[123] F. M. Santos, S. P. Magina, H. I. S. Nogueira, A. M. V. Cavaleiro, New J. Chem. 2016, 40, 945953.

[124] K. Shakeela, G. R. Rao, ACS Applied Nano Materials 2018, 1, 4642-4651.

[125] M. T. Pope, Heteropoly and Isopoly Oxometalates, Springer-Verlag, Berlin, 1983.

[126] D. Liu, J. Gui, F. lu, Z. Sun, Y.-K. Park, Catal. Lett. 2012, 142, 1330-1335.

[127] L. Jing, J. Shi, F. Zhang, Y. Zhong, W. Zhu, Ind. Eng. Chem. Res. 2013, 52, 10095-10104.

[128] P. Hao, M. Zhang, W. Zhang, Z. Tang, N. Luo, R. Tan, D. Yin, Catal. Sci. Technol. 2018, 8, 44634473.

[129] S. Hu, C. Ma, F. Zhan, Y. Cao, P. Hu, Q. Zhen, Chem. Pap. 2017, 71, 1323-1329.

[130] G. F. De Gregorio, R. Prado, C. Vriamont, X. Erdocia, J. Labidi, J. P. Hallett, T. Welton, ACS Sustain. Chem. Eng. 2016, 4, 6031-6036.

[131] F. Cheng, H. Wang, R. D. Rogers, ACS Sustain. Chem. Eng. 2014, 2, 2859-2865.

[132] N. Sun, X. Jiang, M. L. Maxim, A. Metlen, R. D. Rogers, ChemSusChem 2011, 4, 65-73. 
[133] M. Thierry, A. Majira, B. Pegot, L. Cezard, F. Bourdreux, G. Clement, F. Perreau, S. BoutetMercey, P. Diter, G. Vo-Thanh, C. Lapierre, P. H. Ducrot, E. Magnier, S. Baumberger, B. Cottyn, ChemSusChem 2018, 11, 439-448. 